\title{
Production potential and ecosystem quality of secondary forests recovered from agriculture - tools for landuse decisions
}

\author{
Dissertation \\ to obtain the Ph. D. degree \\ in the Faculty of Agricultural Sciences, \\ Georg-August-University Göttingen, Germany \\ By: \\ Carlos Alberto Ruiz-Garvia \\ Born in La Paz, Bolivia
}

Goettingen, July 2008 
D7

Referee: Professor. Dr. Holm Tiessen

Co-referees: PD Dr. Martin Worbes

Professor Dr. Juan Jimenez Osornio

Date of Examination: $31^{\text {st }}$ of January 2008 


\section{TABLE OF CONTENTS}

TABLE OF CONTENTS

$\begin{array}{lll}\text { LIST OF TABLES } & \text { VII }\end{array}$

LIST OF FIGURES

$\begin{array}{ll}\text { ACRONYMS AND ABBREVIATIONS } & \text { XII }\end{array}$

$\begin{array}{lr}\text { CHAPTER 1: INTRODUCTION } & 1\end{array}$

1.1 GENERAL DESCRIPTION OF FOREST AND SOILS IN

NORTHEN YUCATAN 5

Climate $\quad 5$

Soils 5

$\begin{array}{ll}\text { Land use } & 7\end{array}$

Forest of the Peninsula of Yucatan 10

Spiny deciduous low tropical forest $\quad 11$

Low deciduous tropical forest 12

Low perennial tropical forest $\quad 12$

Semi-deciduous tropical forest 13

$\begin{array}{ll}\text { Semi-perennial tropical forest } & 13\end{array}$

$\begin{array}{ll}\text { 1.2 REFERENCES } & 15\end{array}$

CHAPTER 2: ESTIMATION OF BIOMASS, CARBON AND 16 NUTRIENT STATUS OF SECONDARY FOREST

$\begin{array}{ll}\text { ABSTRACT } & 16\end{array}$

$\begin{array}{ll}2.1 \text { INTRODUCTION } & 17\end{array}$ 
Research questions: $\quad 18$

$\begin{array}{ll}\text { Hypothesis } & 19\end{array}$

2.2 MATERIAL AND METHODS 19

$\begin{array}{ll}\text { Study areas } & 19\end{array}$

Site selection and plot sampling location $\quad 21$

Soil fertility and laboratory analyses 25

$\begin{array}{ll}\text { Statistical analyses } & 28\end{array}$

$\begin{array}{ll}\text { Forest measurements } & 29\end{array}$

Nutrient pools in leaf and litter 31

2.3 RESULTS AND DISCUSSION 33

Dynamics of aboveground biomass during secondary succession $\quad 35$

Differences between black and red soils at different forest ages 46

Concentrations of elements in leaf and litter 53

Variability and consequence of land use history 60

Effects of forest age on biomass and nutrient cycling 61

2.4 CONCLUSIONS

2.5 REFERENCES 66

CHAPTER 3: GROWTH PATTERNS OF SELECTED TREE 80 SPECIES IN SECONDARY FOREST IN NORTHERN YUCATAN

$\begin{array}{ll}\text { ABSTRACT } & 80\end{array}$

$\begin{array}{ll}3.1 \text { INTRODUCTION } & 80\end{array}$ 
Objectives

Research questions

Hypotheses

Study Area

Description of Cordia dodecandra

Description of Piscidia piscipula

Tree diameter growth and growth trends of Cordia dodecandra and

Piscidia piscipula

Relation between precipitation, temperature and growth dynamics 
$\begin{array}{ll}\text { Study area } & 113\end{array}$

Experiment 1: Limiting factors in Red and Black soils for fine root 114 production

Experiment 2: Limiting factors in Red and Black soils for 116 establishment of Cordia dodecandra plantations

$\begin{array}{ll}\text { Statistical analysis } & 117\end{array}$

$\begin{array}{ll}4.3 \text { RESULTS } & 117\end{array}$

$\begin{array}{lr}\text { 4.4 CONCLUSIONS } & 121\end{array}$

$\begin{array}{lr}\text { 4.5 REFERENCES } & 122\end{array}$

$\begin{array}{lr}\text { CHAPTER 5: CONCLUSIONS } & 128\end{array}$

$\begin{array}{ll}\text { General } & 128\end{array}$

$\begin{array}{ll}\text { Implications } & 129\end{array}$

$\begin{array}{ll}\text { Identification of key areas for future research } & 131\end{array}$

$\begin{array}{ll}\text { SUMMARY } & 133\end{array}$

$\begin{array}{ll}\text { ZUSAMMENFASSUNG } & 135\end{array}$

$\begin{array}{ll}\text { ACKNOWLEDGMENTS } & 137\end{array}$

$\begin{array}{ll}\text { CURRICULUM VITAE } & 138\end{array}$ 


\section{LIST OF TABLES}

Table 2-1. Regression equations for estimating biomass of tropical trees.

Table 2-2. Density and species richness in young secondary, intermediate and mature forest

Table 2-3. Species distribution in young secondary, intermediate and mature forest.

Table 2-4. Stand density and density of most frequent species identified in young secondary, intermediate and mature forest.

Table 2-5. Aboveground biomass of trees in in young secondary, intermediate and mature forest.

Table 2-6. Biomass ( $\mathrm{Mg} / \mathrm{ha})$ in young secondary, intermediate and mature forest.

Table 3-1. Dendro-cores collected at different succession stage.

Table 4-1. Fertilization Effects on Fine Root Production.

Table 4-2. Multiple range analysis of seedling growth at the end of six months. 


\section{LIST OF FIGURES}

Fig 2-1. Different landuses in Semiarid Ecosystems; Henequen plantations and young secondary Forest vegetation.

Fig 2-2. Plot design for collection of soil and vegetation samples.

Fig 2-3. Plot design for collection of litter samples (5 plots with 3 repetitions).

Fig 2-4. Methodology considered for soil analysis.

Fig 2-5. Methodology considered for leaves and litter analysis.

Fig 2-6. Basal area, Volume and Density of young secondary, intermediate and mature forest.

Fig 2-7. Species abundance. in young secondary, intermediate and mature 39 forest. Only trees with $\mathrm{Dbh}>8 \mathrm{~cm}$.

Fig 2-8. Species abundance. in young secondary, intermediate and mature forest. Only trees with $\mathrm{Dbh}<8 \mathrm{~cm}$.

Fig 2-9. Frequency of young secondary, intermediate and mature forest.

Fig 2-10. Total Height (m) predictions to the Dbh.

Fig 2-11. Mean Total Height (m) of some tree species at different 42 succession stages.

Fig 2-12. Biomass of most frequency species in young secondary, 
intermediate and mature forest.

Figure 2-13. Significant differences between N-black and N-red soils.

Figure 2-14. Significant differences between C-black and C-red at different forest age.

Figure 2-15. Significant differences between N-black and N-red soils at different forest age.

Figure 2-16. Significant differences between CE K-black and CE K-red 51 soils at different forest age.

Figure 2-17. Significant differences between CE Mg-black and CE Mgred soils at different forest age.

Figure 2-18. Significant differences between CE Ca-black and CE Cared soils at different forest age.

Figure 2-19. Significant differences between $\mathrm{K}: \mathrm{Mg}: \mathrm{Ca}$ ratios in black and red soils.

Fig 2-20. Litter and small branches at sampling time at different forest age classes.

Figure 2-21. Significant differences between N-litter, N-leaf and N litter and leaf ratio. 
Fig 2-22. $\mathrm{K}(\mathrm{mg} / \mathrm{g})$ in leaf and litter at different forest age.

Fig 2-23. $\mathrm{Mg}(\mathrm{mg} / \mathrm{g})$ in leaf and litter at different forest age.

Fig 2-24. Ca (mg/g) in leaf and litter at different forest age.

Figure 3-1. $30 \mathrm{~cm}$-Suunto increment borer utilized to collect core sample from selected trees.

Figure 3-2. Wooden supports and stem discs used for tree ring analysis.

Fig 3-3. Wood anatomy and physiology of selected tree species: Cordia dodecandra and Piscidia piscipula

Fig 3-4. Applied methodology to estimate growth patterns of two selected tree species in Northern Yucatan.

Figure 3-5. Dbh growth rate $(\mathrm{cm})$ obtained through tree ring analysis for core-samples of Cordia dodecandra.

Figure 3-6. Dbh growth rate $(\mathrm{cm})$ obtained through tree ring analysis for core-samples of Piscidia piscipula

Figure 3-7. Comparison of $\mathrm{dbh}$ growth rate $(\mathrm{cm})$ obtained through tree ring analysis for core-samples of Piscidia piscipula and Cordia dodecandra.

Figure 3-8. Fitted diameter curves of Piscidia piscipula. 
Figure 3-9 Total Height $(\mathrm{m})$ curve to the dbh $(\mathrm{cm})$.

Figure 3-10. Correlation between tree-ring width indices of Piscidia 101 piscipula and precipitation. The parallel variation value (Glk.-value, Rinn, F (1996): Worbes et al (1999)) as a measure for the similarity of a tree ring series was high over $67 \%$.

Figure 3-11. Correlation between tree-ring width indices of Piscidia piscipula and temperature. The parallel variation value (Glk.-value, Rinn, F (1996): Worbes et. al (1999)) as a measure for the similarity of two tree ring series, was lower than $60 \%$.

Figure 4-1. Experiment design applied in the ingrowth cylinder 118 experiment.

Figure 4-2. Experiment design applied in the Cordia sp. experiment.

Fig 4-3. Accumulation rates of fine root biomass, in black soils, secondary of the Semiarid Americas.

Fig 4-4. Accumulation rates of height increment, in black soils, in Cordia dodecandra plantations, in the Semiarid Americas. 


\section{ACRONYMS AND ABBREVIATIONS}

\begin{tabular}{|c|c|}
\hline $\mathbf{A A S}$ & Atomic absorption spectrometry \\
\hline ANOVA & Analysis of variance \\
\hline CONABIO & Comisión Nacional para el Conocimiento y Uso de la Biodiversidad \\
\hline CONAFOR & Comisión Nacional Forestal \\
\hline dbh & Diameter at breast height \\
\hline df & Degree of freedom \\
\hline EEV & Equality of error variances \\
\hline EM & Ectomycorrhizal \\
\hline expl. & Explanations \\
\hline FAO & World Food and Agriculture Organization of the United Nations \\
\hline fert. & Complete fertilizer treatment \\
\hline GmbH & $\begin{array}{l}\text { Abbreviation used in the name of German companies that are legally } \\
\text { established }\end{array}$ \\
\hline IAI & Inter-American Institute for Climate Change Research \\
\hline INEGI & Instituto Nacional de Estadística Geografía e Informática \\
\hline IAT & Institute of Agronomy in the Tropics \\
\hline ICRAF & World Agroforestry Centre \\
\hline Inc. & $\begin{array}{l}\text { Abbreviation for Incorporated, used in the name of U.S. companies that are } \\
\text { legally established }\end{array}$ \\
\hline $\mathbf{L}$ & Liter \\
\hline $\max$ & Maximum \\
\hline $\min$ & Minimum \\
\hline NS & Non-significant \\
\hline \multirow[t]{2}{*}{ Protrópico } & Departamento de Manejo y Conservación de Recursos Naturales \\
\hline & Tropicales \\
\hline SE & Standard error \\
\hline seedl. & Seedling \\
\hline SIRE & Sistema Nacional para la Reforestación en México \\
\hline
\end{tabular}


SPFEQROO Sociedad de Productores Forestales Ejidales en Quintana Roo

Statistics Inc. Software for statistical analysis of data and name of the producer company

sti

UADY

UNAM

UNESCO

VA

VAM

VAMF

vdi

WHO
Stem length increment

Universidad Autónoma de Yucatán

Universidad Nacional Autónoma de México

United Nations Educational, Scientific, and Cultural Organization

Vesicular arbuscular

Vesicular arbuscular mycorrhizal

Vesicular arbuscular mycorrhizal fungi

Virtual diameter increment

World Health Organization of the United Nations 


\section{CHAPTER 1: INTRODUCTION}

The area covered by secondary forests in the Tropics is estimated by Brown and Lugo (1990) to be more than 600 million ha. This is equivalent to roughly $35 \%$ of the total forest area in the Tropics.

The debate on secondary forests increases in importance as the decrease in area of primary forests continues. Many secondary forests are being used intensively and in a more or less systematic and permanent way, especially in the proximity of human settlements for local consumption, and to a lesser extent for sale. A large part of secondary forests is part of a continual use cycle in which forest clearings for agriculture is followed by forest regeneration aimed at regaining soil productivity (shifting cultivation). High exploitation pressure means that the danger of over-exploitation is often very real. Current use includes wood (timber and fuel), non-timber forest products, forest fallow (for the regeneration of the area) and forest pasture. The biggest economic importance of secondary forests lies in their fuelwood production and in their role as forest fallow in the cycle of shifting cultivation.

In tropical regions, the principal landuse change is the conversion of forests into agricultural land and the continuing cycles of shifting cultivation. Tiessen et al. (1992) reported that land under shifting cultivation in the semi arid-NE Brazil usually sustains about 5 years of cropping, during which yields decline until farming is uneconomical and the land is abandoned to regrowth of secondary vegetation. During this bush fallow, fertility levels are improved and the land may become available for further cultivation cycles (Tiessen et al. 1992). Increasing land scarcity results in reduced fallow periods. Fertilization is commonly neither economical nor available to subsistence farmers in semi-arid environments where crop production is severely limited by moisture availability.

Successful utilization concepts are available for multi-purpose use of secondary forests with agro-forestry and silvopastoral elements. These are often a further development of 
traditional systems. One example is the systematic encouragement of certain tree species (for timber, fruit, oil, etc.) during the fallow period whilst at the same time cultivating agricultural plants (like coffee or pasture) in the lower story.

Secondary forest plays a vital role in the maintenance of land quality. Secondary forests and fallows are also important for the community. Tiessen et al. (1998) reported that fire wood from secondary forests accounts for $30 \%$ of the energy supply and $14 \%$ of the rural income in NE Brazil. Between 0.5 and $1 \%$ of NE Brazil are cleared yearly for firewood production with a regeneration cycle of about $13 \mathrm{y}$, this involves $10-20 \%$ of the region. Ruiz et al. (2003) have shown that in a plantation of Serebo (Schizolobium amazonicum), that produces timber and considers credits for carbon sequestration; the net income is higher than the net income from grazing in the region of Buena Vista - Bolivia. Ecosystem services and forest productivity may stimulate land users to convert to forests, but the benefits and sustainability of conversion into forest is still not well documented and understood by land use decision makers.

For Latin America, $370 \times 10^{6}$ ha (range $313-412 \times 10^{6}$ ha) of forest were replaced by some other ecosystem over the period 1850-1985 (Houghton et al. 1991). This area is 28\% of the forest area in $1850 ; 44 \%$ of the $370 \times 10^{6}$ ha has been converted to pastures, $25 \%$ to croplands, $10 \%$ is degraded land, and shifting cultivation accounts for $10 \%$. The rate of conversion of forest to managed lands in Latin America was $5.6 \times 10^{6}$ ha in 1980 , increasing to $6.6 \times 10^{6}$ ha in 1985 (Houghton et al., 1991).

During last decades the Yucatan peninsula has undergone increasing land use change, ranging from selective logging to widespread shifting cultivation agriculture to land clearing for intensive agriculture and village establishment (Lawrence and Foster, 2002).

The increasing population density and limited land allocation has forced farmers of Mayan heritage in small villages to shorten fallow periods, creating areas of young vegetation and practically eliminating old forests. This also has important implications for the viability of farming, as shorter fallows reduce nutrient availability and increase the burden of weeds. Consequently, the Yucatan dry forests have been extensively cleared 
for agricultural and cattle farming pressures. Many square kilometers of dry forest have been substituted either by Sisal plantations, or by secondary communities that arise from intense cattle grazing (CICY 1993). In particular, in Northern Yucatan, huge areas of abandoned sisal plantations, now assigned to the communities, require management strategies that take into account the high spatial variability of soil, the lack of surface water, and the generation of income for farmers. However, soil fertility studies in this ecosystem are limited and mainly focused on the decline of soil fertility by cropping, but most of them present analytical problems and the quality of data is negatively influenced by the high heterogeneity of the soils (Weisbach et al., 2002; Lawrence and Foster, 2002).

The assessment of the nutritional conditions of these soils may contribute to improve soil management. Suitable and sensitive techniques, which combine the influence of climatic factors and biochemical processes in the soil, permit a better understanding of these semiarid ecosystems.

On the other hand, total benefits of ecosystem services provided by forest fallows and the potential for forest production have not been evaluated, largely because forest productivity under secondary land cover has rarely been measured with an eye to marketable products. Even the important production of fuel wood is often based more on market than on ecosystem observation. Sustainable management systems, rates of natural regeneration, the role of enrichment planting or improved fallows, and the forestry potential of agroforestry practices are only beginning to be explored. Recent advances in tropical tree ring analysis (Worbes, 2002) make it possible to evaluate growth rates, optimum production periods and timber quality of regenerating forests.

Combining the study of ecosystem benefits with an evaluation of production potential will provide a basis for deciding between land uses: agriculture/grazing, forest, or a combination such as agroforestry within which forest products can provide income rather than just ecosystem services. Land-use change has had a major impact on terrestrial $\mathrm{C}$ losses. Conversions of abandoned agricultural lands and pastures into forests may have 
beneficial effects for the atmosphere, ecosystems (water, soil, biodiversity) and socioeconomic well-being (Ruiz et al. 2003).

This study explored options for improved landuse management in secondary forest. One of the primary objectives was to understand the effects of succession time (i.e., time since abandonment) on accumulations of aboveground biomass and elements in secondary forests of the Northern Yucatan Peninsula, and, to quantify the degree to which secondary forests may act as $\mathrm{C}$ and nutrient sinks. To do this, we quantified total aboveground biomass as well as pools of total $\mathrm{C}, \mathrm{N}, \mathrm{S}, \mathrm{Ca}, \mathrm{K}$ and $\mathrm{Mg}$ in mineral soils. We also quantified $\mathrm{N}, \mathrm{S}$, and $\mathrm{K}$ in leaves and litter at secondary forest sites that ranged in age from 1 to $50 \mathrm{yr}$. We then used this secondary forest chronosequence to quantify potential rates of aboveground biomass and mineral soil pool accumulation, to document changes in partitioning of aboveground biomass and elemental pools between structural components through time, and to evaluate the influence of site age on accumulation rates.

Two selected species were studied in terms of growth patterns and timber and firewood production potential. Production potential were evaluated using tree ring analysis from samples collected at each site, samples collected in home gardens and a set of samples available at CRN001 that were collected for the project in 2002.

Trials using in-growth cylinder determine nutrient limitations on tree fine root systems that may be a cause for low growth rates in secondary vegetation.

This study of forested ecosystems evaluates the productivity and utility of different secondary land cover types derived from agricultural activities (Sisal plantations; Agave fourcroydes Lem) and relates this to the productivity of a natural protected forest in climatically vulnerable subhumid and semiarid regions of the Americas. The emphasis on productivity and utility of the treed components of land cover in relation to agricultural alternatives implies the documentation of human dimensions and decision processes of land cover and land use change. A specific contribution of the study is to provide 
information for decision making regarding the reconversion (or not) of agricultural lands to different types of tree production.

\subsection{General description of forest and soils in Northern Yucatan}

\section{Climate}

The Yucatan peninsula, in southeastern Mexico, is south of the Tropic of Cancer. As in other subtropical forests, there is a long dry season that is responsible for the deciduous nature of the forests. Annual precipitation ranges from 500-1500 mm (Benjamin, 2000), with the lower values in the North-West coast of the peninsula and values above 1200 $\mathrm{mm}$ in the South-East (Duch, 1988). The mean annual rainfall is $983 \mathrm{~mm}$ with high variability due to the presence of tropical storms and hurricanes during the wet season and also to Northwinds causing scattered rainfalls during the dry season. Temperature in some months may reach more than $40{ }^{\circ} \mathrm{C}$ (Benjamin, 2000). The annual mean temperature is $26^{\circ} \mathrm{C}$.

The climate is hot subhumid with summer rainfalls. There are two thermal conditions, hot from April to October and cool (called winter) from December to February. March and November are considered transitional months. However, $75 \%$ of the total falls during the rainy-season from May to October and the rest of the year is considered dry. A middle summer drought for a short period - a phenomenon called canícula - is characteristic of Yucatan's climate and is of importance for agricultural practices. According to Koeppen the dominant climate in the study area is Awo which is the driest of the semi-arid climates.

\section{Soils}

The Yucatecan soils are formed from tertiary limestone on a typical karstic landscape of flat rocks outcrops and shallow depressions, giving a mosaic of black lithosols, which occur mainly on slightly elevated areas $(<0.5 \mathrm{~m})$, and red rendzinas, which occur in 
depressions and are deeper $(>20 \mathrm{~cm})$ with a low gravel content. The differences in depth, stone content and high calcium carbonate content are closely related to their chemical properties (Weisbach et al., 2002: Aguilera, 2007).

The knowledge on nutrient requirements of tropical dry forest in Northern Yucatan is still scarce. Weisbach et al., 2002 reported that the crop productivity decline was attributed to interactions between $\mathrm{P}$ and $\mathrm{K}$ supply and available water.

Reuter (2005) cited to Becker and Asch (2004) who reported that nutrient stocks in the dry tropics are high; their availability is low and the melioration of these soils difficult. Major limits to nutrient availability for plants are drought and on calcareous substrate sorption of essential nutrients. Red soils present lower content of all nutrients, indicating a more advance development (Weisbach et al., 2002).

Total soil carbon and nitrogen are very high in Yucatecan soils (Benjamin, 2000; Weisbach et al., 2002). Soil organic matter in Yucatecan forests averaged over 20\%, which is higher than values $(0.5$ to $5 \%)$ for other tropical regions, and also $\mathrm{N}$ and $\mathrm{P}$ are much higher than those of other tropical dry forests (Ceccon et al., 2002). Weisbach et al. (2002) reported higher $\mathrm{C}$ and $\mathrm{N}$ content, and also a much greater accretion of soil organic matter in black soils, about twice that in red soils, even when both soils were under similar plant residue inputs explaining that this can be caused by a delayed decomposition of the plant residues or its concentration in the thin soil layer of the black soils. Higher organic matter content in black soils has been also reported by Bautista et al. (2003). These soils also differ in carbonate content, effective cation exchange capacity, primary $\mathrm{P}$ mineral and total $\mathrm{P}$ content.

Red and black soils represent different challenges to farmers. On deeper red soils, weeds tend to develop very fast. Seed germination rate is higher on red soils than on black soils on terrain elevations. Black soils only provide a limited area for planting, due to their high rocky- and stoniness. Different soils are preferred for specific crops. On black soils and shallow red soils, typical crops are Zea mays, Phaseolus species, and Cucurbita 
species. Due to the absence of rocks and stones, deeper red soils are chosen for a variety of other crops such as cassava (Manihot esculenta) (Estrada Medina, 2000; Reuter, 2005). There is little knowledge on preferred tree species for different soil types, as there is not much practice of tree planting in the Northern Peninsula. Farmers from the community Hocaba mentioned Bursera simarouba and Piscidia piscipula as tree species that grow fast on red soils (Estrada Medina, 2000). Latin-American Cedar (Cedrela odorata) was recommended by foresters of the State of Yucatan as a species apt for establishment on stony Leptosol (CONAFOR, 2003; Reuter et al., 1998).

\section{Land use}

The most common method of clearing the land is slash and burn and the main land uses are shifting cultivation, home gardens livestock production and Sisal plantations.

Sisal (Agave fourcroydes), a native agave, has been cultivated in semiarid regionas by the Maya since the pre-Colombian period. It became the most important economic activity of the tropical and subtropical Americas during last century (Mizrahi et al., 1996). 50\% of the economically active population was employed in sisal cultivation (Mizrahi et al., 1996; De Teresa, 1992). Sisal requires several years of growth before it matures to a productive stage, thus it was normally cultivated as part of a complex agricultural system. Normally, a forest area was cleared, and the Sisal was panted in conjunction with slashand-burn agriculture, which continued for 2 or 3 years while the Sisal matured. After that period, the land was left to Sisal. This pattern of cultivation resulted in a mosaic landscape comprising forest, Sisal, and slash-and-burn agriculture with Sisal. Today, mature forest is practically non-existing.

The international demand for Sisal fiber was greatly reduced in the 60 s when synthetic fibers were develop (Mizrahi et al., 1996; Sanders, 1997). Sisal production in semiarid regions finally collapsed in 1992 when the governments stopped subsidizing its production. As a result of the continuing decline of Sisal production, plantations were abandoned converting these areas in secondary forest with unknown economic value. 
Other traditional land use practice is corn production (so-called milpa), a slash-and-burn cultivation shifting cycle. Zea mays (corn) is combined with other crops such as pumpkin (Cucurbita species), beans (Phaseolus species), and tropical chickpea (Vigna unguiculata L.) (Hernández Xolocotzi et al., 1995). At least 17 years of fallow are necessary for regeneration of the soil after one to tree years of crop production (Aguilera, 2007). Due to increasing pressure on the land, the fallow period is shortened (Weisbach et al, 2001). This leads to a decline in productivity, in addition to the loss of organic material and the volatilization due to burning. In the former sisal production zone, corn yields of 700 and $500 \mathrm{~kg} / \mathrm{ha}$ for the first and second year after burning was reported. The stoniness of the soil makes the use of conventional agricultural machinery impossible (Arias, 1995).

Milpa has historically been sustainable for long periods, and could continue to be, as long as fallow times are sufficient. In many tropical regions that practice slash and burn agriculture, reduced fallow periods occur due to increasing population. This is also true of Yucatan, however it is not the whole story. A key factor affecting Milpa was the change in settlement patterns in the post-Columbian era, with a formerly even distribution of people encouraged to congregate around convents and churches. This trend continues today, and high population densities are thus a localized problem, rather than a problem that affects all areas. In addition, in the pre-Columbian era all land was essentially communal. Now land tenure is more complex, consisting of a mixture of private property, national lands, communal lands and co-operative ejido land. As a consequence milpa practicioners are more restricted in their land choice.

Milpa is a complex gardening polyculture. Since pre-Columbian times, an assortment of agricultural and forestry systems have been used and adapted by Mayan settlements throughout the peninsula. Most of the areas need fallow periods between 15 and 25 years for restoration of soil fertility, but increasing population, changes in land tenure, and limited allocation has reduced fallow periods from around 20 years to less than 7 , threatening the sustainability of the milpa ecosystems (Moya et al., 2003; Benjamin, 2000; and Weisbach et al., 2002). 
Today, there is much less land dedicated to Milpa than during the pre-Columbian era, for a number of reasons. As already mentioned, the Spanish colonizers encouraged the concentration of settlements, and this trend continues, with the emigration of men to cities to seek off-farm work. Another reason for the reduced areas available for Milpa, is the conversion of land to cattle production in the east of the peninsula. Many interrelated factors threaten the future of Milpa. As the decline continues, there is concern that as the younger generation seeks livelihoods in cities and towns; traditional agricultural knowledge is being lost. In addition, for a variety of reasons, Milpa is not supported by current local, state or national governments.

The name 'slash and burn' evokes images of forest destruction, uncontrolled cattle grazing and loss of biodiversity. The State Government of Yucatan has recently broadcast radio messages discouraging burning of forests. However, such policies have not hindered the farmers, who have little alternative but to continue what they have been doing for hundreds of years (Moya et al., 2003).

Homegardens have been also important to Maya cultivation for centuries. Nowadays, in the Maya villages in Yucatan, houses are surrounded by homegardens that mimic a complex structure of a mature forest with plants growing in multiple strata, and often, animals for household use. This ecosystem has been shown to be a productive use of the areas that surround people's houses, providing fruits and vegetables for household consumption and also, for sale at a market (Benjamin, 2000). The constant inputs of resources in form of food, manure, soil from the secondary forest, and human dwellings, and also, water management enrich the system as a site for plant growth. For this reason, Yucatecan homegardens could be described as a trap of nutrients (Andrist, 2003; Parsons, 2007).

Reported average maize yields of approximately $750 \mathrm{~kg} / \mathrm{ha}$ are significantly below the national average yield of $2 \mathrm{t} / \mathrm{ha}$ (INEGI, 1992). Weed infestation is also reported to be common, resulting in increased chemical use and consequent reduction in companion planting of squash and beans. The photo below shows the interaction between shortening 
fallow period and weed infestation. It is evident from the height of the surrounding forest that the fallow period was not sufficient. The consequent high incidence of weeds will likely impact crop yields, even if a large amount of labor is used to attempt to control them. Reduction in corn yields, leads to increased areas needed for production, resulting in a positive feedback of forest use.

\section{Forest of the Peninsula of Yucatan}

There is a gradient of increasing precipitation from north to south across the Yucatán Peninsula with consequent changes in vegetation types. Most of the Peninsula is covered by tropical forests that are differentiated by a variable proportion of deciduous species (Flores and Espejel, 1994). The following summary describes the most prominent vegetation types and their respective species composition in Yucatán.

The landscape is dominated by limestone bedrock found underneath a shallow soil surface layer, the lack of surface water and the presence of underground caves and rivers, but also sinkholes or cenotes, which are formed when limestone shelf collapses due to the dissolving process and expose the water below, throughout the peninsula (Benjamin, 2000; Aguilera, 2007).

The native vegetation is a deciduous dry forest with a maximal height of about 25 meters. The forests grow on a vast portion of flat terrain $(<400 \mathrm{~m}$ above sea level), composed of limestone of coraline origin. Soils are generally young and of calcareous origin; and drainage is extensive, thus the soils hardly ever flood (CICY, 1993). Dominant vegetative species in the central portion of the region are: tsalam (Lysiloma bahamensis) and jabín (Piscidia piscipula), and can be accompanied by Alvaradoa amorphoides, Bursera simaruba, Cedrela mexicana, Chlorophora tinctoria, Cordia gerascanthus and Lonchocarpus xuul in other areas. The accompanying species are Vitex gaumeri, Brosimum alicastrum, Caesalpinia gaumeri, Cedrela odorata, Ceiba pentandra and Sideroxylon fuetidissimum. In the northern part of the ecoregion, near the coast, cacti become more abundant. Common cactus species include: Cephalocereus gaumeri, 
Pterocereus gaumeri and Lemaireocereus griseus. Herbaceous plants, epiphytes and fungi are rather scarce, but bromeliads like Tillandsia do grow on some trees.

The forest cover of the Yucatan Peninsula is dominated by forests with dominant trees of the upper stratum of more than $15 \mathrm{~m}$ of height (selva mediana). In the Northern part of the Peninsula, deciduous forests of 10 to $15 \mathrm{~m}$ height are primarily found, with dominant native tree species such as Kitamche (Caesalpinia gaumeri) and Jabin ( $P$. piscipula) (Pennington and Sarukhan, 1998; Flores and Gerez, 1994). In the Northern part of the State of Yucatan, in areas of low precipitation, low deciduous thorny tropical forests with Cactaceae (Nopalea cohenellifera) and Leguminosae families (Acacia pennatula, Acacia cornigera) are found (forest classification according Miranda, 1958; Flores and Gerez, 1994). A major commercial tree species known to be adapted to the climate and soil conditions is Latin-American Cedar (C. odorata). In a 12-year-old stand in dry tropical secondary vegetation on abandoned Henequén plantations, fast-growing Cordia alliodora had the highest seedling density (Mizrahi Perkulis et al., 1997). The well-known tree species of high commercial value of the medium sub-evergreen forests of the Southern Peninsula is Mahogany (S. macrophylla). A wide range of lesser-known tree species with valuable timber such as C. dodecandra accompanies it (Pennington and Sarukhan, 1998; Reuter et al., 1998; Flores and Gerez, 1994).

\section{Spiny Deciduous Low Tropical Forest}

This type of vegetation covers an area of $1450 \mathrm{~km}^{2}$ along the northern coast of the state of Yucatan and the northern section of Quintana Roo. It has a dry warm climate with summer rains and a mean annual temperature of $26^{\circ} \mathrm{C}$. This tropical forest typifies the state of Yucatan and the north of Campeche with a prevalence of trees from the Leguminosae family. This type of tropical forest is ecologically very important because it has endemic species in danger of extinction. One specific case is Mamillaria goumeri. The height of the trees varies between $3-8 \mathrm{~m}$, with normal diameters $<20 \mathrm{~cm}$. The most common tree species of these forests are: Acacia pennatula, A. farnesiana, A. gaumeri, A. cornigera, A. collinsi, Mimosa bahamensis, Pithecellobium albicans and Bursera 
simaruba. The herbaceous stratum has a prevalence of Agave angustifolia, Morinda yucatense, Senna occidentales, Dalergia gabra, Sida acuta and Ipomea carnea.. This type of vegetation community has undergone considerable disturbance due to changes in the land use for urbanization, agricultural establishment and cattle grazing.

\section{Low Deciduous Tropical Forest}

This plant community abounds in Yucatan occupying the area north of Campeche and covering an area of 19,839 $\mathrm{km}^{2}$. The height of the trees varies between 6 and $15 \mathrm{~m}$, and the diameter at breast height is from $10-30 \mathrm{~cm}$. This forest is characterized as deciduous because all the trees shed their leaves in the dry season of the year (February - May). There are two dominant strata in this plant community: the arboreal and the herbaceous which has woody deciduous lianas from the Bignomiaceae, Laeguminosae and Cobretaceae families. The dominant species are: Jatropha gaumeri, Metopium brownei, Alvaradoa amorphoides, Bursera simaruba, Maclura tintoria, Bumelia retusa, Mimosa bahamensis, Caesalpinia gaumeri, Guazuma ulmifolia, and Diaspyros cuneata. This type of vegetation has been modified by the development of Sisal (Agave sp.) plantations and by harvesting for fuel.

\section{Low Perennial Tropical forest}

This type is poorly represented at the Yucatan peninsula and it is restricted to small patches north of Campeche, Yucatan and Quintana Roo, where it covers an area of 806 $\mathrm{km}^{2}$. The higher stratum of this community is constituted by trees up to $7 \mathrm{~m} \mathrm{high,} 50 \%$ of which lose their leaves in the dry season. The dominant trees of this community are Haematoxylum campechanum (the "palo tinto" tree, characteristic of this community), Bucida burceras, Metopium brownei, Cameraria latifolia and Pachira acuatica. Less frequently one finds Byrsonima crassifolia, Manilkara zapota, Jatropha gaumeri, Chrysophyllum mexicanum, Coccoloba cozumelensis, Croton sp., Psidium sartorium, and, Cordia dodecandra. 


\section{Semi-deciduous Tropical forest}

This community is found mainly in the state of Yucatan as a wide band across the central part of the state, continuing north until Campeche and Quintana Roo. Its total area is of $29,309 \mathrm{~km}^{2}$. It occurs in areas with semi-humid warm climates with summer rains. The height of the trees in this community varies between 10 and $20 \mathrm{~m}$. From 50 to $75 \%$ of the trees in this community shed their leaves. Dominant species are: Acacia pennatula, Caesalpinia goumari, Caesalpinia platylaba, Lysiloma latisiliquum, Enterolobium cyclocarpum, Mimosa bahamensis, Pithececellobium dulce, P. albicans, Cedrela mexicana and Bursera simaruba. This community is poorly represented in the peninsula, as it has been displaced by human settlements and most of dominant trees are cut before they reach their full height.

\section{Semi-perennial Tropical forest}

This is the largest community and covers approximately $60 \%$ of the peninsula. It comprises most of Quintana Roo, three quarters of Campeche and a small portion of Yucatan. This type of vegetation develops in areas averaging $1300 \mathrm{~mm}$ annual rainfall where, even in the driest season, the precipitation reaches almost $200 \mathrm{~mm}$. Here, $25 \%$ of the trees shed their leaves in the dry season and reach heights of 25 to $35 \mathrm{~m}$. The dominant trees are Manilkara zapota (chicozapote or chicle), Vides gaumeri, Lysiloma latisiliquum, Brosimum alicastrum, Swietenia macrophylla (mahogany, dominating species at Quintana Roo and Campeche) Bucida buceras, Pimenta dioica, Alseis yucatenses and Chlorophora tinctorea. Changes in landuse (felling and clearing the land for cattle raising, cultivation or human settlements), fires and natural phenomena like hurricanes, have affected thousands of hectares of this forest type in the last decade.

Other vegetation types of the Yucatan Peninsula, close to the boundary or lying outside of the Yucatan state are the High Semi-perennial Tropical forest, the High Perennial Tropical forest, and the pine forest. The first is a forest in areas with $>1800 \mathrm{~mm}$ precipitation and formed by trees between $25-35 \mathrm{~m}$ tall, with $25 \%$ to $50 \%$ of these trees 
shedding their leaves in the dry season of the year. Species found in these forests include Brosimum alicastrum, Manilkara sapota, Swietenia macrophylla, Bucida buceras, Calocarpum mamosum, Andira inermes, Simarouba glauca, Cedrela mexicana, Ceiba pentandra, Senna alata, Pimenta dioica and, Cordia alliodora. This community has been extensively disturbed by cattle ranching. The High Perennial Tropical forest is common at the southeast of Campeche, in the Guatemala frontier. There the climate is humid and warm, with $2000 \mathrm{~mm}$ annual precipitation and three months of drought. Trees can be 30 $\mathrm{m}$ tall. The dominant trees are: Alseis yucatenses, Bucida buceras, Brosimum alicastrum, Callophyllum brasilensis, Dialum guianensis, Pithecellobium leucospermum, Swietenia macrophylla, Zuelania guidonia, Ceiba pentandra, Manilkara sapota and Ficus acotinifolia. Only small relict pockets of this community remain, as it has been extensively modified for highly-prized timber extraction and for cattle development, particularly in Campeche. The Pine forest is an association of Pinus caribea mixed with savanna elements. It is a unique community in the peninsula and only found in a small area of $0.006 \mathrm{~km}^{2}$, at the state of Quintana Roo. The annual precipitation in the area is $1230 \mathrm{~mm}$ with a mean annual temperature of $26^{\circ} \mathrm{C}$. The pine population is surrounded by low semi-humid tropical forest and mean perennial tropical forest, dominated by "caobas" (mahogany tree) Swietenia macrophylla, Bactris balanoides and Desmoncus ferreos. Although the dominant natural vegetation of this area is quite varied only small relicts of the original vegetation can be found today. This is the result of overexploitation of the highly prized timber, changes in the use of the land, urbanization, intentional fires, hurricanes, etc. The sites with climax vegetation have practically disappeared from the peninsula and in many places there is only secondary vegetation. 


\subsection{REFERENCES}

Challenger, A. 1998. Utilización y conservación de los ecosistemas terrestres de México. Pasado, presente y futuro. Conabio, IBUNAM y Agrupación Sierra Madre, México.

CICY. 1993. Jardín Botánico Regional. Guía General. Yucatán, México: Centro de Investigaciones Científicas de Yucatán, A.C.

CONABIO Workshop, 17-16 September. 1996. Informe de Resultados del Taller de Ecoregionalización para la Conservación de México.

CONABIO Workshop, Mexico, D.F., November. 1997. Ecological and Biogeographical Regionalization of Mexico..

Estrada-Loera, E. 1991. Phytogeographic relationships of the Yucatán Peninsula. Journal of Biogeography 18: 687-697.

Flores-Villela, O. 1993. Herpetofauna de México: distribución y endemismo. Pages 251279 in T. P. Ramamoorthy, R. Bye, A. Lot, y J. Fa, editors, Diversidad Biológica de México. Orígenes y Distribución. Instituto de Biología, UNAM, Mexico.

INEGI Map. 1996. Comision Nacional Para el Conocimiento y Uso de la Biodiversidad (CONABIO) habitat and land use classification database derived from ground truthed remote sensing data Insitituto Nacional de Estastica, Geografia, e Informática (INEGI). Map at a scale of 1:1,000,000.

Rzedowski, J. 1978. Vegetación de Mexico. Editorial Limusa. Mexico, D.F., Mexico. 


\section{CHAPTER 2: ESTIMATION OF BIOMASS, CARBON AND NUTRIENT STATUS OF SECONDARY FOREST}

\subsection{ABSTRACT}

This study evaluates the productivity of forest fallows derived from agricultural activities (Sisal plantations; Agave fourcroydes Lem) in a climatically vulnerable semiarid region in Northern Yucatan. Secondary forests ranging in age from 1 to 50 years were measured on a total of 18 plots of $1000 \mathrm{~m}^{2}$ each. Total height, stem density, basal area, and species number were calculated at the stand level. Species diversity was calculated for each succession stage. A correspondence analysis was performed, and the relationship between relative abundance of the species and stand age was modeled using a set of hierarchical models. We quantified total aboveground biomass as well as Pools of $C, N, S, C a, K$ and $M g$ in mineral soils. In our study, total and organic carbon (TC and OC), as well as total nitrogen (N) were measured by dry combustion. Prior to OC determination, carbonates were removed by acid treatment with HCl by the methodology described by Echenique (2005). Exchangeable cations $\mathrm{K}, \mathrm{Mg}$ and Ca were also determined. We quantified $\mathrm{N}, \mathrm{S}$, and $\mathrm{K}$ in leaves and litter at secondary forest sites that varied with regard to age (i.e., from 1 to $50 \mathrm{yr}$ ).

Our results showed that the total height and basal area increased with stand age, indicating that secondary forests rapidly attain a forest structure similar to mature forests after 35 years. A total of 48 species were recorded of which 50 percent made up 83 percent of the sampled individuals. The results of the correspondence analysis indicated that species composition varies with stand age. Species showed different patterns of abundance in relation to stand age, supporting the current model of succession. Litter production increased consistently with age. Interaction between the forest age and soil type was a determining factor for OC and total $N$ contents in these ecosystems. Red soils had less $O C$ and $N$ compared to the black ones. These differences between both soils were strongly marked by their mineralogical properties. The low levels of exchangeable $K$ may be a limiting factor in these calcareous soils.

Keywords: Forest succession, secondary forest, biomass, calcareous soil, semiarid tropic. 


\subsection{INTRODUCTION}

Growing prevalence of secondary forests in tropical regions and their potential importance to the economy of local communities and to global carbon and nutrient cycles, an understanding of their development and functioning is needed since they are rapidly becoming a common land cover type in tropical and subtropical regions of the world. It has been estimated that approximately $9 \times 10^{6}$ ha of secondary forests are formed annually within these regions (Brown and Lugo 1990a, Hughes et a.l, 1999).

Where succession begins in an environment that has already been more or less modified by a period of occupancy by living organism, it is called secondary succession. Forest clear cuts and abandoned agricultural fields both undergo secondary succession. While secondary succession has always been an integral process in tropical forest ecosystems following natural disturbances (e.g., hurricanes and tree falls due to senescence), current increases in secondary forest cover are primarily the result of anthropogenic disturbances such as logging and conversion of forests to pasture and agricultural lands (Brown and Lugo 1990a, Skole and Tucker 1993, Hughes et al., 1999).

In general, secondary forests have rapid rates of aboveground production, particularly during the initial stages of succession (Ewel 1980, Brown and Lugo 1990a, Lugo 1992, Lugo and Brown 1992, Hughes et al., 1999). However, the total benefits of these ecosystem services provided by forest fallows and the potential for forest production have not been evaluated in Northen Yucatan, largely because forest productivity under secondary land cover has rarely been measured with an eye to marketable products. Even the important production of fuel wood is often based more on market than on ecosystem observation. Sustainable management systems, rates of natural regeneration, the role of enrichment planting or improved fallows, and the forestry potential of agroforestry practices are only beginning to be explored.

Soil fertility studies in the semiarid tropics, and particularly of calcareous tropical soils, are also limited. The assessment of the nutritional conditions of soils along a forest chronosecuence may contribute to design soil and forest management strategies. Suitable and sensitive techniques, which combine the influence of climatic 
factors and biochemical processes in the soil, permit a better understanding of these semiarid ecosystems.

Basic cations such as $\mathrm{Ca}, \mathrm{Mg}$, and $\mathrm{K}$ play important roles in a variety of plant functions. Soil fertility and productivity may be limited by low availability of these cations (Campo et al. 2000). Weisbach et al. (2002) reported low levels of $\mathrm{K}$ in the Yucatecan soils limiting their productivity. In calcareous soils, exchangeable Mg and $\mathrm{K}$ are usually low, due to an imbalance between plant available $\mathrm{Ca}, \mathrm{Mg}$, and $\mathrm{K}$ ions. The proportion of $\mathrm{Ca}$ related to the others base cations may be more than $80 \%$, whereas exchangeable Mg could be found at levels less than 4\% (Hagin and Tucker, 1982 and Marschner, 1995 in Imas, 2000), and exchangeable K accounts for a variable percentage (0.5 - 50\%) (Baligar and Bennett, 1986).

Consequently, one of the primary objectives of this study was to quantify the effects of successional time (i.e., time since abandonment) on accumulations of aboveground biomass and elements in secondary forests of the Northern Yucatan Peninsula, and, to quantify the degree to which secondary forests may act as $\mathrm{C}$ and nutrient sinks in semiarid regions of Yucatan, Mexico. To do this, we quantified total aboveground biomass as well as Pools of Total C, N, S and exchangeable $\mathrm{Ca}, \mathrm{K}$ and $\mathrm{Mg}$ in mineral soils. We also quantified N, S, and $\mathrm{K}$ in leaves and litter at secondary forest sites that varied with regard to age (i.e., from 1 to $50 \mathrm{yr}$ ). We then used this secondary forest chronosequence to quantify potential rates of aboveground biomass and mineral soil pool accumulation, to document changes in partitioning of aboveground biomass and elemental pools between structural components through time, and to evaluate the influence of site age on accumulation rates.

\section{Research questions}

1) What are the accumulation rates of biomass, $C$, and soil nutrients in secondary forest and how do they compare with other forests?

2) Has secondary forest the potential to assimilate and restore the carbon and nutrients that are lost during Sisal cultivation? 
3) What are species composition, structure and abundance of young secondary forest?

\section{Hypothesis}

There is an increasing stock of carbon, biomass and nutrients in later succession stages of forest and a significant relationships soil-plant in both growth and nutrient content.

\subsection{MATERIAL AND METHODS}

\section{Study areas}

Located on the northwest section of the Yucatán Peninsula, the study site is flat with vegetation consisting of thorn scrub and cacti. Endemism is high due to the isolation of this dry forest; this region contains 10 of the 14 endemic cacti of the Yucatán peninsula (CICY, 1993). This region is also important for endemic and migratory birds from North America are found in this ecoregion. This region is threatened by cattle ranching and agriculture development, at least one endemic species of cacti Pereskipsis scandens has become extinct.

The region is situated on the northwestern portion of the Yucatán Peninsula. The forests grow on a vast portion of flat terrain $(<400 \mathrm{~m}$ above sea level), composed of limestone of coraline origin. Soils are generally young and of calcareous origin; and drainage is extensive, thus the soils hardly ever flood (CICY 1993). The climate is tropical subhumid but becomes drier in the central portion of this region. As in other subtropical forests, there is a long dry season that is responsible for the deciduous nature of the forests. Precipitation levels do not reach above $1200 \mathrm{~mm} /$ year, although the northern portions receive slightly less. Dominant vegetative species in the central portion of the region are: tsalam (Lysiloma bahamensis) and jabín (Piscidia piscipula), and can be accompanied by Alvaradoa amorphoides, Bursera simaruba, Cedrela mexicana, Chlorophora tinctoria, Cordia gerascanthus and Lonchocarpus rugosus in other areas. The accompanying species are Vitex gaumeri, Brosimum alicastrum, Caesalpinia gaumeri, Cedrela odorata, Ceiba pentandra and Sideroxylon 
fuetidissimum. In the northern part of the ecoregion, near the coast, cacti become more abundant. Common cactus species include: Cephalocereus gaumeri, Pterocereus gaumeri and Lemaireocereus griseus. Herbaceous plants, epiphytes and fungi are rather scarce, but bromeliads like Tillandsia do grow on some trees.

Rico-Gray et al. (1991) presented the uses that the Maya of Tixcacaltuyub and Tixpeual, Yucatán, México, have for the trees and shrubs of their surrounding tropical dry and deciduous forests; adding the uses for trees and shrubs in their homegardens, because they complement their basic needs. A total of 301 shrubs and tree species were counted either in the forest or homegardens sampled; 222 species (73.7\%) have at least one reported use. The species with more uses are: Bursera simaruba (10), Gliricidia sepium (10), Cordia dodecandra (9), Plumeria rubra (7), Caesalpinia gaumeri (7), Vitex gaumeri (7), Enterolobium cyclocarpum (7), and Piscidia piscipula (7). The largest number of species $(152 / 69.7 \%)$ is classified for medical purposes, followed by apiculture (87/39.9\%), food $(66 / 30.3 \%)$, fuel $(38 / 17.4 \%)$, building (41/18.8\%) and timber (25/11.5\%). Despite the lack of important commercial species (timber, fruit) in this type of tropical forest, we discuss the importance of the tropical dry forest of Yucatán as an area where management could lead to sustainable production of honey, deer and building material for houses.

The dry forests of Yucatán constitute a unique island of vegetation in the Gulf of Mexico region. They are isolated from other dry forests by the sea and by a vast extension of humid forests in the Maya region. Some researchers hypothesize that the isolation of the dry forests has been responsible for the unique composition of the region's flora and fauna, as well as for the specific processes governing animal and plant dispersion.

This study was carried out in six localities in a semiarid ecosystem of the Northern Yucatan Peninsula. The vegetation of the area has been study by Gonzalez-Iturbe et al. (2001) and Thien et al. (1982) who described the vegetation as in transition between dry subtropical forest and arid tropical forest according to Holdrige (1967). Miranda and Hernandez (1964) cited by Gonzalez-Iturbe et al. (2001) classified it as a low deciduous forest and mention another particular association of low deciduous forest with columnar cacti. 
The average annual precipitation is about $760 \mathrm{~mm}$ and the average temperature is 26 ${ }^{\circ} \mathrm{C}$. The climate in the region is seasonal; the rainy season contributes $75 \%$ of the total precipitation (Gonzalez-Iturbe et al. 2001, Durch, 1988). According to Roig et al. (2003), This seasonality can influence the physiology of plants in terms of leaf fall and reduced growth activity.

The geology is characterized by the presence of calcareous rock of Pleistocene age as well as recent sedimentary material which forms a narrow border between the Carrillo Puerto Formation and the coast line (Gonzalez-Iturbe et al. 2001, Durch, 1988).

Soils are extremely young. Gonzalez-Iturbe et al. (2001) refers to INEGI (1984), the following soil types are found: orthic and mollic solonchac, litosols and rendzinas. Litosols cover a large portion of the north, central and western areas, while rendzimas are frecuently associated with litosols and are dominant soils of the state.
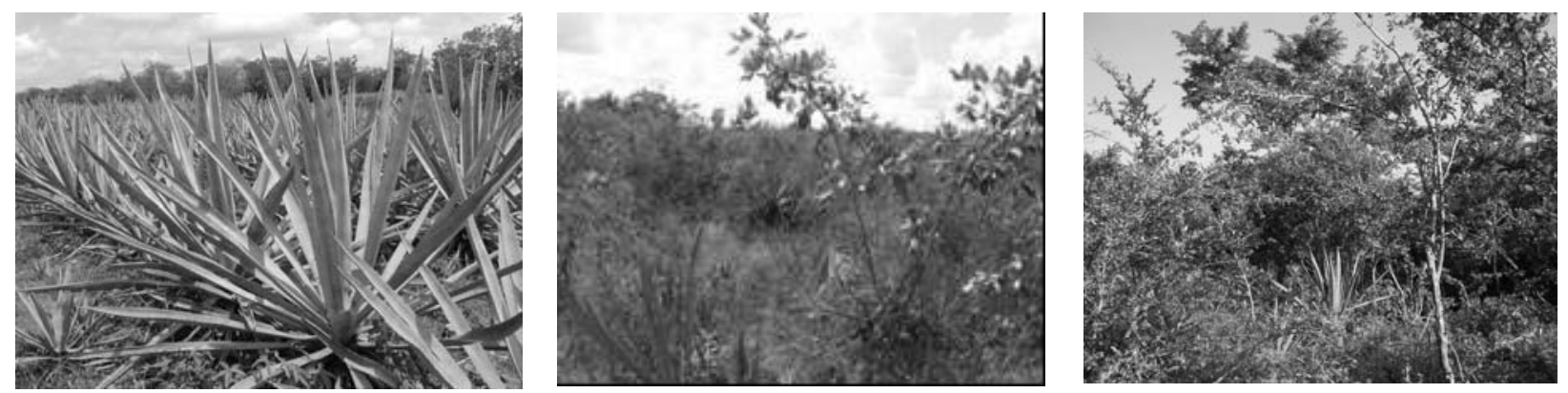

Fig 2-1. Different landuses in Semiarid Ecosystems; Sisal plantations and young secondary Forest vegetation.

\section{Site Selection and Plot Sampling Location}

We sampled 18 secondary forest sites ranging in age from 3 to $50 \mathrm{yr}$ since abandonment plus an adult Sisal site. Samples were stratified into three age classes: SS1 ( $<15 \mathrm{yr})$, SS2 (15 - $30 \mathrm{yr}), \mathrm{SS} 3(>30 \mathrm{yr})$. The land use history and time since abandonment of each site were obtained from previous studies and interviews with the local landowners who had managed selected sites. 
Stands in each sample site were selected by interpreting and visually inspecting aerial photography from the region.

Total aboveground biomass (TAGB) and pools of $\mathrm{C}, \mathrm{N}, \mathrm{S}, \mathrm{K}, \mathrm{Ca}$ and $\mathrm{Mg}$ in leaves and litter were analyzed at each of the 18 secondary forest sites.
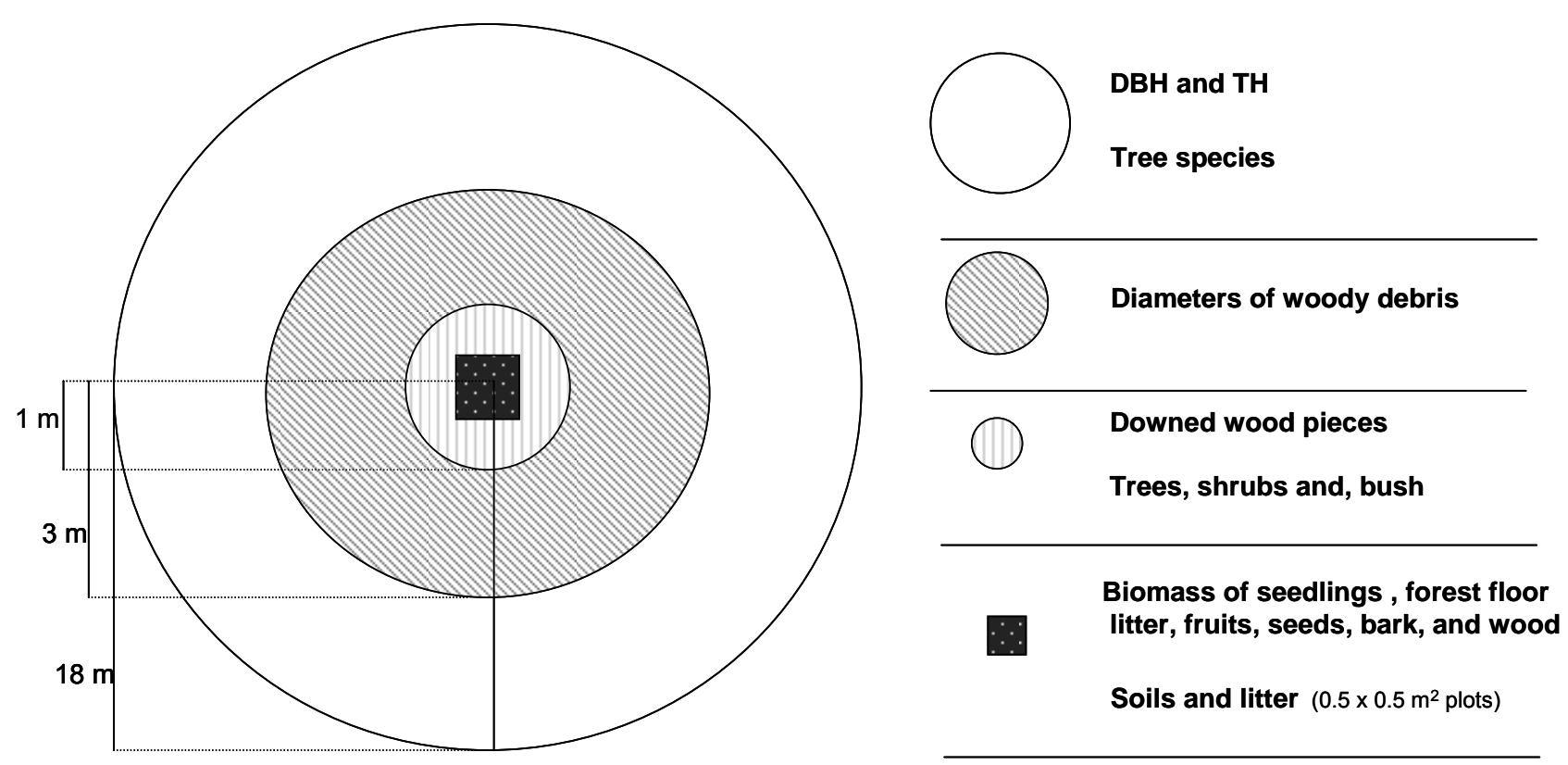

Fig 2-2. Plot design for collection of soil and vegetation samples 


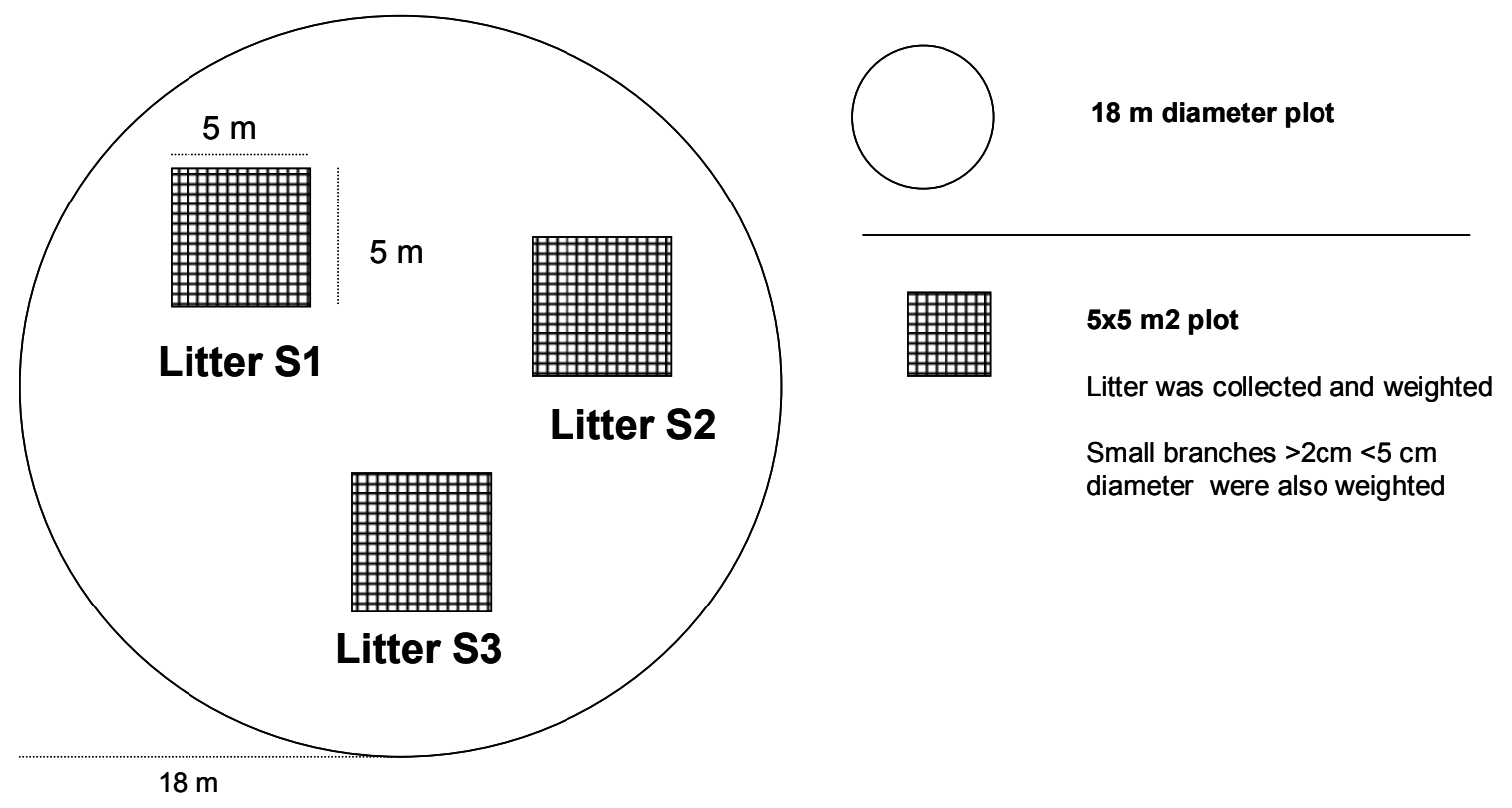

Fig 2-3. Plot design for collection of litter samples (5 plots with 3 repetitions)

Following Brown et al. (2002), TAGB as well as nutrient pools in soils of secondary forest sites were quantified using stratified random sampling. A set of circular plots of $18 \mathrm{~m}$ radius were established at each site in which the diameter at breast height (dbh, $1.3 \mathrm{~m}$ ) for all trees and dead trees $>8 \mathrm{~cm}$ dbh were measured and tree species identified. We considered a sample intensity of $0.1 \%$ which means 10 plots every 6.157 ha. Sample area and stand stratification were obtained from aerial photographs and through GPS survey. Each 18-m radius plot was placed randomly on the stand.

Woody debris was measured at a central plot of $0.25 \mathrm{~m}^{2}$ into the $18-\mathrm{m}$ radius plot (see figure 2-2). Diameters of woody debris were recorded for all large wood pieces ( $>10$ $\mathrm{cm}$ in diameter) pieces were codified into sound and rotten classes based on their degree of decomposition.

Downed wood pieces between 2 and $10 \mathrm{~cm}$ in diameter were counted along a $1-\mathrm{m}$ radius plot in the center of the $18-\mathrm{m}$ radius plot.

Following Hughes et al. (1999), the quadratic mean diameter of woody debris and specific gravity values for each particle class (i.e., $2-10 \mathrm{~cm}$ diameter, $>8 \mathrm{~cm}$ diameter sound, and $>10 \mathrm{~cm}$ diameter rotten) were determined by collecting wood debris 
samples at random within a subset of the 10 forest sites, and mean values of each parameter was used in models to calculate biomass.

Trees, shrubs, bush, palms and cactus at least $1.3 \mathrm{~m}$ in height but $<8 \mathrm{~cm}$ dbh were measured within the $1 \mathrm{~m}$ radius plot. Biomass of seedlings (i.e., vegetation $<1.3 \mathrm{~m}$ in height) and forest floor litter (i.e., fallen leaves, fruits, seeds, bark, and wood $<2 \mathrm{~cm}$ diameter) were destructively sampled in $50 \times 50 \mathrm{~cm}$ plots place at the center of each $18-\mathrm{m}$ radius plot.

The following indexes and parameters were calculated:

1) Basal area and volume will be calculated:

$$
B A=\sum_{1}^{n} \pi\left(D_{i} / 2\right)^{2}
$$

Where: BA is Basal Area $\left(\mathrm{cm}^{2}\right)$

$\mathrm{D}$ is $\mathrm{dbh}(\mathrm{cm})$

$$
V=\sum_{1}^{n} B A \times H \times F F
$$

Where: $\mathrm{V}$ is volume $\left(\mathrm{m}^{3}\right)$

$\mathrm{H}$ is total height $(\mathrm{m})$

FF is form factor $(0.65)$

2) For each age class (a) structure (frequency distribution of height and DBH of individuals of more than $1 \mathrm{~cm} \mathrm{DBH}$.

3) For all individuals of more than $1 \mathrm{~cm} \mathrm{DBH:} \mathrm{(a)} \mathrm{relative} \mathrm{density} \mathrm{by} \mathrm{species} \mathrm{(no.}$ of a species/no. of individuals of all species X 100) (b) relative frequency by species (no of plots in which a species occurred/total no. of occurrences of all species X 100); (c) relative dominance (total basal area of a species/total basal area of all species X 100 - basal area was used as an indicator of biomass); and (d) species importance value (IV) (relative density + relative frequency + relative dominance). 


\section{Soil fertility and laboratory Analyses}

Pools of $\mathrm{C}, \mathrm{N}$ and $\mathrm{S}$ in mineral soils were determined from three sample points collected randomly in each of the 3-m radius plot. Samples were collected at 2.5-10 $\mathrm{cm}$ depths. In addition, we assessed the levels of exchangeable $\mathrm{Ca}, \mathrm{Mg}$ and $\mathrm{K}$. Both measurements permitted to establish a base line of soil fertility in these calcareous tropical soils.

Following Hughes et al. (1999), all soil and vegetation samples were oven dried to a constant mass at a temperature of approximately $65{ }^{\circ} \mathrm{C}$. Vegetation samples were ground to pass through a 40 -mesh screen $(0.5 \mathrm{~mm})$ using a sample mill.

Soil samples were sieved to remove roots $>2 \mathrm{~mm}$ in diameter and ground to pass through a 60-mesh screen (250-micrometer pore size). Total $\mathrm{C}, \mathrm{N}$, and $\mathrm{S}$ concentrations in biomass and mineral soils were determined by the elemental analyzer NA 1500 (Carlo-Erba, 1990). For the characterization of other nutrients, 200 mg dry leaves were digested in $2 \mathrm{~mL}$ concentrated $\mathrm{HNO}_{3}$ at $105^{\circ} \mathrm{C}$ for four hours. $\mathrm{K}$, $\mathrm{Ca}$ and $\mathrm{Mg}$ were analyzed with an atomic absorption spectrometer.

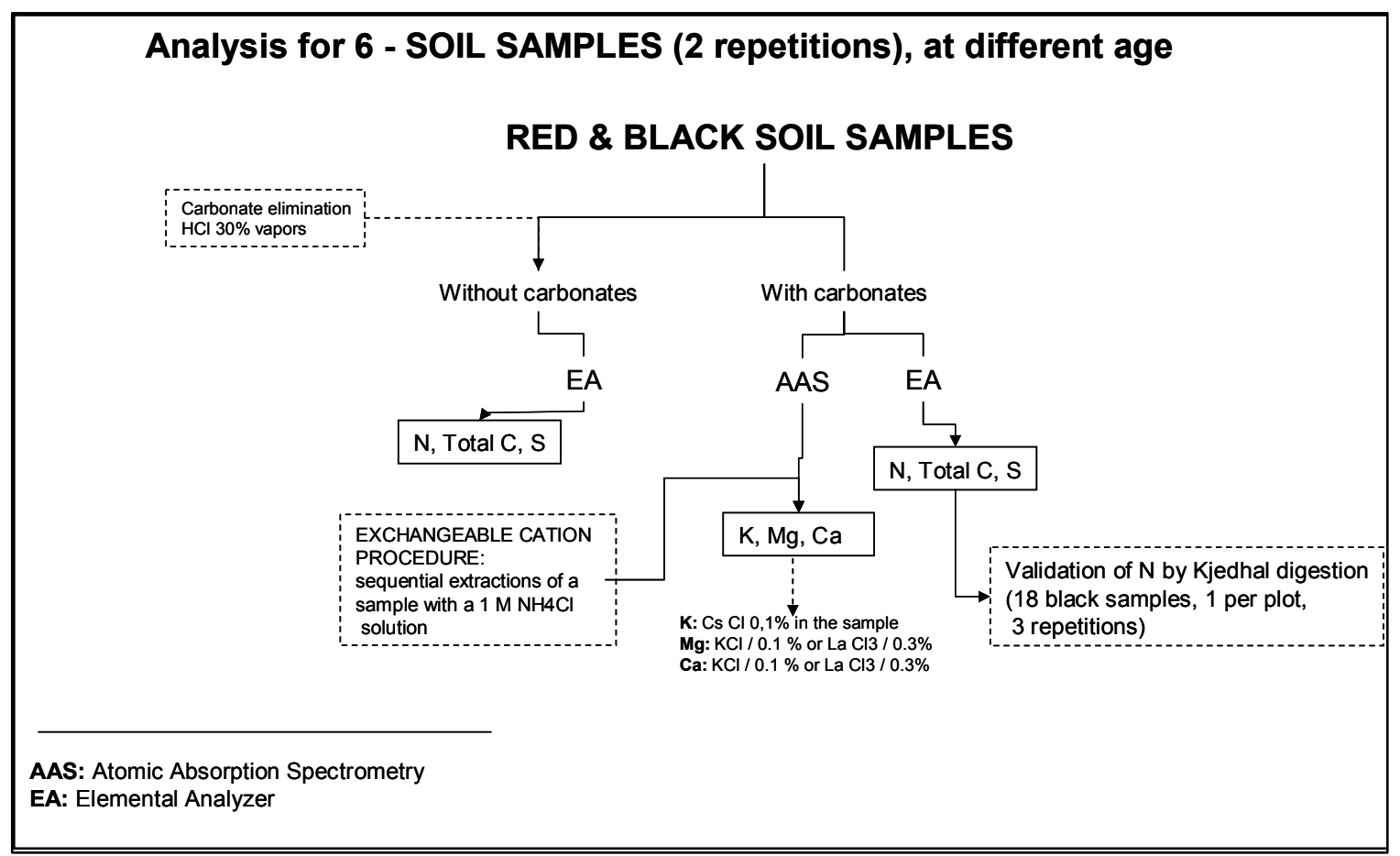

Fig 2-4. Methodology considered for soil analysis. 
The procedure for analyzing the Organic Carbon (OC) content in soil samples was divided various phases. First, an acid pre-treatment was performed to remove the Inorganic Carbon (IC).

Calcareous soils have a large proportion of IC in the soil matrix, mainly in form of CaCO3 (Shang and Tiessen 2003), in some cases reaching 95\% of the substrate (Graefe 2003). Its removal was necessary prior to OC determination using a methodology adapted from Harris et al. (2001) and Echenique (2005). The methodology is based on the usage of acid fumes coming from concentrated hydrochloric acid $(\mathrm{HCl})$ for removing IC in soil samples. Fumigating soil with concentrate $\mathrm{HCl}$ reduces or even eliminates OC losses (soluble OC).

Total (TC) and organic (OC) carbon, as well as, total nitrogen $(\mathrm{N})$ were measured by dry combustion with CHNS analyzer (Model VARIO EL III, Elementar Analysensysteme GmbH, Hanau, Germany). For TC and N, 60-mg air-dried soil, ground in the ball-mill, were placed into tin caps. The tin caps were closed hermetically and stored in dry conditions until measurement. OC content was determined after removal of carbonates by acid treatment with $\mathrm{HCl}$ following the methodology described by Echenique (2005). $\mathrm{HCl}$ is generally used to estimate carbonate content in soils. This acid reacts quantitatively with all carbonate present, except for siderite. Concentrated acid reacts quickly with calcite and aragonite, but slowly with dolomite (Bisutti et al., 2004).

OC was determined using the formula developed by Echenique (2005). TC data of the carbonate-free samples were converted into $\mathrm{OC} \mathrm{g} \mathrm{kg}^{-1}$ by the following formula:

OC $\left(\mathrm{g} \mathrm{kg}^{-1}\right)=\left[\right.$ soil free of $\mathrm{CaCO}_{3}(\mathrm{~g}) /$ whole soil $\left.(\mathrm{g})\right]$ x TC of $\mathrm{CaCO}_{3}$-free samples $(\mathrm{g}$ $\left.\mathrm{kg}^{-1}\right)$

Since all the $\mathrm{CaCO}_{3}$ (in form of gravel) needs to be broken into smaller particles capable of being removed by the acid vapours, soil samples were ground with a mortar and pestle to ca. $1 \mathrm{~mm}$. 
For the next step, $5 \mathrm{~g}$ of each soil sample was placed in a petridish and was homogeneously moistened with pure water to field capacity (approx. $1.8 \mathrm{ml}$ ) using a pipette. They were then placed in a desiccator for the acid fumigation treatment. Concentrated $\mathrm{HCl}(30 \%)$ in a proportion of $8.6 \mathrm{ml}$ acid $\mathrm{g}-1$ soil was placed in the bottom of the desiccator. By doing this, only acid vapors were allowed to react with soil particles. The desiccator was left overnight in a $40^{\circ} \mathrm{C}$ water-bath to activate the acid reaction.

Because black soils contain a greater amount of carbonates a simple test had to be performed in order to detect if the overnight treatment with fumes was enough to eliminate all of them. The verification was done by dripping $2 \mathrm{M} \mathrm{HCl}$ with a pipette on black-soil samples. The presence of remaining carbonates in the soil was corroborated by the appearance of bubbles from the releasing of $\mathrm{CO}_{2}$ after the chemical reaction. These samples were left more hours under the effect of acid vapors and tested again before proceeding with the next step. Some samples formed a superficial dry crust after overnight exposure. Since soil must be moist during the treatment (Harris et al. 2001), samples were re-moistened and placed again in the desiccators before continuing with the procedure. After the acid vapor treatment, soil samples were transferred into $100-\mathrm{ml}$ flasks and washed with $50 \mathrm{ml}$ of $2 \mathrm{MHCl}$ for removing residual carbonates in some samples. If foam thickness exceeded $2 \mathrm{~cm}$ the procedure was repeated from the beginning. The suspensions were hand shaken and caps were removed for releasing pressure and finally caped flasks were placed in the mechanic shaker and shaken for 2 hours at $150 \mathrm{rpm}$. After that, the samples were dried in the oven at $40^{\circ} \mathrm{C}$ and prepared in the same way that the samples for total carbon and nitrogen and measured in the CHNS analyzer.

The following step had as objective the removal of remaining carbonates in the samples. The concentration of the acid used was considered sufficiently weak to avoid solubilization of $\mathrm{OM}$ but strong enough to allow reaction with residual $\mathrm{CaCO}_{3}$. When acid was added some black samples still foamed. Samples were placed in a mechanical shaker for 2 hours at 150 cycle min-1.

Exchangeable $\mathrm{Ca}, \mathrm{Mg}$ and $\mathrm{K}$ were determined by an extraction with $1 \mathrm{M} \mathrm{NH}_{4} \mathrm{Cl}$ and a correction with a separate water extraction. The $2 \mathrm{~g}$-soil samples were mixed with 20 
$\mathrm{ml} 1 \mathrm{M} \mathrm{NH} \mathrm{N}_{4} \mathrm{Cl}$ and shaken in an oscillatory shaker during one hour. Then, the samples were centrifuged during 4 minutes at $3000 \mathrm{rpm}$ and decanted into 100-ml flasks. This procedure was repeated 3 times and finally more $1 \mathrm{M} \mathrm{NH} \mathrm{NH}_{4}$ was added to make volume. The extracts were kept at $4{ }^{\circ} \mathrm{C}$ until the analyses. The same procedure was repeated for the extraction with deionized water instead of $1 \mathrm{M} \mathrm{NH}{ }_{4} \mathrm{Cl}$. Afterward, the results from the water extraction were subtracted from the $1 \mathrm{M} \mathrm{NH}_{4} \mathrm{Cl}$ extractable cations to obtain the exchangeable ones. $\mathrm{Ca}^{2+}$ and $\mathrm{Mg}^{2+}$ were determined by atomic absorption and $\mathrm{K}^{+}$by flame emission spectroscopy in the NOVAA 315 stand alone Flame AAS (Analytic, Jena AG, Germany).

For all cations, the readily exchangeable value was determined using the next formula:

$$
\begin{array}{r}
\text { Exc.Cation }\left(\mathrm{mmol} \mathrm{kg}^{-1}\right)= \\
\mathrm{NH}_{4} \mathrm{Cl} \text { extractable cation }\left(\mathrm{mmol} \mathrm{kg}{ }^{-1}\right) \\
\mathrm{H}_{2} \mathrm{O} \text { extractable cation }\left(\mathrm{mmol} \mathrm{kg}^{-1}\right) .
\end{array}
$$

Soils were analyzed independently considering the differences in soil management and land uses between both countries. For the analyses, data was arranged by soil type and land uses.

\section{Statistical Analyses}

For data analyses the software used was STATISTICA 6.0 (Stat Soft Inc., 2001). Data were tested by two-way ANOVA with the factors land use and soil type, for determining the possible interaction between both factors. Subsequently, whenever the two-way ANOVA indicated significant interactions for $p<0.05$, the results were analyzed by one-way ANOVA for red and black soils independently. If the interactions were not significant, the analyses were done for the significant factor (land use and/ or soil type) without distinctions regarding soil type or land uses. Comparisons were performed using Fisher protected LSD test (FPLSD). 


\section{Forest Measurements}

Biomass of trees $>8 \mathrm{~cm}$ dbh were calculated using an allometric model proposed by Brown et al. (1989) for tropical dry deciduous forest. This model uses tree dbh, height, and wood density to predict biomass.

Table 2-1. Regression equations for estimating biomass of tropical trees. $\mathrm{Y}=$ biomass per tree in $\mathrm{kg}, \mathrm{D}=\mathrm{dbh}$ in $\mathrm{cm}$, and $\mathrm{BA}=$ basal area in $\mathrm{cm}^{2}$.

\begin{tabular}{|c|c|c|c|c|c|}
\hline $\begin{array}{l}\text { Equation } \\
\text { Number }\end{array}$ & Author & Equation & Range in dbh (cm) & Number of trees & Adjusted r2 \\
\hline 1 & Brown et al. (1989) & $\mathrm{Y}=\exp \{-1.996+2.32 * \ln (\mathrm{D})\}$ & $4-50$ & 28 & 0.89 \\
\hline 2 & Cairn et al. (2003) & $V=\exp \left\{-2.173+0.868 \ln \left(D^{2} H\right)+\frac{0.0939}{2}\right.$ & $1-40$ & 195 & 0,90 \\
\hline
\end{tabular}

Eq. 1 revised from Martinez-Yrizar et al. (1992) for dry forest in India for dry zones with rainfall less than $900 \mathrm{~mm}$.

Eq. 2 revised from Cairns et al. (2003) for central Quintana Roo state, in the medium stature semi-evergreen forest (Miranda and Hernandez, 1964) receiving approximately $1200 \mathrm{~mm}$ mean annual rainfall.

Tree heights were determined by using a regression model which was developed from a sample of trees of varying species sampled for this study and from available data. Species-specific wood density values were is taken from literature. In cases where density values are not available, mean values derived from congeners were used.

A general logistic growth equation, the Richards function as described by Ruiz et al. (2003), Hughes et al. (1999) and Cooper (1983), was proposed to predict mean annual aboveground biomass accumulation (ABA) based on the age and TAGB of the secondary forests sampled in selected sites. The form of this model is:

$$
\mathrm{TAGB}_{\mathrm{t}}=\mathrm{TAGB}_{\max } *\left(1-\exp ^{\left.(-\mathrm{b} 1 \mathrm{xt})^{* * \mathrm{~b} 2}\right]}\right.
$$

Where:

$\mathrm{TAGB}_{\mathrm{t}}=\mathrm{TAGB}$ at a given time following site abandonment; 
$\mathrm{TAGB}_{\max }=$ the potential maximum of TAGB obtained from the average TAGB of primary forest sampled in Dzibilchaltun;

$\mathrm{t}=$ the period of secondary succession or the age of a given secondary forest;

b1 and b2 are parameters controlling the rate of mean annual ABA and the inflection point of the accumulation curve, respectively.

In addition, we assumed that secondary forests are equivalent to primary forests regarding TAGB, when they reached $90 \%$, of the $\mathrm{TAGB}_{\max }$ value.

For standing dead trees $>8 \mathrm{~cm} \mathrm{dbh}$, height as well as dbh were measured in the $18-\mathrm{m}$ radius plot, and their volumes calculated as cylinders. A mean wood density value in terms of $\mathrm{g} / \mathrm{cm}^{3}$ was derived from samples of sound wood debris which was used to convert volume of standing dead trees to biomass.

Biomass of trees $>1.3 \mathrm{~m}$ in height but $<8 \mathrm{~cm}$ dbh was calculated using a regression equation developed from measures of a set of trees (approximately 50 units) which has been harvested in three of the six study sites. Biomass of dead trees $>1.3 \mathrm{~m}$ in height but $<8 \mathrm{~cm}$ dbh was calculated using a regression model of dbh vs. main stem biomass of the set of 50 trees.

We calculated species diversity using the Shannon-Wiener index, Importance Index Value (IVI) and Evenness Index which varies from 0 (completely uneven distribution of individuals by species) to 1 (all species have equal number of individuals) (Pielou 1966). The Shannon's Diversity Index, and Evenness Index (Shannon and Weaver, 1949) takes into account subspecies richness and proportion of each subspecies within a zone. The first step is to calculate Pi for each category subspecies. You then multiply this number by the log of the number. While you may use any base, the natural $\log$ is commonly used. The index is computed from the negative sum of these numbers. In other words, the Shannon-Wiener index is defined as:

$$
\mathrm{H}=-\operatorname{sum}(\mathrm{Pilog}[\mathrm{Pi}])
$$

Using species richness $(\mathrm{S})$ and the Shannon-Wiener index $(\mathrm{H})$, you can also compute a measure of evenness: 


$$
\mathrm{E}=\mathrm{H} / \log (\mathrm{S})
$$

Evenness (E) is a measure of how similar the abundances of different species are. When there are similar proportions of all subspecies then evenness is one, but when the abundances are very dissimilar (some rare and some common species) then the value increases. The importance value index (IVI), which is the sum of relative abundance, frequency and dominance (Lamprecht 1989), was calculated in order to determine the relevance of timber species.

A correspondence analysis was performed, and the relationship between relative abundance of the species and stand age.

\section{Nutrient pools in leaf and litter}

Nutrient pools in litter were calculated by multiplying the mass of each component by its corresponding nutrient concentration. Concentrations of $\mathrm{C}, \mathrm{N}, \mathrm{S}, \mathrm{K}, \mathrm{Mg}$, and $\mathrm{Ca}$ in trees $>8 \mathrm{~cm}$ dbh were determined in laboratory from samples of wood and sun leaves collected from randomly selected individuals at each site.

Analysis for 6 - LEAF AND LITTER SAMPLES (2 repetitions), at different age

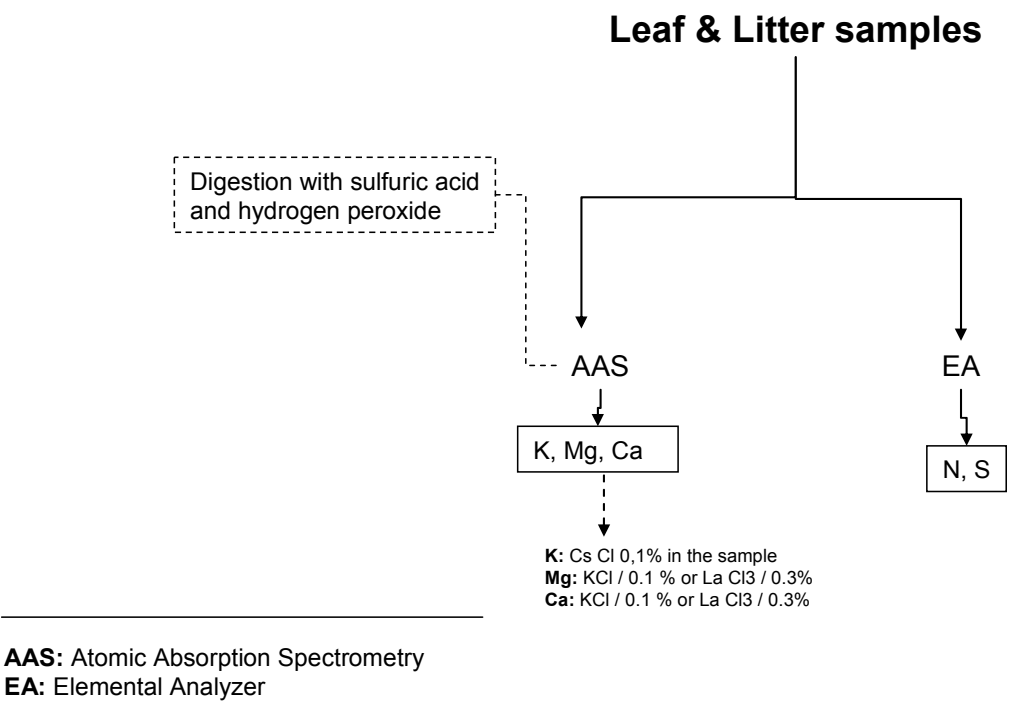

Fig 2-5. Methodology considered for leaves and litter analysis 
Wood samples were collected from trees using increment borers inserted to the center of each trunk to ensure that the entire bole is represented by each sample. Samples were taken from ten trees, collected at each site.

Five leaf samples, each consisting of subsamples taken from five trees, were collected at each site by climbing into the tree canopy. In cases in which samples are not collected from a given site, mean values derived from pooling values from all sampled sites were used. To partition leaf and wood pools, leaf biomass of each tree $>$ $8 \mathrm{~cm}$ dbh were determined using a regression equation from literature. Wood biomass of each tree was calculated by subtracting leaf biomass from the total tree biomass.

Carbon and nutrient concentrations in leaf and wood tissue of trees $<8 \mathrm{~cm}$ dbh were determined on samples collected at each secondary forest sites. Leaf and wood samples were obtained from 25 individuals selected at random at each site.

Samples were analyzed to provide five leaf and five wood samples per site. Mean values of all sites were used for trees at sites that were not directly sampled. Leaf and wood biomass of trees $<8 \mathrm{~cm}$ dbh were calculated from regression models developed from a sample of 50 trees $<8 \mathrm{~cm}$ dbh collected within the study area.

Elemental concentrations of woody debris were determined from five samples for each woody debris class. Elemental concentrations of surface layer pools (i.e., litter and seedling pools) were determined from five samples for each site.

Mass of $\mathrm{C}$ and nutrients in mineral soils were calculated by multiplying the mean elemental concentrations at each depth by the corresponding mean soil bulk density value determined for each depth at each site.

Regression analysis was used to evaluate the significance of the relationships between variables such as TAGB; C, N, S, Ca, Mg and K pools and forest age. 


\subsection{RESULTS AND DISCUSSION}

\section{Dynamics of aboveground biomass during secondary succession}

As an area proceeds from early to late stages of a succession, there is a marked change in several characteristics of the community. The life form and longevity of the dominant plants, the structure of the community, its productivity, and the ratio of green to woody biomass all undergo change.

Succession occurs as the result of either autogenic or biogenic processes (associated with the living community) or allogenic processes (associated with the physical environment), or some combination thereof. These processes can be grouped into three major mechanisms: colonization, alteration of the physical characteristics of the site and displacement of species by competition or antibiosis (Pickett et al. 1987).

Colonization is a process with two components: invasions and survival. The rate at which a site is colonized depends on both the rate (number per unit time) at which individual organism (seeds, spores, immature, or mature individuals) arrive at the site, and on their success at becoming established and surviving (Pickett et al. 1987). Success in colonization depends to a great extent on there being a site available for colonization were abandon land has a lack of competing species, or has reduced levels of competition and other negative biotic interactions to a level at which the invading species can become established. For a given rate of invasion, colonization of a moist, fertile site is likely to be much more rapid than that of a dry, infertile site because of poor survival on the latter. A fertile field is rapidly invaded by a large variety of weeds, whereas a neighbouring construction site from which the soil has been compacted or removed to expos a coarse, infertile parent material may remain virtually free of vegetation for many months or even years, in spite of receiving the same input of seeds as the fertile field (Bauhus, J., 2003)

Variation in rates of invasion and growth plays an important role in determining patterns of succession. Early seral successions are those that produce abundant seed which is successfully distributed to new sites. Such species generally grow very 
rapidly and fully occupy such sites, excluding other species with lower invasion and growth rates (eg. Gimnopodium floribundum, Guettarda elliptica, etc.) (Table 2-3).

Survival of a species that has invaded a site is a measure of its adaptation to and tolerance of the physical and biotic conditions of the site. However, by occupying the site, a species inevitably changes the site conditions, and the changes are frequently not favorable to the continued occupancy of the site by that species. The changes may either reduce the competitive abilities of the resident species or increase those of the invading species, or both. For example, shade-intolerant pioneer species create so much shade as their community develops that their own seedlings either cannot survive or they grow poorly, while shade-tolerant seedlings of invading species flourish. Failing to reproduce themselves, the pioneer species are replaced by the subsequent seral community (Bauhus, J., 2003).

The aerial cover of vegetation it is expected to modify the microclimate at the soil surface, and the area is invaded by species that are not found in the pioneer stage. After a period of the shrub stage, tree seeds that have been reaching the site all along will germinate, and seedlings of species that are tolerant of the conditions of the site will survive.

Canopy height and basal area increased with stand age, indicating that secondary forests in the study area rapidly attain a forest structure similar in many respects to mature forests. Volume and Basal Areas were significantly correlated with secondary forest age. Volume ranged from $32.0 \mathrm{~m}^{3} /$ ha in the young secondary forest to 74.9 $\mathrm{m}^{3} /$ ha (Figure 2-6) whereas Total Basal Area in ranged from $10.8 \mathrm{~m}^{2} /$ ha in the young secondary forest to $19.7 \mathrm{~m}^{2} /$ ha. Volume in the study sites increased with age (ANOVA, $\mathrm{p}<0.005$ : Figure 2-6).

Although forest biomass increased consistently with age, the number of stems in our study sites reduces as the age increases although this value was quite variable within a given age class. In the youngest age class, density ranged from 7000 to 38000 trees/ha, while mature sites had an average of 11600 trees/ha. 
We found a total of 39 species among the individual trees with $\mathrm{dbh}>8 \mathrm{~cm}, 59$ species among the individual trees with $\mathrm{dbh}<8 \mathrm{~cm}$ (Table 1), and a total of 72 different species of trees and lianas in the $1018 \mathrm{~m}^{2}$ plot.

The basal area of the SS3 forest was $19.7 \mathrm{~m}^{2} /$ ha, while the basal area of the SS2 and SS1 was $17.3 \mathrm{~m}^{2} /$ ha and $10.8 \mathrm{~m}^{2} /$ ha respectively (Fig 2-6). In the larger tree category, diameter averaged from $8.3 \mathrm{~cm}$ to $17.0 \mathrm{~cm}$ and height average ranged from 4.3 to 8.8 $\mathrm{m}$. The range in height was $1.5-3.9 \mathrm{~m}$ in the smaller tree category.

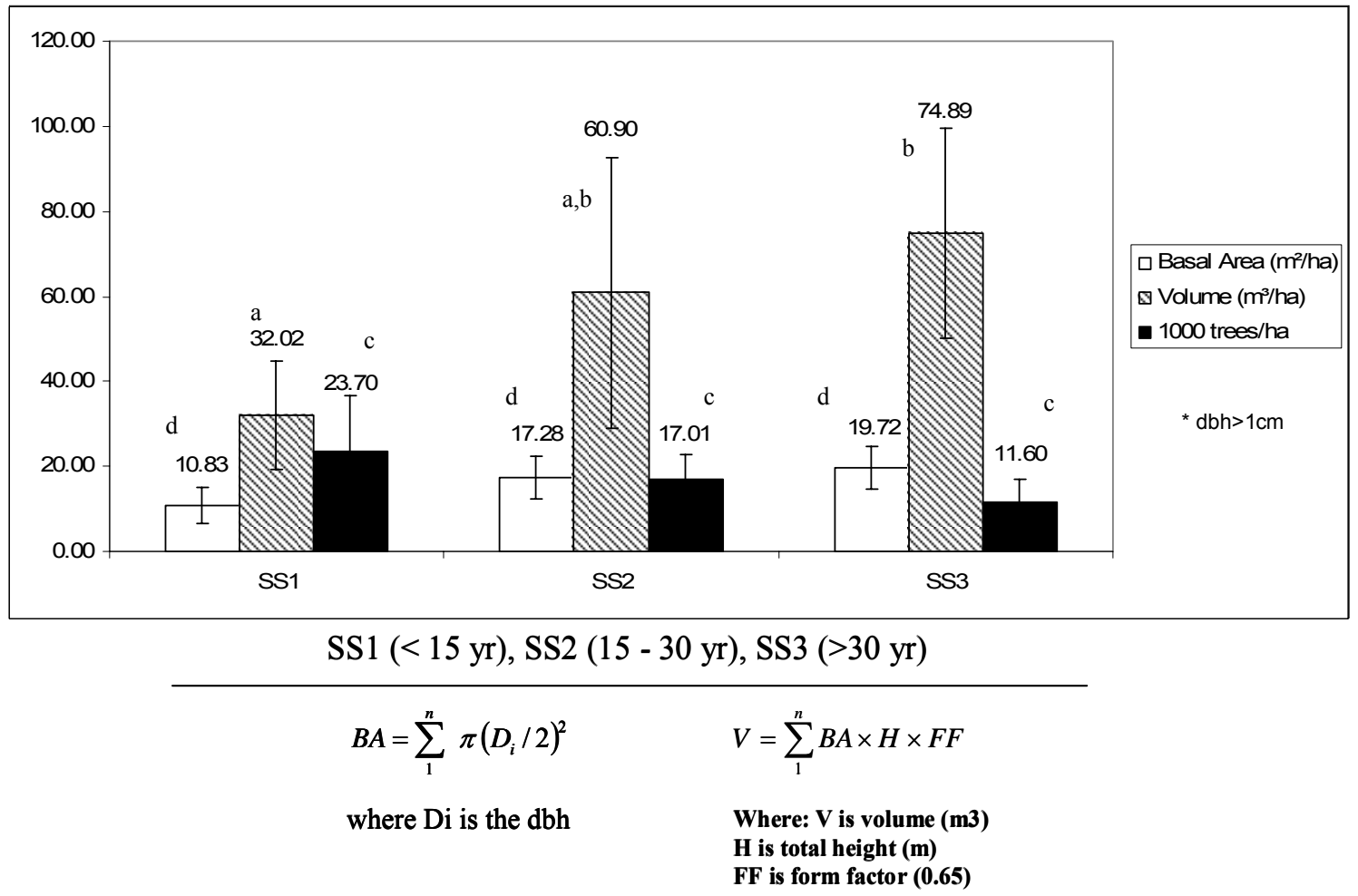

Fig 2-6. Basal area, Volume and Density of young, intermediate and mature dry secondary forest in Northern Yucatan. Numbers followed by the same letter are not significantly different by FPLSD $<0.10$ at $\mathrm{p}<0.05$.

Of all forests examined, SS1 was the one with most diverse formation with the lowest levels of evenness (Table 2-2).

A total of 63 woody species were recorded of which ca 50 percent made up 83 percent of the sampled individuals. Species diversity decreased with stand age (Peña-Claros, 2003). Therefore species showed different patterns of abundance in relation to stand age (Table 2-2). In general, the sites of advanced succession have largest number of woody species. 
The average number of individuals was larger in the SS3 plots than in the SS2 and SS1 plots. There were no significant differences between sites in the same succession stage, nor were there significant differences between average number of stems between sites in the same succession stage or between stages.

The individuals with the largest basal area belong to species such as Gimnopodium floribundium, Bursera simarouba and Lysiloma latisiliquum.

Table 2-2. Density and species richness in young, intermediate and mature dry secondary forest in Northern Yucatan. Numbers followed by the same letter are not significantly different by FPLSD $<0.10$ at $\mathrm{p}<0.05$.

\begin{tabular}{cccc} 
Indicator & \multicolumn{3}{c}{ Succecional Stages* $^{*}$} \\
\cline { 2 - 4 } Shannon Index & $2.41(\mathrm{a})$ & $2.55(\mathrm{a})$ & $2.9(\mathrm{~b})$ \\
Evenness & $0.61(\mathrm{a})$ & $0.65(\mathrm{a})$ & $0.73(\mathrm{~b})$ \\
No. of woody species & 31 & 38 & 63 \\
\hline
\end{tabular}

*SS1 (<15 yr), SS2 (15 - $30 \mathrm{yr}), \mathrm{SS} 3$ ( $>30 \mathrm{yr})$

** only stems $\mathrm{dbh}>8 \mathrm{~cm}$

The Shannon index didn't show significant differences in SS1 and SS2 plots. The SS3 plots show significant differences with SS1 and SS2. Evenness tended to be lowest in SS1 plots, intermediate in SS2 and highest in SS3 plots (Table 2-3).

The Shannon Indices for mature SS3 plots are not high, but similar to those of other sites in Yucatan state described by Gonzalez-Iturbe et al. (2002). However, in the SS2 plots, the values were low in comparison to those found by Rico-Gary (1992). The high evenness values confirm the maturity of the SS3 plots were higher than those calculated for mature semi-evergreen forest in Quintana Roo and reported by Gonzalez-Iturbe et al. (2002).

Gonzalez-Iturbe et al. (2002) found in five localities in Northern Yucatan that six families (Leguminosae with 40 species, Euphorbiaceae with 2, Compositae with 16, Graminae with 14, and Malvaceae with 12) contribute almost 50\% of the species, while 38 families ( $80 \%$ of the total) are represented by 5 species of fewer considering 
all sites together. The legumes are the most abundant in all of the succession stages: in SS2 they make up 50\% of the species, in SS1 $17 \%$ and SS3 28\%. In SS1 the Compositae, Graminae and Euphorbiaceae make up a third of the species, while in SS2 and in SS3 the Euphorbiaceae, Rubiaceae, Malpighiaceae and Cactaceae follow the legumes in importance.

Table 2-3. The importance value index (IVI) of timber species in young, intermediate and mature dry secondary forest in Northern Yucatan.

\begin{tabular}{|c|c|c|c|c|c|}
\hline \multirow{2}{*}{ Especies } & \multirow{2}{*}{ local and commercial uses } & \multicolumn{4}{|c|}{ IVI } \\
\hline & & ss1 & ss2 & ss3 & Average \\
\hline Gymnopodium floribundum & lchc & $0.0 \%$ & $6.1 \%$ & $14.3 \%$ & $6.8 \%$ \\
\hline Bursera simarouba & $m f h p h c$ & $1.5 \%$ & $8.0 \%$ & $13.6 \%$ & $7.7 \%$ \\
\hline Lysiloma latisiliquum & $m c / h t / h c$ & $4.0 \%$ & $4.3 \%$ & $13.2 \%$ & $7.2 \%$ \\
\hline Havardia albicans & Ic & $12.5 \%$ & $2.1 \%$ & $3.6 \%$ & $6.1 \%$ \\
\hline Karwinskia calderoni & fe $m$ & $6.4 \%$ & $5.2 \%$ & $3.2 \%$ & $4.9 \%$ \\
\hline Piscidia piscipula & $f c / h$ fe $r$ & $5.2 \%$ & $3.9 \%$ & $4.2 \%$ & $4.4 \%$ \\
\hline Pithecellobium leucospermum & $m$ & $0.0 \%$ & $0.0 \%$ & $4.2 \%$ & $1.4 \%$ \\
\hline Parmentiera millspaughiana & IC & $0.0 \%$ & $0.5 \%$ & $7.9 \%$ & $2.8 \%$ \\
\hline Caesalpinia gaumeri & IC & $0.4 \%$ & $0.7 \%$ & $8.5 \%$ & $3.2 \%$ \\
\hline Acacia gaumeri & $f c / h$ & $0.6 \%$ & $0.5 \%$ & $2.2 \%$ & $1.1 \%$ \\
\hline Diospyros campechiana & $m c / f d$ & $0.0 \%$ & $0.7 \%$ & $2.4 \%$ & $1.0 \%$ \\
\hline Others & & $69 \%$ & $68 \%$ & $23 \%$ & $53 \%$ \\
\hline Total & & $100 \%$ & $100 \%$ & $100 \%$ & $100 \%$ \\
\hline \multicolumn{6}{|c|}{$\begin{array}{l}\text { Only stems dbh> } 8 \mathrm{~cm} \\
\text { SS1 (< } 15 \mathrm{yr}), \mathrm{SS} 2(15-30 \mathrm{yr}), \mathrm{SS} 3 \text { (>30 yr) }\end{array}$} \\
\hline \multicolumn{6}{|l|}{ USES } \\
\hline $\begin{array}{l}m=\text { medicinal } \\
f=\text { forage } \\
c=\text { construction } \\
l=\text { fuelwood } \\
h=\text { honey producing } \\
t=\text { dyes }\end{array}$ & $\begin{array}{l}\mathrm{fe}=\text { soil fertility } \\
\mathrm{fd}=\text { food } \\
\mathrm{i}=\text { instruments } \\
\mathrm{p}=\text { live fencing } \\
\mathrm{hc}=\text { handiecrafts } \\
\mathrm{r}=\text { magical, religious. }\end{array}$ & & & & \\
\hline
\end{tabular}

The legume family is the best represented in all succession stages. This follow the same pattern found in other dry forest in Mexico (Gonzalez-Iturbe et al., 2002, RicoGray et al., 1988, Miranda, 1958).

Some trees known as a pioneer species may be also found in the late successional stage (SS3) such as Gimnopodium floribundium, Bursera simarouba and Lysiloma latisiliquum. Karwinskia calderoni and Havardia albicans are dominant in SS1, but occurs also in SS2 and SS3. Acacia Gaumeri is common in SS3 plots. 
Table 2-4. Stand density and density of most frequent species identified in young, intermediate and mature dry secondary forest in Northern Yucatan.

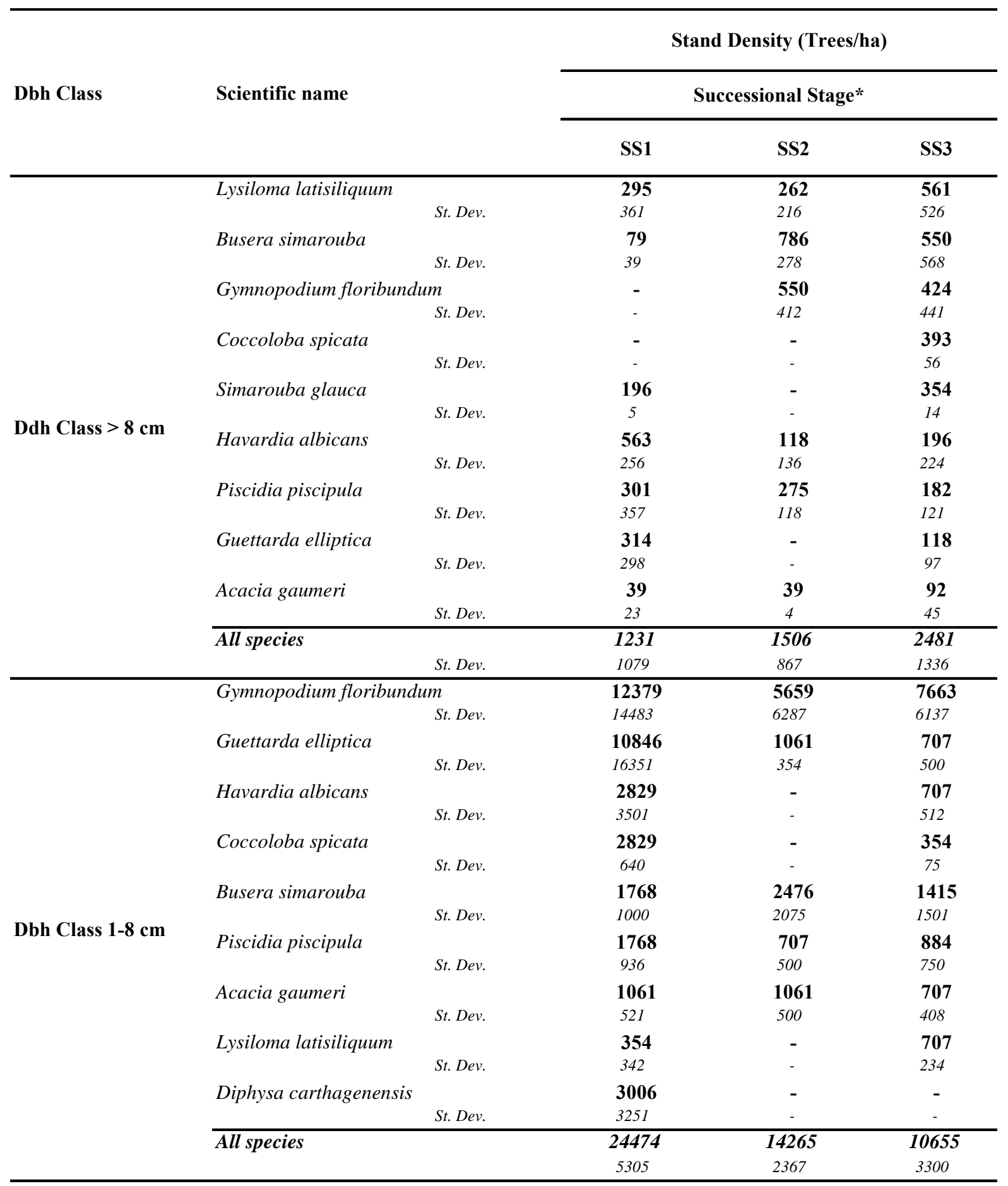

* SS1 (<10 yr), SS2 (10 - $20 \mathrm{yr})$, SS3 (>20 yr)

The management of Sisal plantations favored species with coppicing capacity (Gonzalez-Iturbe et al., 2002, Rico-Gray et al., 1988). After abandonment of the Sisal plantation, by fire took place to establish extensive cattle ranches. Invasion of 
herbaceous species by seed (Gramineae, Euphorbiaceae, Malvaceae) took place; the stumps, which were pruned during active phase of Sisal cultivation, reSprouting without being cut. Species of rapid growth, mostly legumes, get established: Lysiloma latisiliquum, Senna Racemosa, Leucaena leucocephala and Mimosa bahamensis (Gonzalez-Iturbe et al., 2002, Levy-Tacher et al., 1995). About 70\% of the species in SS2 plots sprouted. Species like Bursera simaruba and Gymnopodium floribundium, a small tree, is very aggressive due to its resprouting capacity from roots and dominates the vegetation quickly. As other trees growth taller, shade increases and the population of Gymnopodium floribundium begin thin out and eventually stop being dominant in the mature forest in SS3.

Previous studies (Mizrahi et al.,1996, Murphy and Lugo, 1986, Rico-Gray and Garcia-Franco, 1992) indicate that species with the capacity to regenerate from coppiced shoots dominate dry tropical forest.

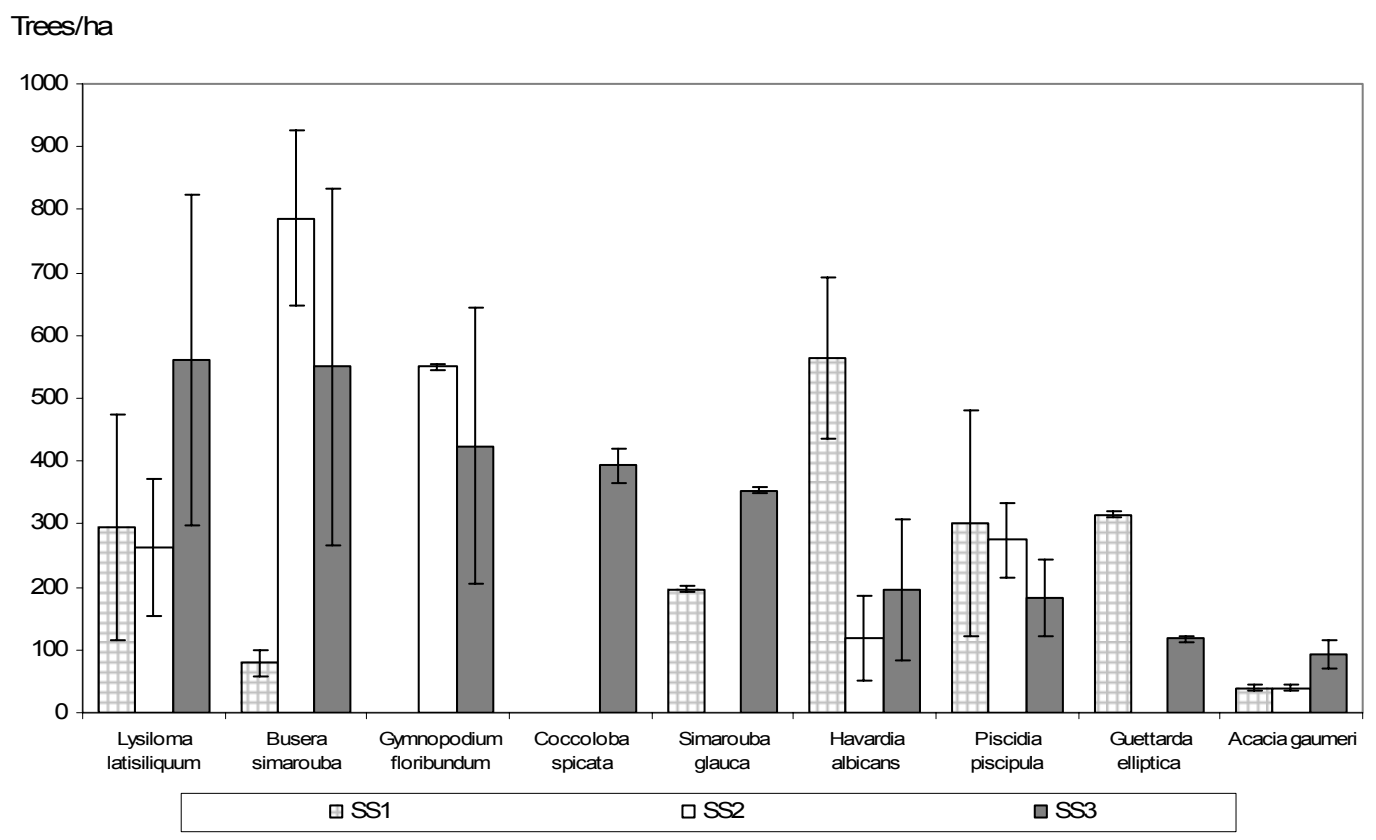

Fig 2-7. Species abundance in young, intermediate and mature dry secondary forest in Northern Yucatan. Only trees with Dbh $>8 \mathrm{~cm}$. 


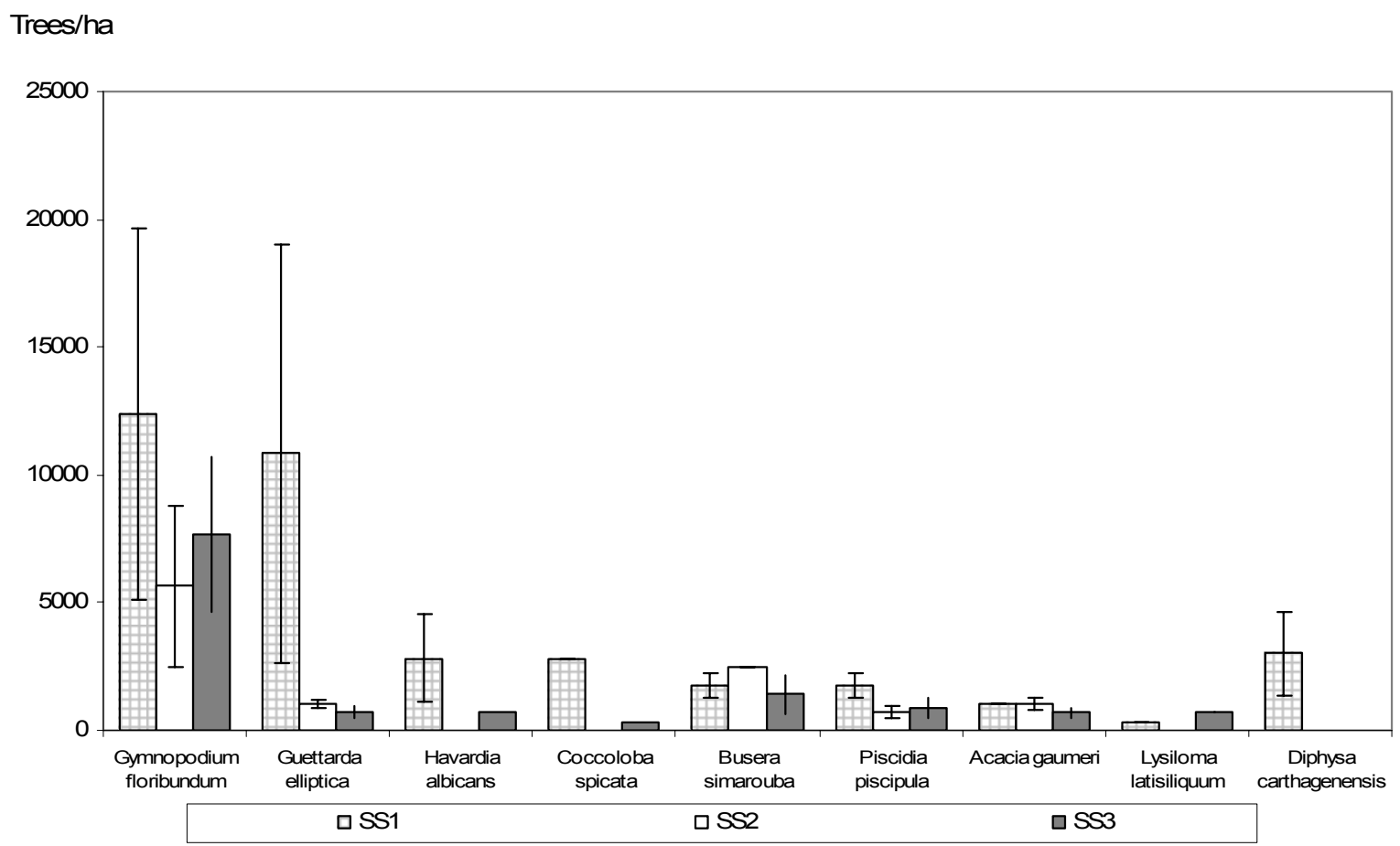

Fig 2-8. Species abundance. in young, intermediate and mature dry secondary forest in Northern Yucatan. Only trees with Dbh $<8 \mathrm{~cm}$.

Non-permanent cultivation such as slash and burn agriculture may facilitate the establishment of a larger number of species than cultivation of permanent crops such as coffee (Brown and Lugo, 1990). The permanent Sisal cultivation may have had the effect to produce such low diversity values (Gonzalez-Iturbe et al., 2002).

Forest recovery in early and intermediate succession stages after abandonment Sisal cultivation differs from late succession stages in composition, species richness, diversity and structural parameters 


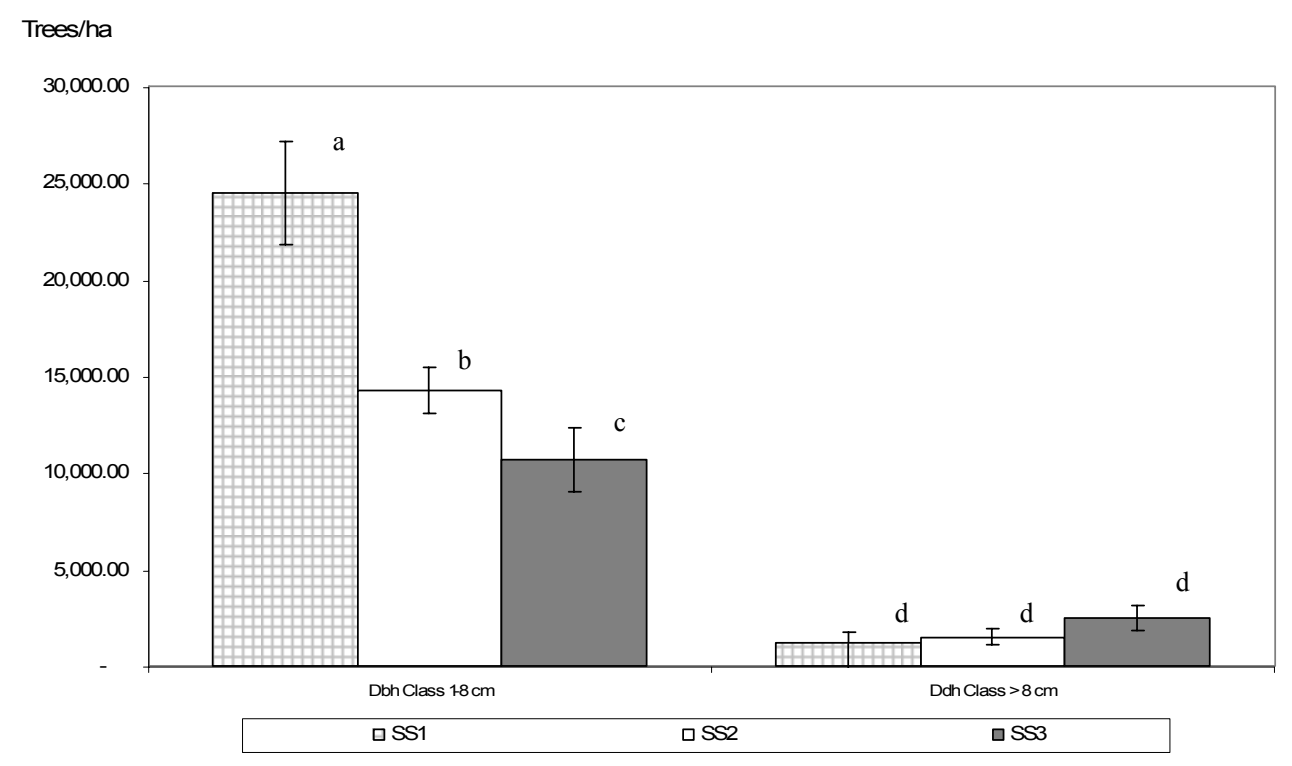

Fig 2-9. Frequency of young, intermediate and mature dry secondary forest in Northern Yucatan independently of the dbh Class. Numbers of trees followed by the same letter are No significantly different by FPLSD $<0.10$ at $\mathrm{p}<0.05$.

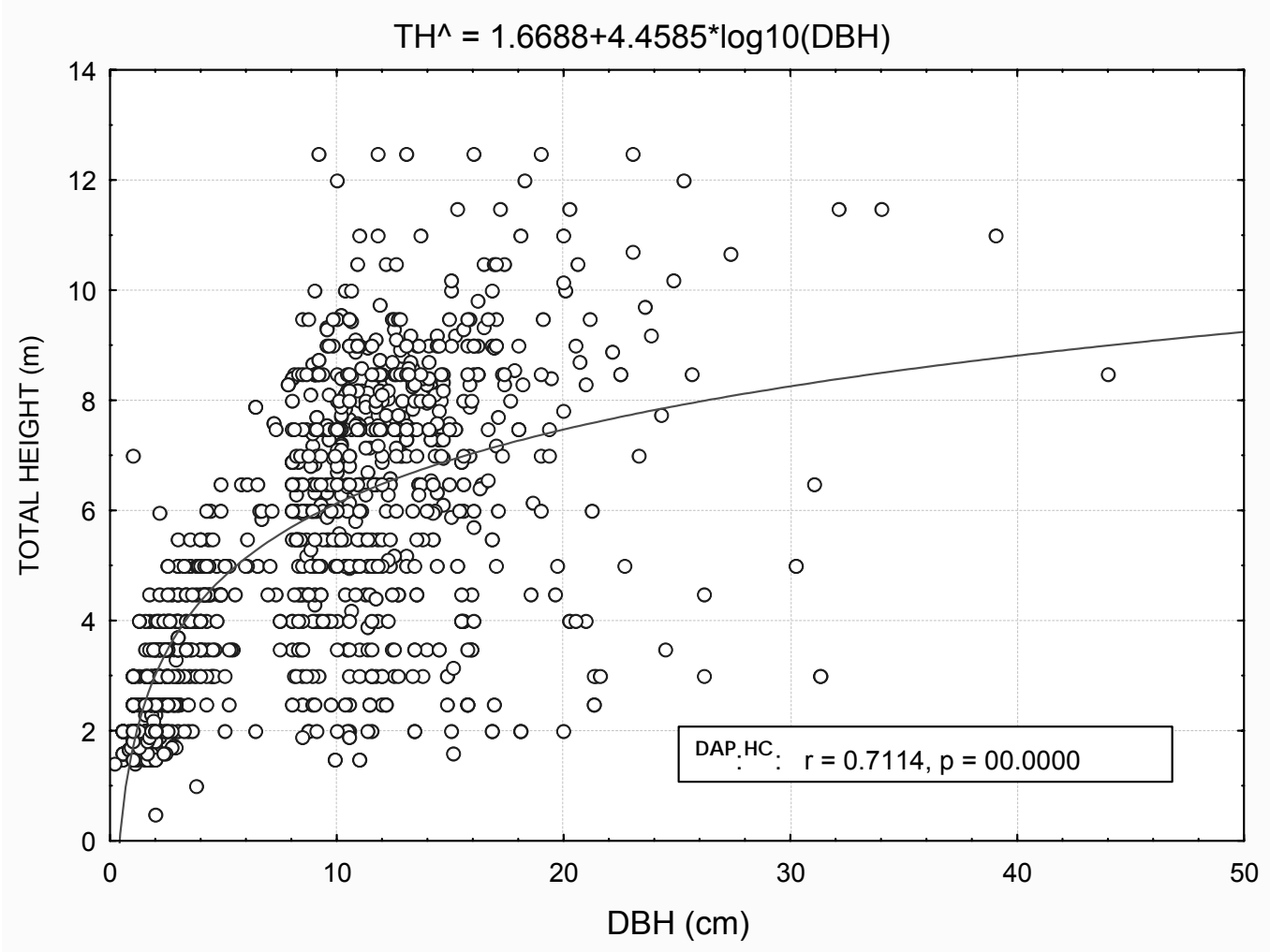

Fig 2-10. Total Height (m) predictions to the dbh. 
The average height in SS3 plots $(6,6 \mathrm{~m})$ was not significant different from that in SS2 and SS1 ( $<<0.05)$. Bursera simaruba, Lochocarpus xuul, Thouinia paucidentata, Piscidia piscipula and Lysiloma latisiliquum occurred as emergent ( $>9 \mathrm{~m})$ in most of the SS3 similar to what was fund by Gonzalez-Iturbe et al. (2002).

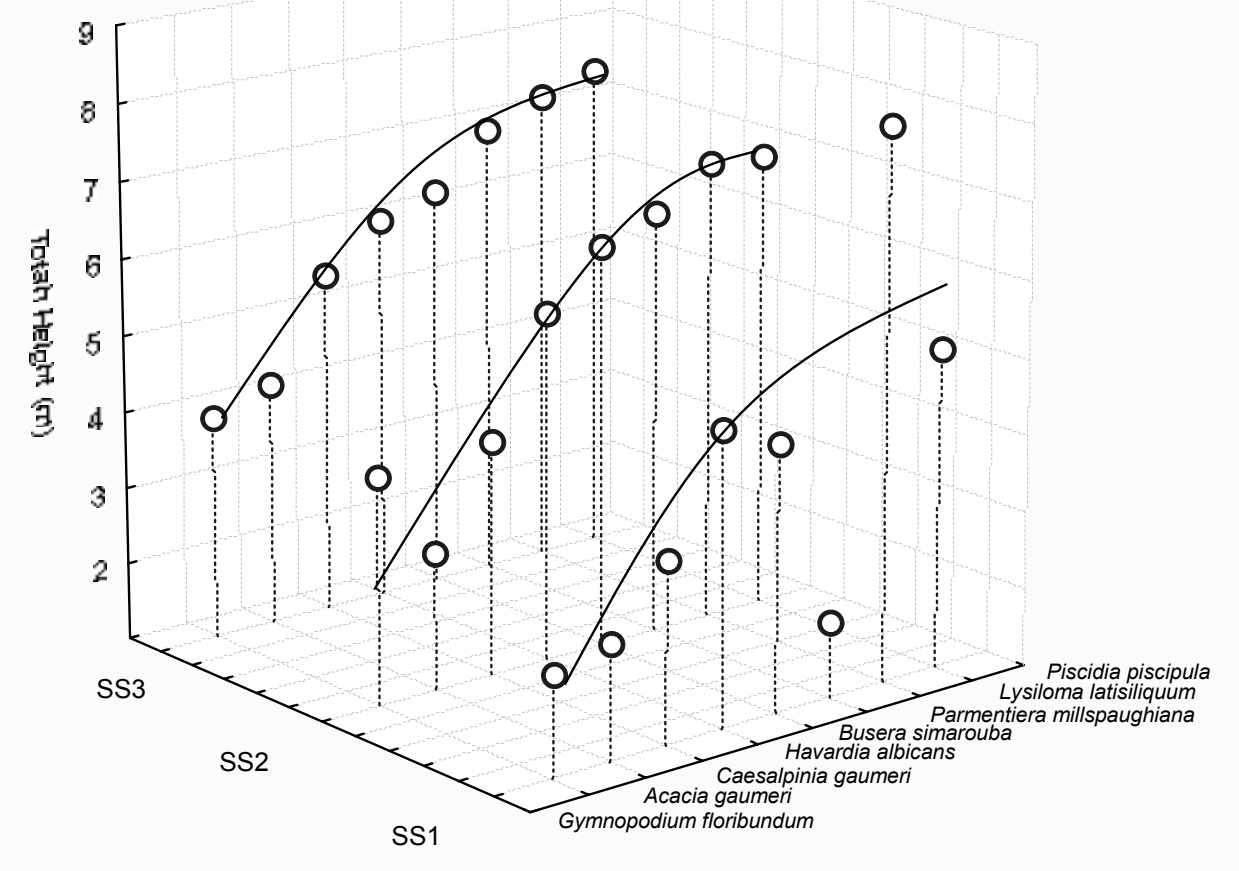

Fig 2-11 Mean Total Height (m) of some tree species at different succession stages. 
Table 2-5. Aboveground biomass of trees in in young, intermediate and mature dry secondary forest in Northern Yucatan.

\begin{tabular}{|c|c|c|c|c|c|c|}
\hline \multirow[b]{2}{*}{ DBH group } & \multirow[b]{2}{*}{ Succession Stage * } & \multirow[b]{2}{*}{ Specie } & \multicolumn{4}{|c|}{ Biomass ** (kg/tree) } \\
\hline & & & Average & $\begin{array}{l}\text { Standard } \\
\text { Deviation }\end{array}$ & Min & $\operatorname{Max}$ \\
\hline \multirow{15}{*}{$\begin{array}{l}\text { Large trees } \\
(>8 \mathrm{~cm} \mathrm{dbh})\end{array}$} & \multirow{5}{*}{ SS1 } & Simarouba glauca & 44.5 & 16.5 & 20.5 & 66.0 \\
\hline & & Piscidia piscipula & 44.3 & 27.9 & 34.3 & 113.9 \\
\hline & & Lysiloma latisiliquum (L.) Benth & 65.4 & 24.9 & 31.1 & 108.8 \\
\hline & & Havardia albicans Britton y Rose & 35.8 & 17.2 & 13.0 & 77.3 \\
\hline & & Caesalpinia gaumeri Greenm & 31.1 & 7.4 & 16.3 & 32.5 \\
\hline & \multirow{5}{*}{$\mathrm{SS} 2$} & Piscidia piscipula & 69.5 & 110.2 & 26.1 & 545.1 \\
\hline & & Lysiloma latisiliquum (L.) Benth & 65.1 & 44.6 & 33.6 & 200.9 \\
\hline & & Havardia albicans Britton y Rose & 42.6 & 19.8 & 38.7 & 65.4 \\
\hline & & Exostema caribaeum (jacq.) Roem. \& Schultes & 58.9 & 49.8 & 32.9 & 94.1 \\
\hline & & Busera simarouba & 50.2 & 31.9 & 35.2 & 215.8 \\
\hline & \multirow{5}{*}{$\mathrm{SS} 3$} & Platymiscium yucatanum & 84.0 & 43.0 & 69.0 & 207.3 \\
\hline & & Piscidia piscipula & 74.9 & 56.2 & 29.5 & 177.3 \\
\hline & & Coccoloba spicata Lundell & 78.3 & 42.1 & 28.9 & 289.5 \\
\hline & & Ceiba aesculfolia (H.B. \& K. Britton \& Baker) & 76.0 & 43.9 & 51.3 & 173.5 \\
\hline & & Busera simarouba & 76.8 & 77.5 & 76.0 & 552.9 \\
\hline \multirow{15}{*}{$\begin{array}{l}\text { Small trees } \\
(<8 \mathrm{~cm} \mathrm{dbh})\end{array}$} & \multirow{5}{*}{ SS1 } & Piscidia piscipula & 4.0 & 1.3 & 0.4 & 5.5 \\
\hline & & Havardia albicans Britton y Rose & 0.9 & 7.7 & 0.3 & 26.5 \\
\hline & & Harpalyce arborescens & 1.0 & 1.3 & 0.5 & 6.9 \\
\hline & & Caesalpinia gaumeri Greenm & 3.1 & 4.0 & 0.3 & 11.8 \\
\hline & & Busera simarouba & 5.2 & 7.0 & 0.5 & 21.4 \\
\hline & \multirow{5}{*}{$\mathrm{SS} 2$} & Senna peralteana (H.B. \& K.) Irwin \& Barneby & 3.8 & 3.5 & 0.9 & 8.9 \\
\hline & & Piscidia piscipula & 6.3 & 6.5 & 0.9 & 15.1 \\
\hline & & Neea psychotrioides Donn. Smith & 2.6 & 3.0 & 0.4 & 9.6 \\
\hline & & Gymnopodium floribundum Rolfe var. Reko & 2.3 & 2.3 & 0.5 & 6.7 \\
\hline & & Busera simarouba & 10.7 & 9.7 & 0.7 & 23.8 \\
\hline & \multirow{5}{*}{ SS3 } & Piscidia piscipula & 10.7 & 11.2 & 4.1 & 26.5 \\
\hline & & Lysiloma latisiliquum & 11.7 & 14.0 & 4.4 & 21.6 \\
\hline & & Karwinskia calderoni & 11.1 & 7.3 & 1.8 & 15.6 \\
\hline & & Havardia albicans Britton y Rose & 12.1 & 5.4 & 11.7 & 17.0 \\
\hline & & Busera simarouba & 6.4 & 7.5 & 2.4 & 21.4 \\
\hline
\end{tabular}

** Equation is $\mathrm{Y}=\operatorname{expf}\{-1,996+2,32 \ln (\mathrm{D})\}$, where $\mathrm{Y}$ is the biomass $(\mathrm{kg} /$ dryweight $)$ and $\mathrm{D}$ the $\mathrm{dbh}(\mathrm{cm})$.

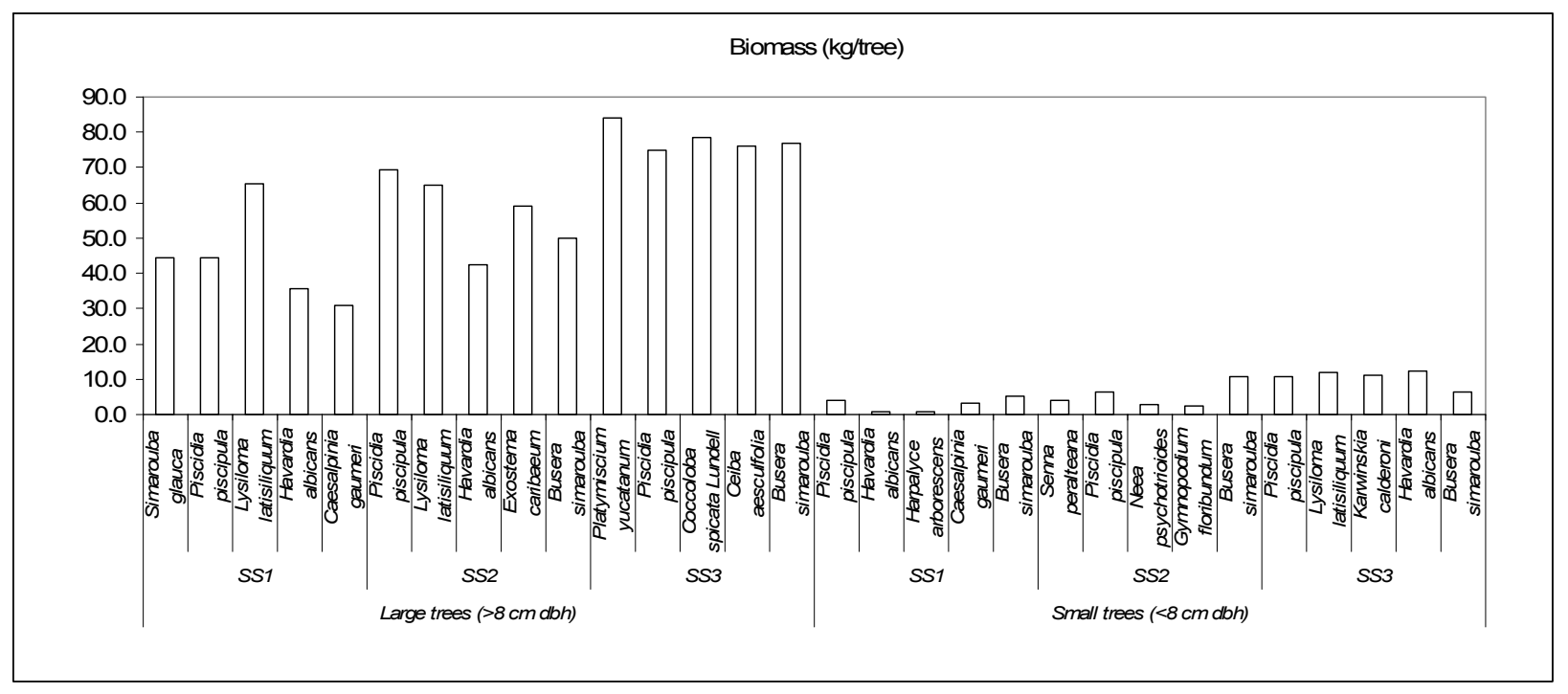

Fig 2-12. Biomass of most frequency species in young, intermediate and mature dry secondary forest in Northern Yucatan. 
Table 2-6. Biomass ( $\mathrm{Mg} / \mathrm{ha})$ in young, intermediate and mature dry secondary forest in Northern Yucatan.

\begin{tabular}{ccc}
\hline DBH group & Succession Stage * & Biomass ** (Mg/ha) \\
& & Average \\
\hline \multirow{2}{*}{ Large trees $(>8 \mathrm{~cm} \mathrm{dbh})$} & $\mathrm{SS} 1$ & 13.23 \\
& $\mathrm{SS} 2$ & 19.72 \\
& $\mathrm{SS} 3$ & 36.92 \\
Small trees $(<8 \mathrm{~cm} \mathrm{dbh})$ & $\mathrm{SS} 1$ & 23.92 \\
& $\mathrm{SS} 2$ & 30.55 \\
& $\mathrm{SS} 3$ & 37.69 \\
\hline
\end{tabular}

* SS1 (<10 yr), SS2 (10 - $20 \mathrm{yr}), \operatorname{SS} 3(>20 \mathrm{yr})$

** Equation is $\mathrm{Y}=\exp \{-1.996+2.32 * \ln (\mathrm{D})\}$, where $\mathrm{Y}$ is the biomass $(\mathrm{kg} /$ dryweight $)$ and $\mathrm{D}$ the $\mathrm{dbh}(\mathrm{cm})$.

The forest composition and basal area are similar to other forests of this type (Gonzalez-Iturbe et al. 2002, Mizrahi et al. ,1996, Olmsted and Duran, 1984; Whigham et al., 1991) in the same region.

The aboveground biomass varies from 13.2 to $36.9 \mathrm{Mg} /$ ha for individuals with $\mathrm{dbh}>$ $8 \mathrm{~cm}$, combined with the biomass for individuals with $\mathrm{dbh}<8 \mathrm{~cm} \mathrm{~cm}$ (23.9 to 37.6 $\mathrm{Mg} / \mathrm{ha}$ ) of aboveground biomass, totals 37.1 to $74.6 \mathrm{Mg} / \mathrm{ha}$ (Table 2-5).

The latter is similar the aboveground biomass calculated by Cairns et al. (2000) and cited by Lawence et al. (2004) for the semi-evergreen tall/medium forest in the three stages of the Yucatan Peninsula (111.2 Mg/ha).

The biomass of the small trees $(33.5 \mathrm{Mg} / \mathrm{ha})$ comprises approximately $15 \%$ of the total biomass $(225 \mathrm{Mg} / \mathrm{ha})$ in this forest (Table 3). Although 18 of the 213 trees used to compute the large tree biomass density $(8 \%)$ were not harvested, the un-cut trees were of the same species, and approximately within the same size distribution, as the harvested trees. Only one tree, a Ficus sp. with a dbh of $82.1 \mathrm{~cm}$, was outside the range of the destructive harvest, and would not significantly change the biomass density estimate. 
Separation of the individual trees into two size groups with separate allometric equations may enable calculation of more precise biomass estimates reflecting changes in geometric growth forms as trees age.

The use of the species-specific equations (Table 2-6) for the dominant trees enables accurate estimates of aboveground tree biomass in other mature and successional forests located elsewhere. There is a need for biomass estimates for reliable methods of measuring environmental services such as $\mathrm{C}$ sequestration.

Martínez-Yr zar (1995) reported biomass densities for 15 different dry forests which range in precipitation from 500 to $1500 \mathrm{~mm}$ per year. The aboveground biomass ranges from 23 to $268 \mathrm{Mg} / \mathrm{ha}$, with 12 of the 15 sites less than $144 \mathrm{Mg} / \mathrm{ha}$. Her report for the wettest site, Ping Kong, Thailand $(1500 \mathrm{~mm})$, includes values of both 268 and $144 \mathrm{Mg} / \mathrm{ha}$.

Our measured biomass was near the high end of the range reported by MartínezYrizarr (1995). The only other primary data from Mexican dry forest sites were 85 $\mathrm{Mg} / \mathrm{ha}$ in Chamela, Jalisco (Martínez-Yr zar et al., 1992) and 63 and $85 \mathrm{Mg} / \mathrm{ha}$ for two secondary dry deciduous forests on the Yucatan Peninsula (Lawrence, 2004; Mizrahi et al., 1997).

A graph of above-ground biomass and rainfall presented by Martínez-Yrizar (1995) works well for the lower rainfall ranges $(600-800 \mathrm{~mm})$, but fails above $1000 \mathrm{~mm}$. This suggests that the variability of biomass density in forests receiving between 1000 and $1500 \mathrm{~mm}$ annual rainfall is large.

Allometric equations containing diameter and total height rather than diameter alone, when applied to the most abundant species (Table 2-6), produced biomass estimates closest to the actual weight and should therefore be used for these species in other biomass studies at other locations. Accuracy may be compromised if our dbh2 total height equation including all species is employed in a similar forest where the 
diameter distribution is similar, but where the species have shorter relative heights. Soil differences may bring about such reversals (Gonzalez-Iturbe et al., 2002). In these situations, a regression model containing only diameters would provide a more accurate biomass estimate.

The allometric equation used above for the determination of biomass for dry semievergreen forests and their individual species may allow land managers to make more informed decisions regarding the harvesting and forestation of land suitable for tree growth. Wise management practices and resource conservation may be enacted through a consideration of environmental services such as $\mathrm{C}$ sequestration. If global $\mathrm{C}$ markets become a reality, reliable methods useful for estimation of source/sink potential will be required.

\section{Differences between black and red soils at different forest ages}

Due to extreme heterogeneity of the soils it was essential to understand how the two principal soil types affect soil properties before the effects of age could be examined. We divide samples into two groups. Red and Black soils based on Munsell color. The typical colors of black Tsekel (Leptosol) were 10YR3/3, 10YR3/2 and 10YR2/2 found at the Munsell Chart. The color of red Kankab (Cambisol) was typically 7.5YR2.5/3. The sites with red Cambisol were normally situated in the plain.

The differences between both soils are their mineralogy. Humus-rich soils are shallow soils, forming from clay-marl and have primary carbonates through out the soil profile (Aguila, 2007).

Analyzing results of the Organic $\mathrm{C}$ and total $\mathrm{N}$ concentrations in mineral soils there are significant differences $(\mathrm{p}<0.001)$ between black and red soils as shown in Figure 2-13. Organic $\mathrm{C}$ and Total $\mathrm{N}$ were approximately $50 \%$ in the red soil as reported by Weisbach et al. (2002). 


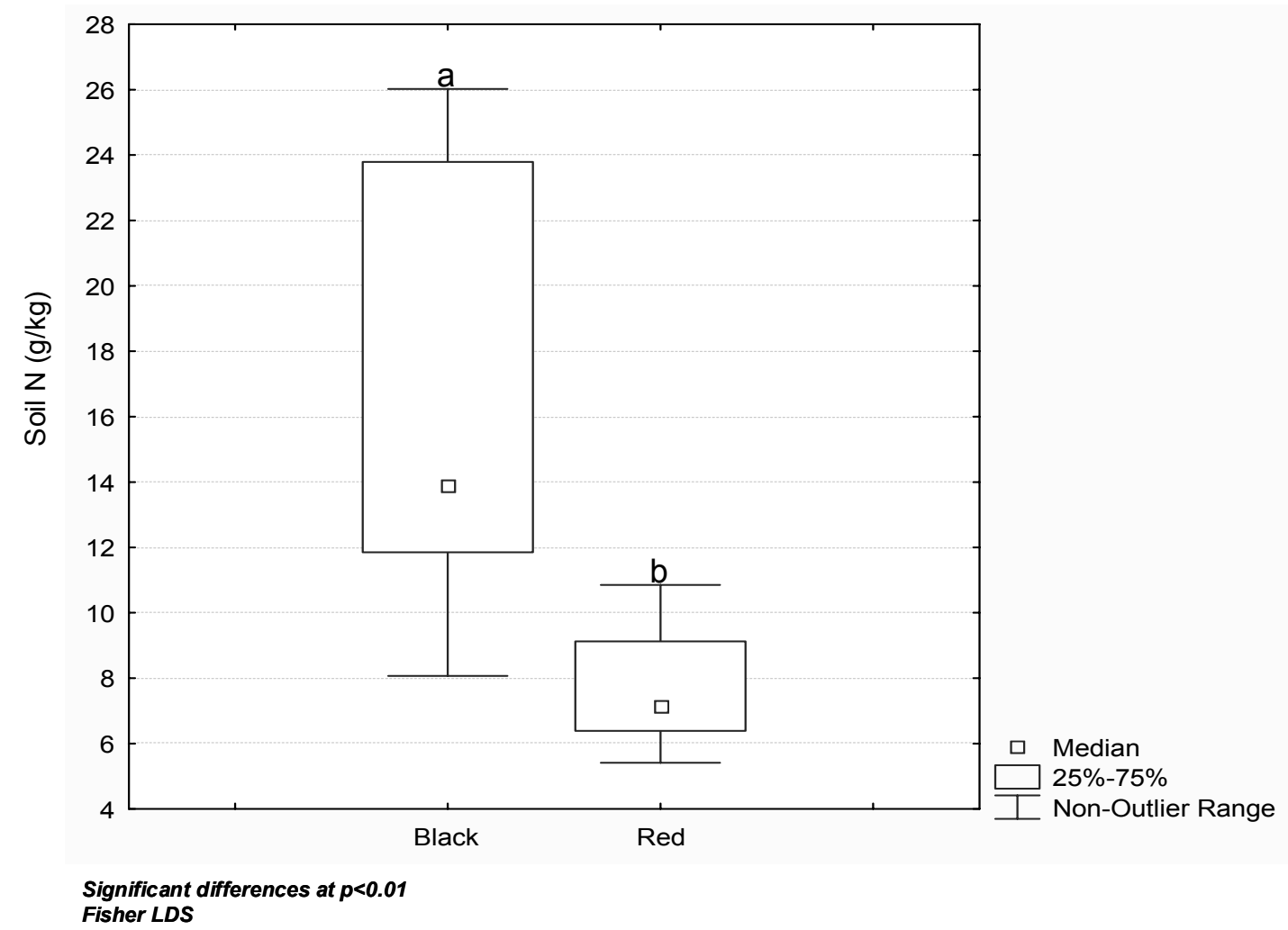

Figure 2-13. Significant differences between N-black and N-red soils. Numbers followed by the same letter are No significantly different by Fisher LSD at $\mathrm{p}<0.05$.

Results show strong differences between both Yucatec soils. Beach (1998) and Aguila (2007) reported large differences between red and black soils from northwest Yucatan. These authors reported $0.7 \% \mathrm{CaCO}_{3}$ and $0.24 \% \mathrm{CaMg}\left(\mathrm{CO}_{3}\right)_{2}$ content in red soils, whereas the black group presented $2.8 \% \mathrm{CaCO}_{3}$ and $7.6 \% \mathrm{CaMg}\left(\mathrm{CO}_{3}\right)_{2}$ content. Weisbach et al. (2002) studied the Differences between black and red soils at different forest age effect of fallow cycle on soil fertility in these Mexican soils. They also reported differences between black and red soils in OC, N, and carbonate contents. On average, black soils presents 54\% more OC, $48 \%$ more N, and $69 \%$ more carbonates than red soils. These authors also found that organic matter content was reduced in both Yucatec soils after the end of the fallow cycle (12 yr). This depletion accounted for $30 \%$ of OC and $20 \%$ of $\mathrm{N}$ in red soils, whereas in the black group OC and $\mathrm{N}$ were reduced by 26 and $21 \%$, respectively. The large accumulation of SOM in black soils under fallow indicated that decomposition may be limited in these soils. It has been assumed that, even in semiarid areas, rates of SOM turnover 
and mineralization are generally greater in tropical than in temperate soils (Shang and Tiessen, 2000). However, Echenique (2005) suggested that the extremely high carbonate content in these soils may be acting as a factor of stabilization impeding its mineralization, which may influence negatively nutrient availability for plants.

The pre-treatment of soil samples with concentrate $\mathrm{HCl}$ fumes complemented with the acid wash was effective to remove carbonates from the highly calcareous samples collected in calcareous soils without altering the organic matter. Maintaining soil samples wet during the fumigation was the principal difficulty to cope with during the procedure. Specifically for the soils of semiarid regions (calcareous), black ones were more problematic because they have more carbonate content than red. Values of $\mathrm{C} / \mathrm{N}$ ratio indicated that organic materials were not affected by the acid treatment.

In our investigations we found that Total Carbon (TC), Organic Carbon (OC), and N content in soils were related to forest age (Figure 2-14). The black soils from SS3 forests presented the highest $\mathrm{OC}$ and $\mathrm{N}$, followed by the black soils from SS2 and SS1. Red soils had less TC, OC and N compared to the black ones, independently of the forest age adopted. The $\mathrm{C} / \mathrm{N}$ ratios for $\mathrm{OC}$ varied among the different sites, ranging from 8.4 to 10.3 .

Significant differences were found among forest age for OC (ANOVA, $\mathrm{p}>0,05$ ). Carbonate content in Mexican soils was about 70\% higher in black soils than in the red group similar to what was reported by Aguila (2007).

The differences between red and black forest for $\mathrm{N}$ were less pronounced than in SS1 in comparison with SS3. No significant differences were found among forest age for $\mathrm{N}$ (ANOVA, $\mathrm{p}>0,05)$ in red forest but significant differences were found between SS1 and SS3. 


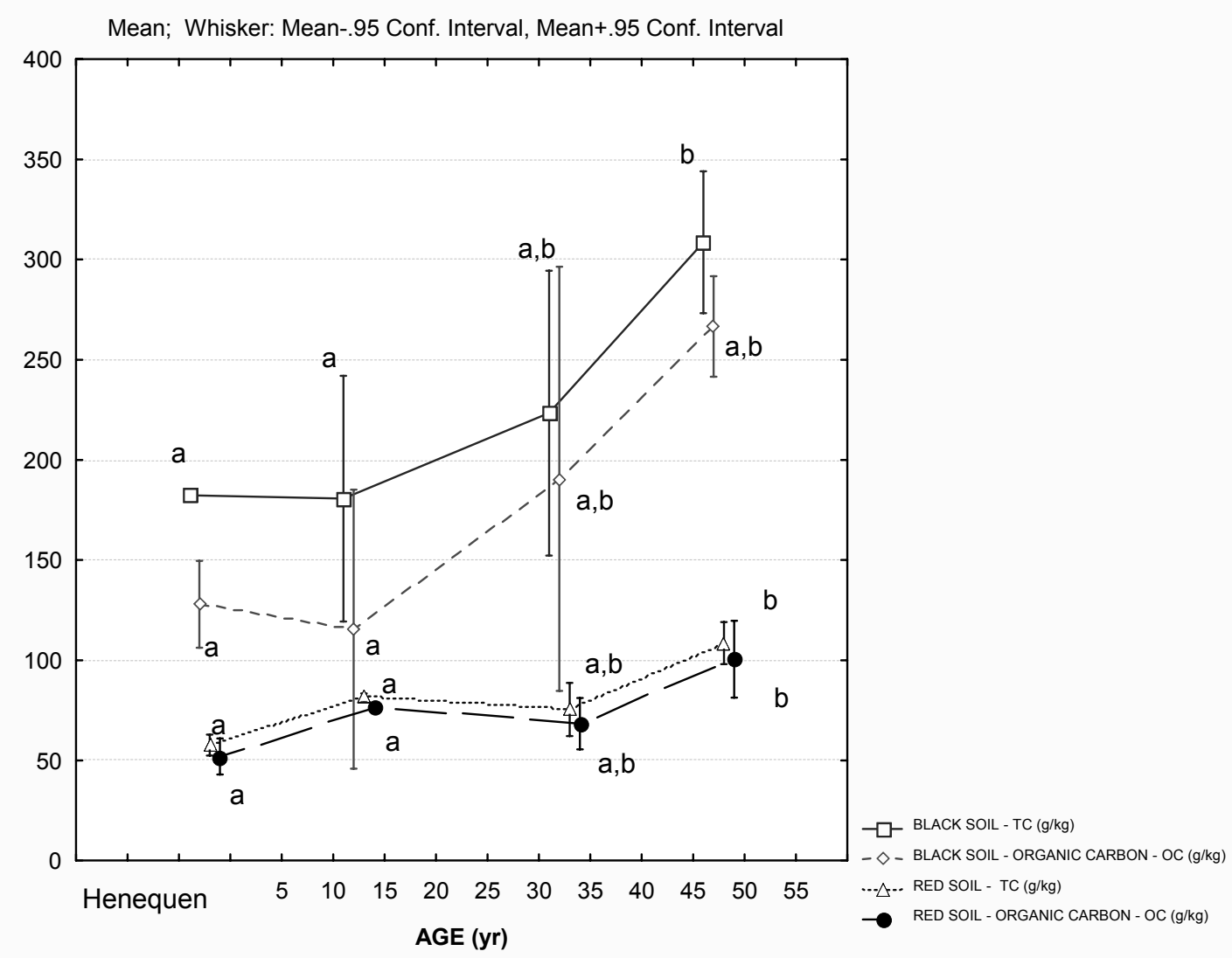

Figure 2-14. C-black and C-red at different forest age. Numbers followed by the same letter are No significantly different by Fisher LSD at $\mathrm{P}<0.05$.

The higher $\mathrm{C}$ and $\mathrm{N}$ contents in SS3 forest areas may be attributed to litterfall. In SS3, litterfall accumulation is higher than in the SS2 and SS1 forest. Litterfall has been recognized as the main pathways for nutrient cycling in semiarid forests, because its nutrients may be decomposed and cycled several times in a year (Vitousek, 1984, Aguila 2007). However, Markewitz et al. (2004) explain that, in some tropical ecosystems, grass turnover may substitute litterfall return as the predominant pathway of nutrient cycling. 


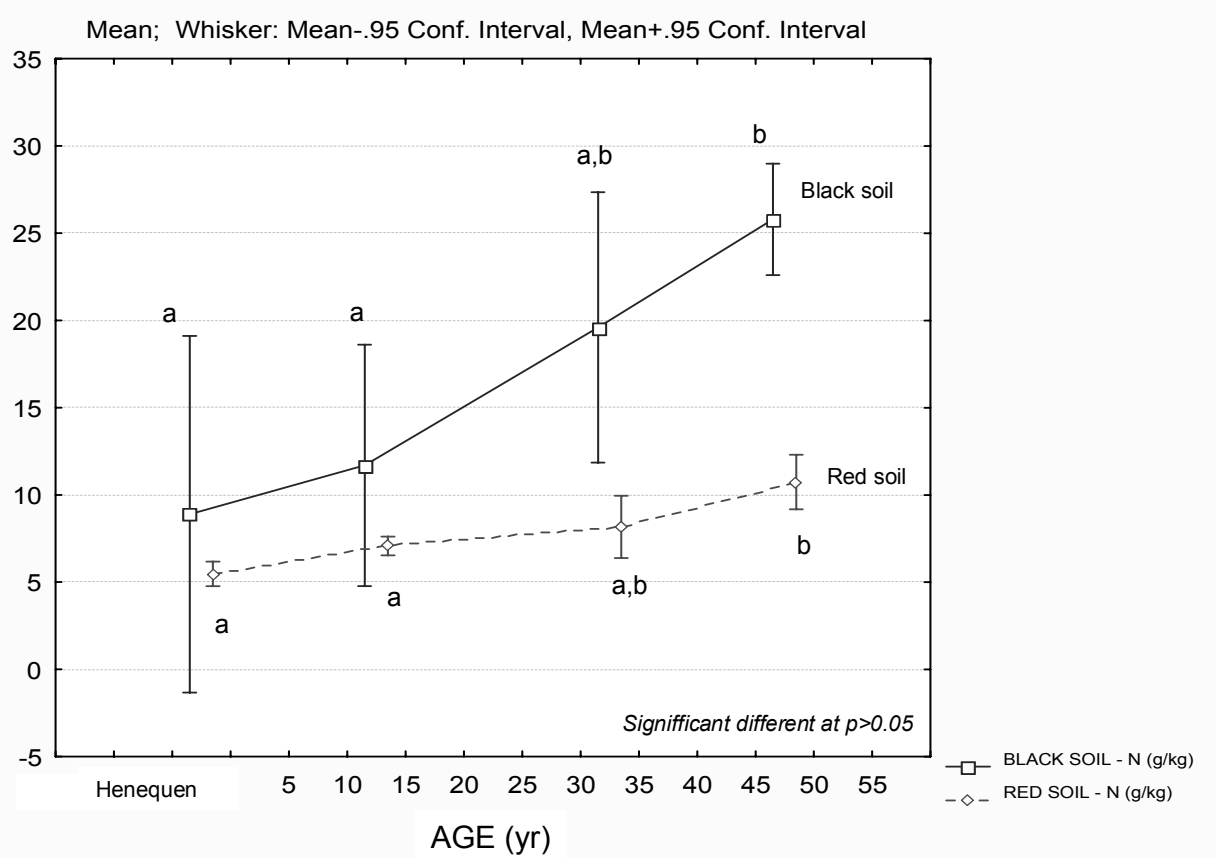

Figure 2-15. N-black and N-red soils at different forest age. Numbers followed by the same letter are No significantly different by Fisher LSD at $\mathrm{p}<0.05$.

These differences in previous land use and the time under the present farming systems explain the contrast between these sites. Echenique (2005) reported that pastures implementation may have a minimal impact or can increase SOM content. The amount and quality of both above- and below-ground biomass incorporated to the SOM can contribute to maintain OC content with time (Echenique, 2005). Aguila (2007) has cited Vargas et al. (2003) who studied OM content at two depths (0-10 am and 10-20 cm) in brown calcareous soils from Santa Clara (in Cuba) with different land uses (sugarcane, pasture, and legume-forage fields). They found that the natural grassland and the legume-forage field had higher OM content than the sugarcane area at both depths. Their results suggested that either natural or artificial grassland may preserve higher SOM and OC stocks than areas under intensive agriculture.

In Yucatan, red soils are preferred by the farmers for cropping because they are easier to work than the black ones (Weisbach et al., 2002; Aguila, 2007), so they had more losses in OC and $\mathrm{N}$ compared to black soils over the cultivation cycle. 


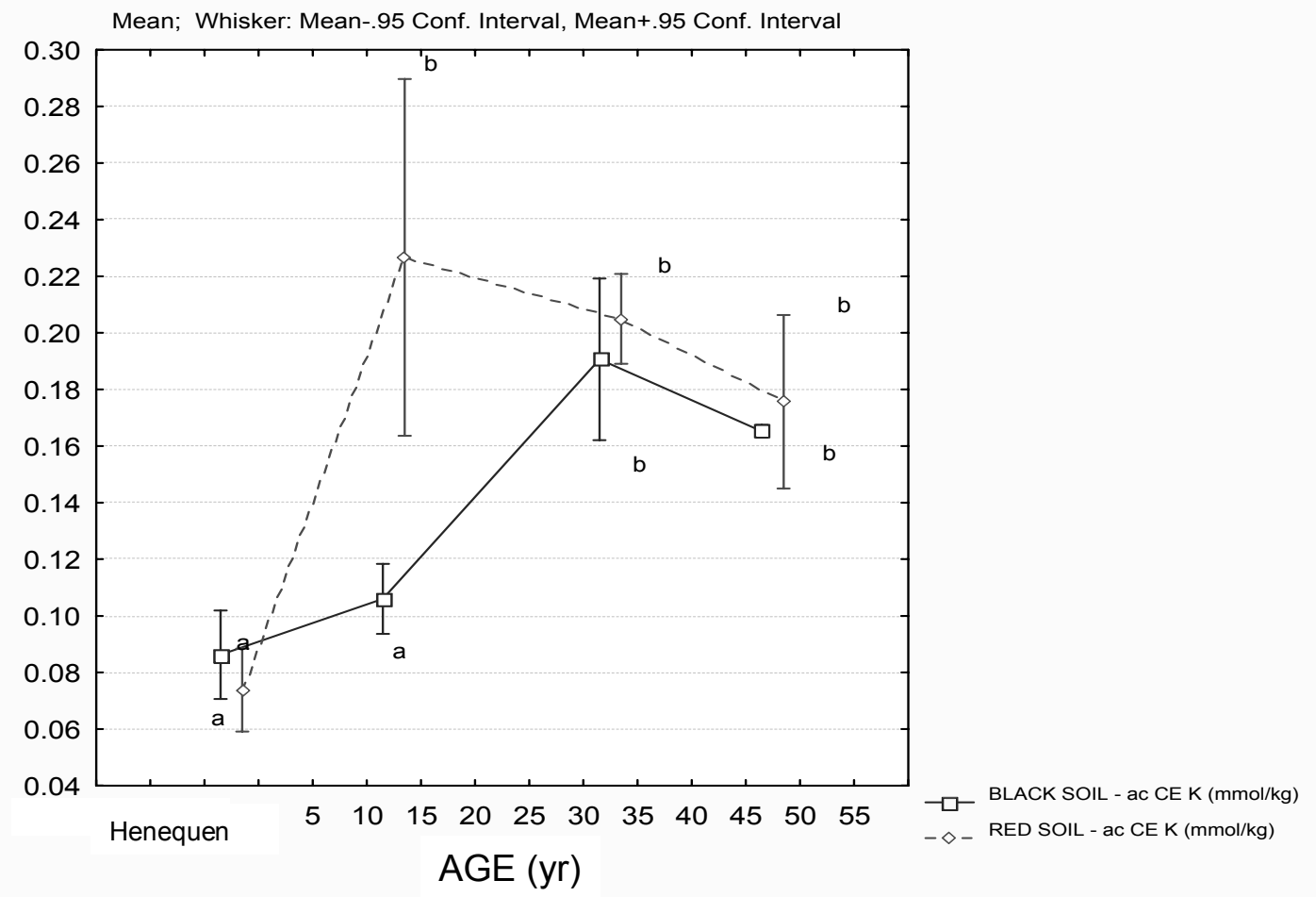

Figure 2-16. CE K-black and CE K-red soils at different forest age. Numbers followed by the same letter are No significantly different by Fisher LSD at $p<0.05$.

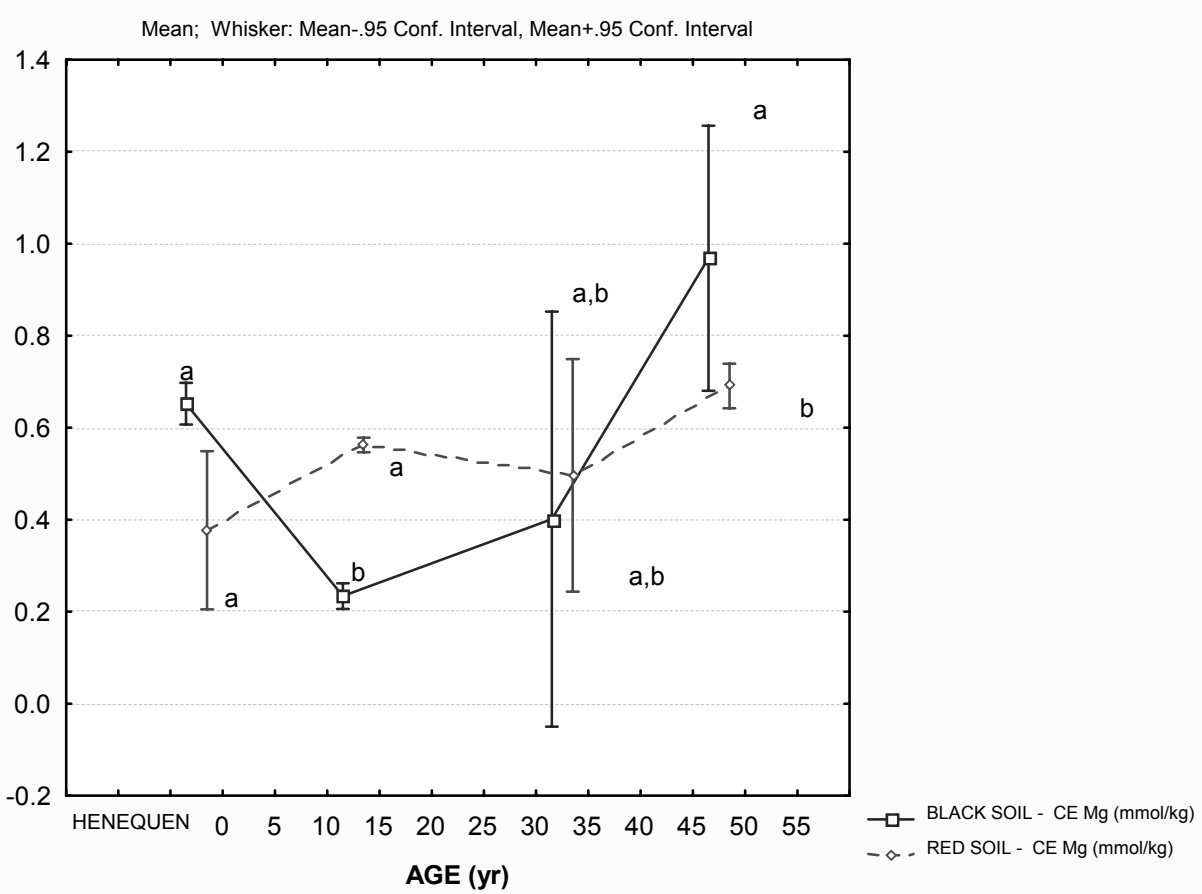

Figure 2-17. CE Mg-black and CE Mg-red soils at different forest age. Numbers followed by the same letter are No significantly different by Fisher LSD at $\mathrm{p}<0.05$. 


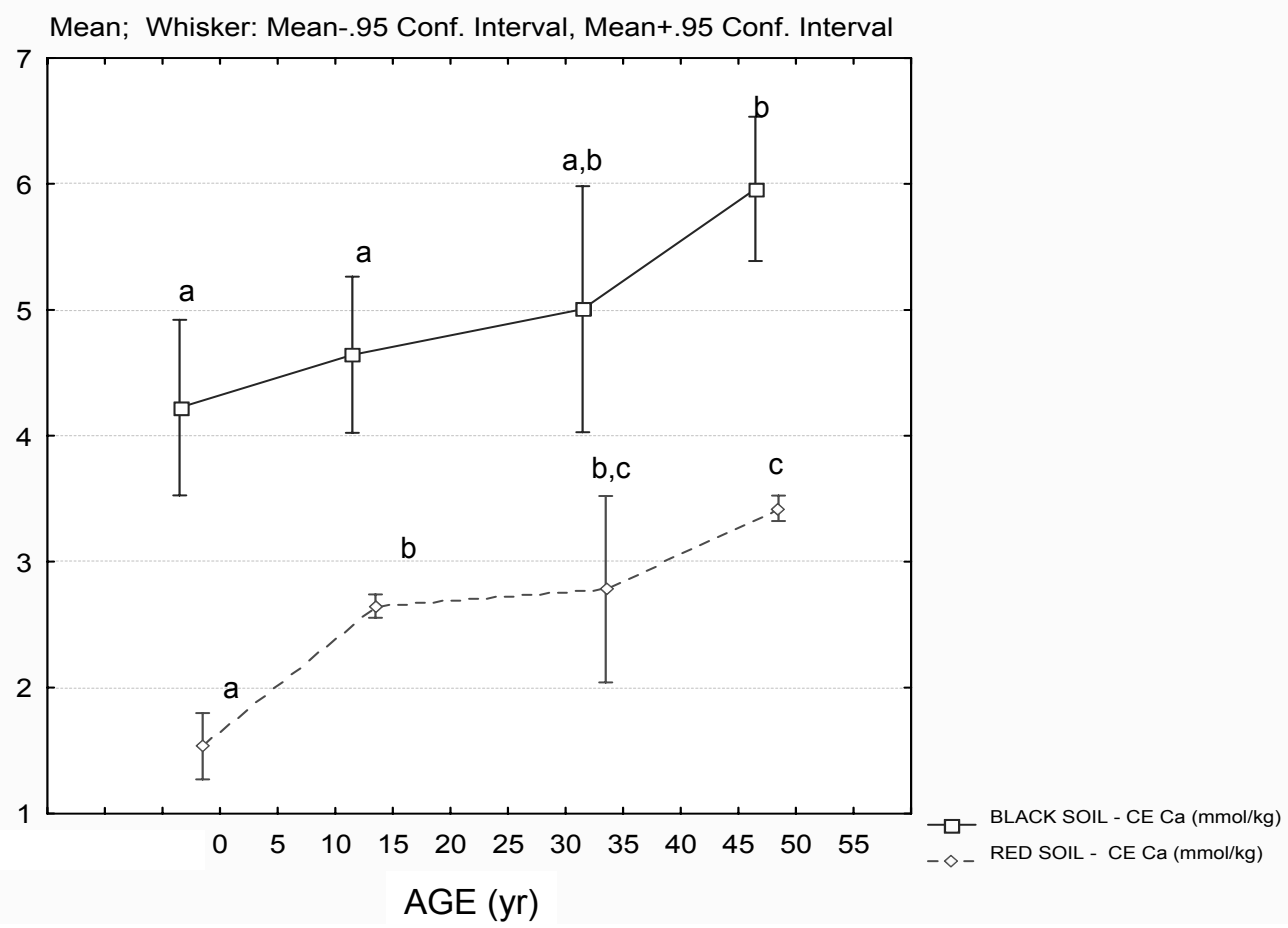

Figure 2-18. CE Ca-black and CE Ca-red soils at different forest age. Numbers followed by the same letter are No significantly different by Fisher LSD at $\mathrm{p}<0.05$.

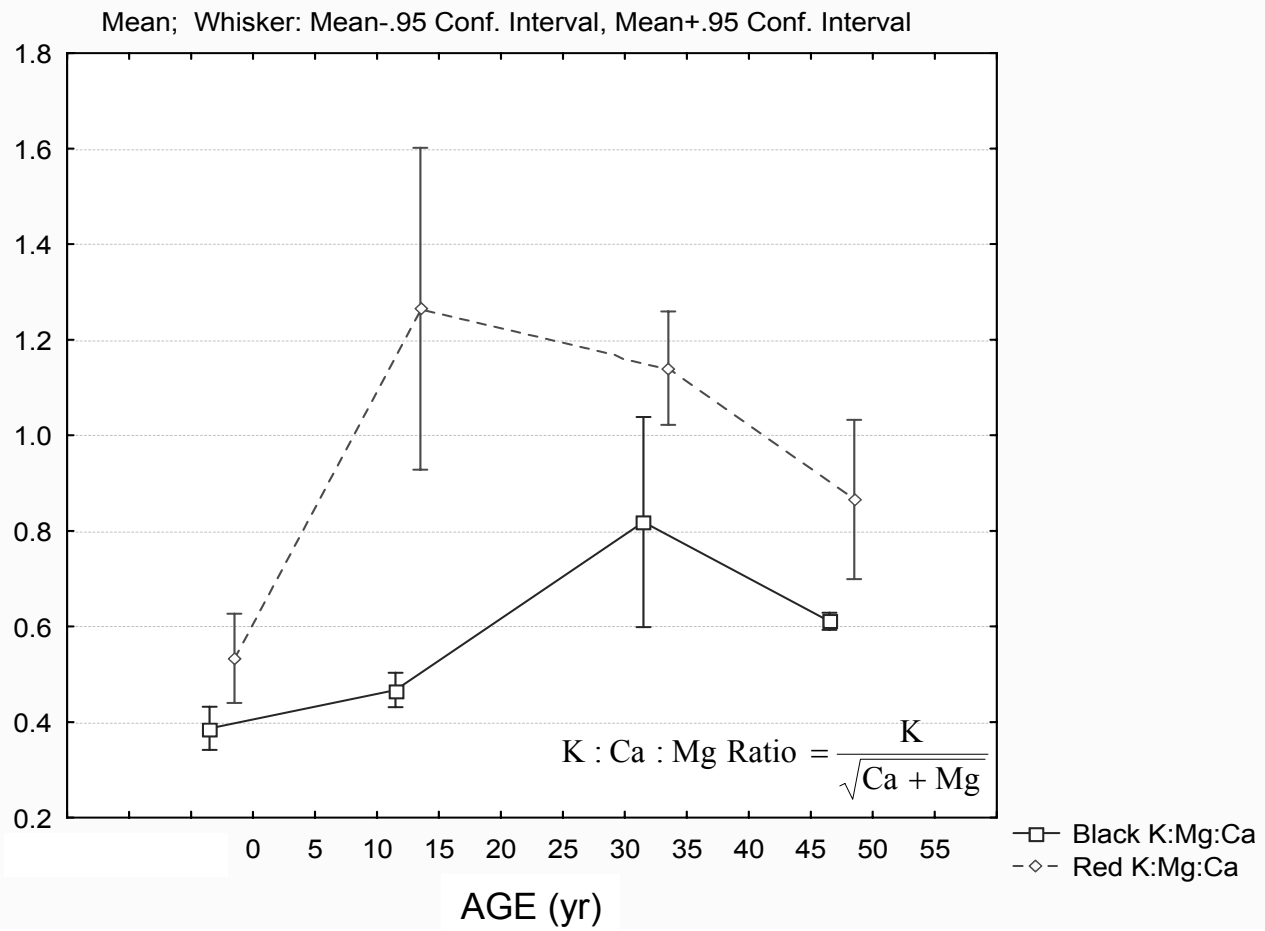

Figure 2-19. K:Mg:Ca ratios in black and red soils. Numbers followed by the same letter are No significantly different by Fisher LSD at $\mathrm{p}<0.05$. 
Land use, forest age and soil type affected K availability in sampled soils (Figure 216). On average, less potassium contain was observed in red soils than in black soils.

The intermediate succession stage SS2 areas presented the highest availability of K. This results in $\mathrm{K}$ trends shows that internal nutrient cycling might be an important conservation mechanism exhibited by late secondary vegetation.

Magnesium (Mg) concentrations (Figure 2-17) were affected land use, forest age and soil type. In general, the availability of $\mathrm{Mg}$ was higher in mature forests (SS3) although no significant differences were found between different forest ages.

Soils presented significant differences in calcium availability (Figure 2-18). Among land uses, forest presented the highest levels of Calcium as the forest growth (SS2 and SS3) and a clear difference in calcium content can be observed between the red and black soils. Less calcium concentration was observed in red soils than in black soils.

According to Aguila (2007), low values of available potassium result from the competition among the three cations $(\mathrm{Ca}, \mathrm{Mg}$, and $\mathrm{K})$. High levels of available calcium may suppress $\mathrm{Mg}$ and $\mathrm{K}$ uptake by plants. It has been reported that when calcium availability exceeds $80 \%$, the proportion of available magnesium is low (less than $4 \%$ ), and also potassium decrease due to the competition among the cations (Hagin and Tucker, 1982, and Marschner, 1995 in Imas, 2000).

\section{Concentrations of elements in leaf and litter}

In contrast with other ecosystems with the same plant diversity and structure, litter input to soil in Yucatec forest is low. One probable reason may be the water availability that limits microfauna activity, which made inefficient the nutrient cycling. 
The litter mass increased rapidly during the later stage throughout the 40-50 years age sequence of communities, to reach a maximum mean biomass of 20-24 ton/ha. This is similar to the accumulation of $11,9-44,6$ ton/ha forest floor material reported by Montañez, E. (1998) in the area of Hocaba and Sahcaba.

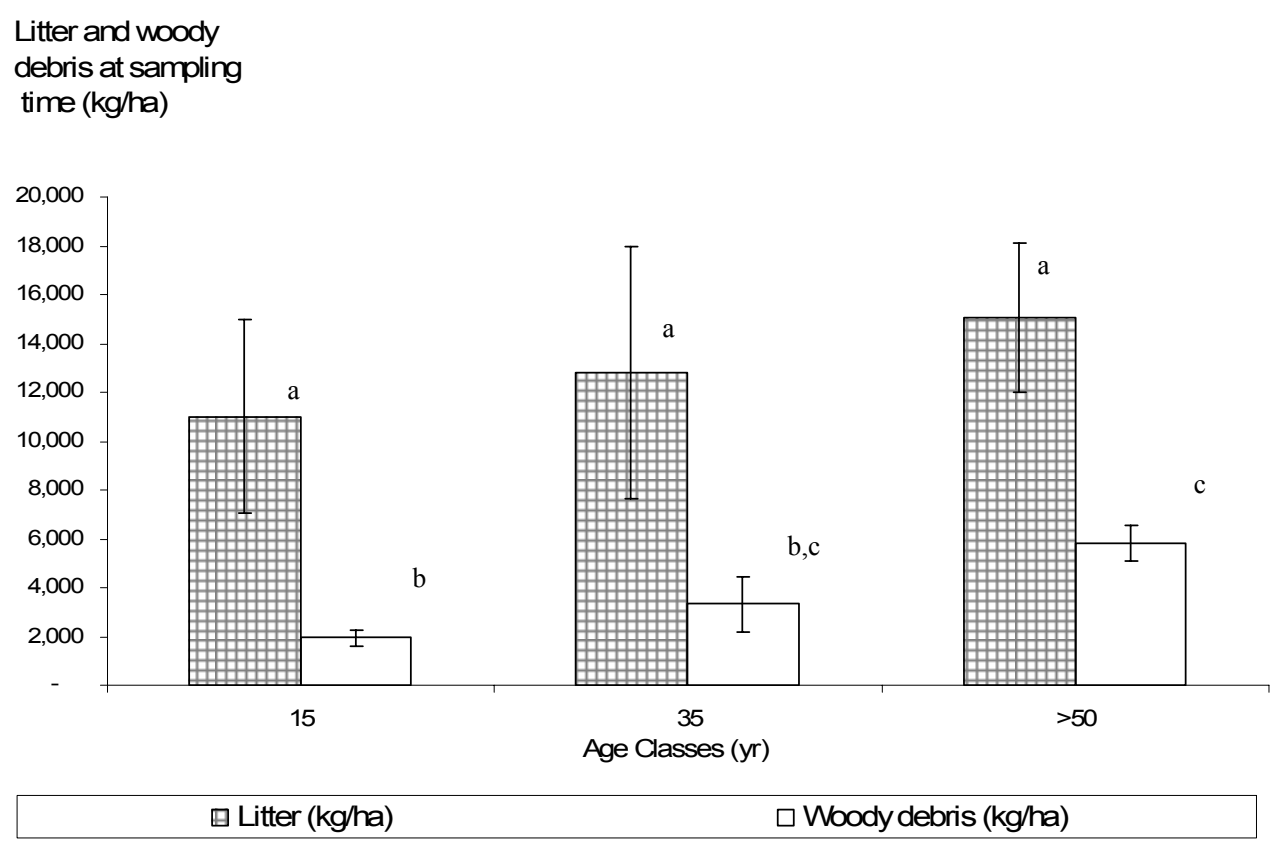

Fig 2-20. Litter and small branches at sampling time at different forest age classes. Numbers followed by the same letter are No significantly different by Fisher LSD at $\mathrm{p}<0.05$.

Thus, the observed increase in forest floor biomass suggests a concomitant increase in litter production along the forest age. Mean litter production was greater in old forest, but the result was not statistically significant due to small sample size and high variability. Martínez-Yrizar and Sarukhan (1990) found higher litter production in the moister of their two study sites in Chamela, Mexico. 


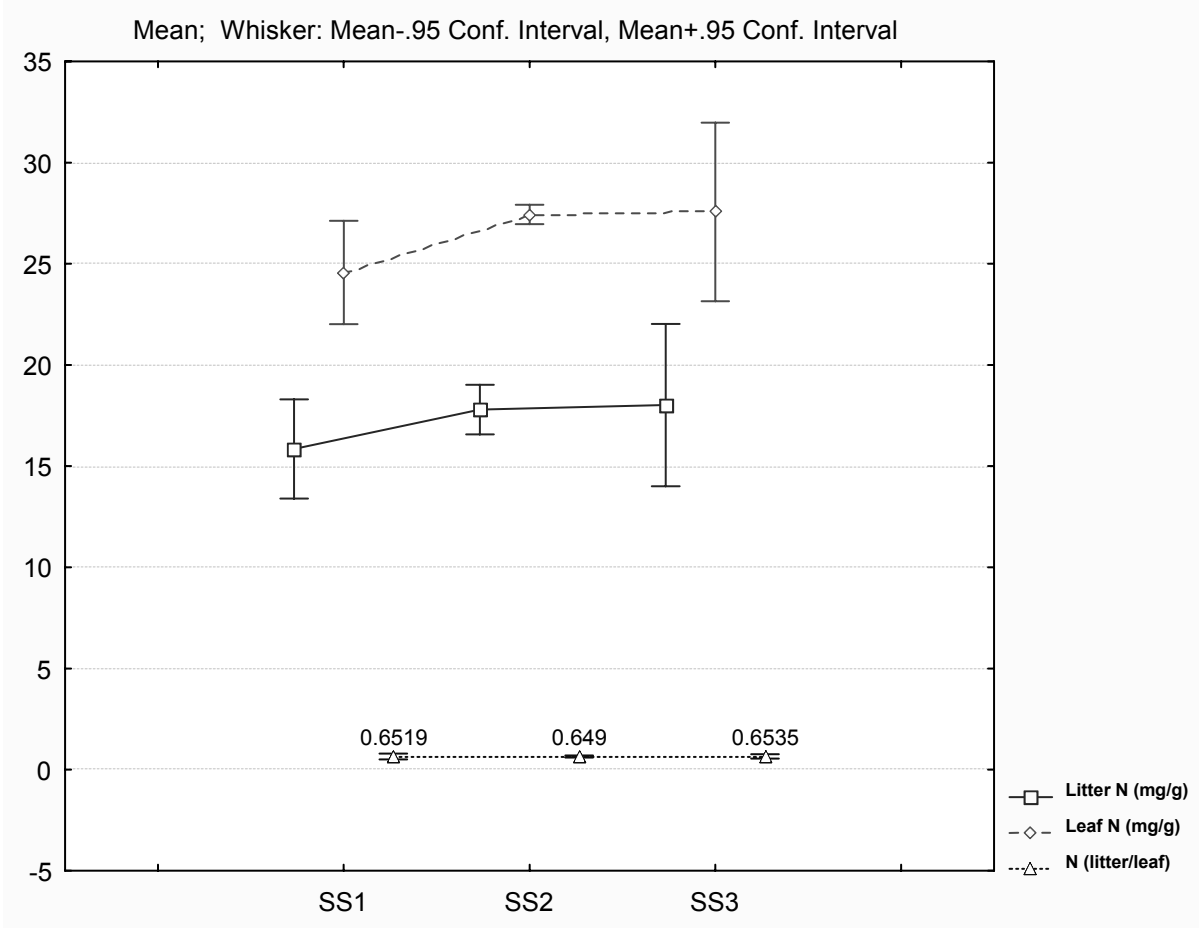

Figure 2-21. N-litter, N-leaf and N litter and leaf ratio. No significantly differences were found along the succession stage (Fisher LSD at $\mathrm{p}<0.05$ ).

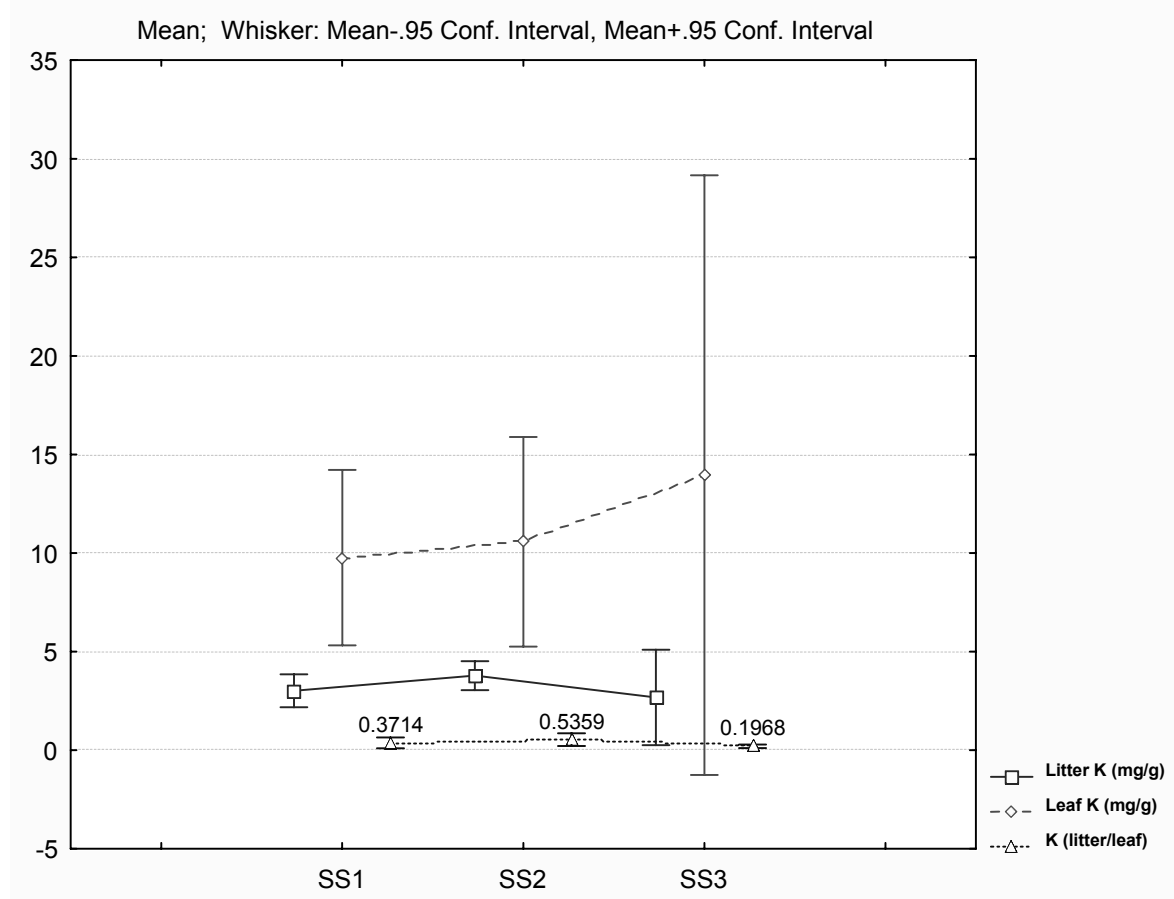

Fig 2-22. $\mathrm{K}(\mathrm{mg} / \mathrm{g})$ in leaf and litter at different forest age. No significantly differences were found along the succession stage (Fisher LSD at $p<0.05$ ). 


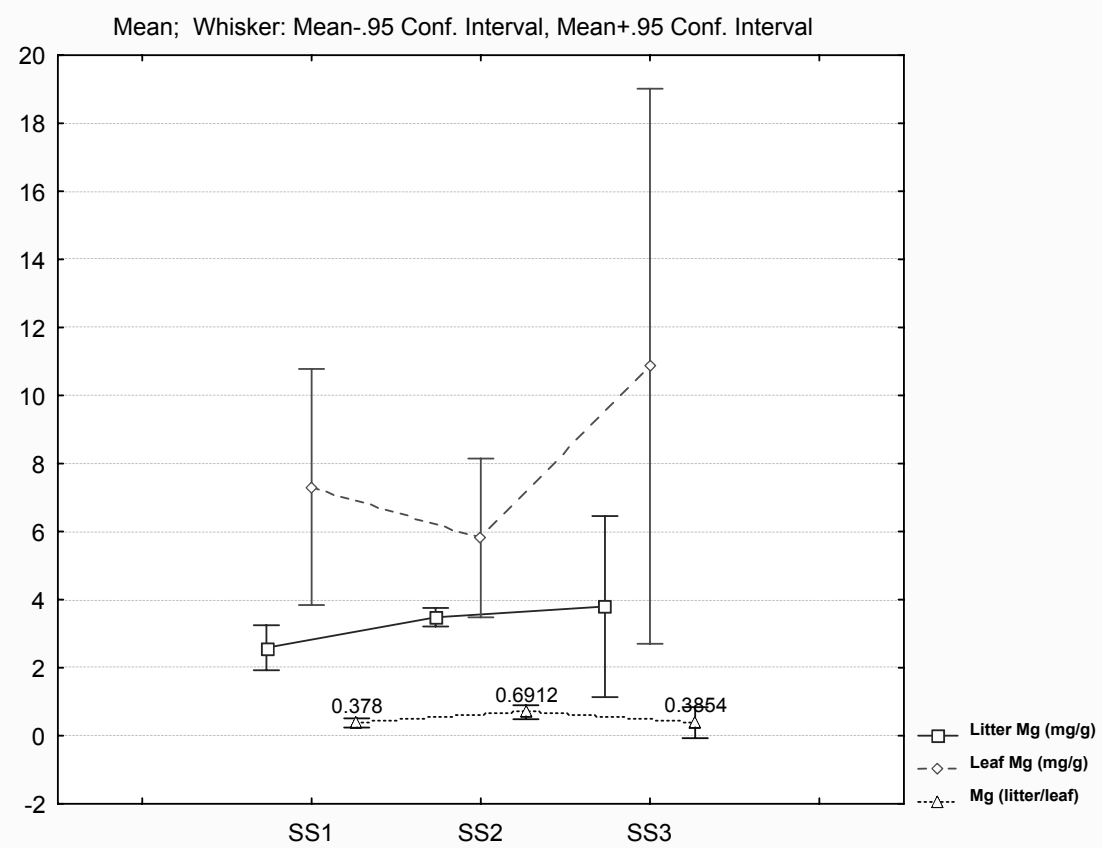

Fig 2-23. $\mathrm{Mg}(\mathrm{mg} / \mathrm{g})$ in leaf and litter at different forest age. No significantly differences were found along the age (Fisher LSD at $p<0.05$ ).

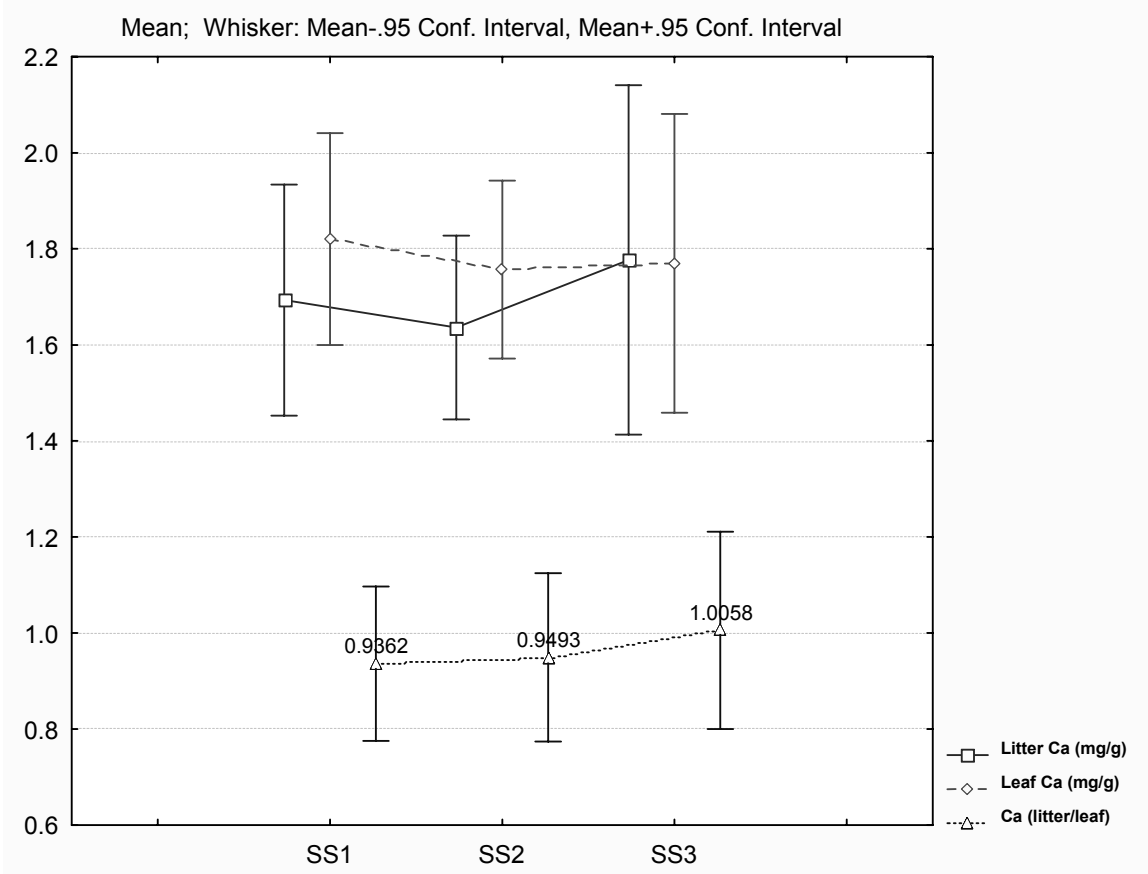

Fig 2-24. Ca (mg/g) in leaf and litter at different forest age. No significantly differences were found along the age (Fisher LSD at $p<0.05$ ). 
Nutrient poor and dry soils will limit rates of succession by limiting leaf area development and aboveground production. Moist, fertile soils that promote high leaf area, net primary production, and aboveground allocation will generally have much faster rates. Litterfall contributes to the buildup of organic matter and eventually the site reaches a condition that can support continues cover of slowly growing closed forest (Bauhus, J. 2003).

Trees influence and are influenced by the forest floor. Since different species thrive on different soils, different trees may have colonized different types of soil at the beginning of succession (Stone, 1975). In contrast, trees may have originated on similar soil and then changed soil properties through time. One method for making the distinction between these two mechanisms is to examine stands of trees that have been manually planted on similar sites. These studies and others show that tree species can significantly influence forest soils particularly in nutrient accumulation (Alban 1982, Zinke 1962, Gower et al. 1992, Scheu 1997, Stump and Binkley 1992).

Trees can influence the soil they grow. One primary factor in soil processes is the quality of leaf litter. Litter quality influences the decomposition and mineralization of the leaf litter and other organic matter in the soil. Tree species on nutrient poor sites may invest low amounts of nutrients in leaves or reabsorb large proportions of nutrients from leaves thus returning low quality leaf litter to the soil (Bockheim and Leide 1991). This inhibits decomposition and fosters immobilization of nutrients possibly resulting in a decrease in site fertility. In contrast, tree species on nutrient rich sites may use greater amounts of nutrients in leaves or reabsorb fewer nutrients thus returning higher quality litter to the soil. This encourages faster decomposition and nutrient cycling, enhancing the site quality (Bockheim and Leide 1991, Hobbie 1992, Vitousek 1982).

Nitrogen and potassium clearly differentiates between leaf and litter material (Figures 2-21 and 2-22). Nitrogen is widely recognized as one of the major factors controlling forest productivity, and is a prominent nutrient found in higher concentrations in metabolically-active tissues like leaves, buds, and seeds (Larcher, 1995). Potassium is soluble and readily leached from organic matter; this is consistent with the observed 
drop in $\mathrm{K}$ concentration from live to decomposing material. They may also be retranslocation of $\mathrm{K}$ prior to abscission.

Calcium shows no clearly differences among leaf and litter material, however, higher concentrations in leaf material was found (Figure 2-23). Trees store this element mainly in leaves and tree bark (Perry, 1994) so this proportion help to explain the higher calcium concentration observed in litter in comparison with nitrogen and potassium.

The decomposition of biomass is usually associated with an increase in elemental concentration by the action of heterotrophic organisms (Staaf and Berg, 1982) particularly if the decaying material is low in nutrient content.

Calcium was also important in distinguishing among leaf and litter, and its ratio was found in higher than in nitrogen and potassium.

Other studies have examined other organic additions to the soils, arguing that these may be as important as leaf litter. Below-ground production is poorly understood, but it may account for up to $60 \%$ of net ecosystem production (Vogt et al., 1992). Mycorrhizae production may account for up to $15 \%$ (Vogt et al., 1992) in a pine forest. The amount of photosynthate lost from roots into the rhizosphere influences the distribution and amount of fungal and bacterial biomass in the soil (Norton and Firestone, 1991). This may be a relatively high (>30\%) amount of the photosynthate transported to the roots (Reid and Mexal, 1977).

However, the possible magnitude of this effect remains uncertain (Norton et al, 1990). Trees can also influence soil properties. For example, they can redistribute minerals in soil, by transporting minerals from deeper soil horizons up to the forest floor (Alban, 1982). These minerals are then more readily available to those same trees and to other vegetation.

Tree species may grow on particular soils because specific trees compete better on certain soils. Thus, tree species that compete best on a particular soil would thrive while others would not. I have not found experiments isolating competition between 
species as a cause for stand differentiation. However, stand differentiation may be due less to competition and more to species affinity for a particular soil. In a study linking soil moisture and nutrient content in planted stands on former agriculture fields, Cogliastro et al. (1997) demonstrated that different species achieve maximal growth under different conditions. Some species, such as red oak, achieve their best growth in nutrient poor soils. This indicates that species' presence on such soils may be caused less by their competitive ability and more by their preference for such soils. Either of these mechanisms, competition or species affinity for soil, would result in tree succession tracking the changes in the soils. Alternately, succession may be not be driven by soil properties, but by other stand dynamics such as competition for light (Bush and Van Auken 1986), life histories, and colonization abilities (Tilman 1985, Huston and Smith 1987). Some authors combine these variables, for example theorizing that succession is a tradeoff between competitive ability and growth rate (Gleeson and Tilman, 1990).

This nutrient cycle varies according to biomass turnover (litterfall) and leaching losses from plants. The high turnover of relatively nutrient-rich biomass in pioneer, shrub, and seral hardwood stages can exceed the turnover in late successional stages, so that in mesoseres the biogeochemical cycle can peak in an early seral stage (Figure 2-16).

According to Bauhus, J. (2003) biogeochemical cycling in the mature stage (tree forest floor - tree) is probably largely confined by direct nutrient tends to slow down at the mature stage because of changes in the organic and inorganic chemistry of the litter, nutrient turnover is probably reduced. The apparent adaptation of accumulation of nutrients by promoting direct nutrient cycling and inhibiting mineralization probably helps the mature forest to perpetuate itself and to compete with other species even id it does reduce rates of nutrient turnover and productivity.

Internal nutrient cycling is an important conservation mechanism exhibited by late secondary vegetation. Not enough is known yet about the variation of internal cycling during different stages of succession. However, results indicate that nutrient accumulation within the ecosystem as succession proceeds, there is a trend toward a greater degree of internal cycling. Probably because by removing a greater proportion 
of the nutrients from its old foliage prior to abscission, a plant can store nutrients more efficiently, thereby rendering them less available to competitors.

\section{Variability and consequence of land use history}

Although the study area is relatively homogeneous in topography and parent material, the physical and chemical properties of mature forest soils did vary (Lawrence, 2002; Tiessen et al., 1999). Some of this variation results from interactions between vegetation and soils through geologic time. It may also be caused by differences in the intensity of historic land use during the past century. It could also result from ancient Mayan activity. An important part of the variation, especially in soil organic matter, is most likely a result of the regional precipitation gradient. In particular, the southern site tended to have a higher organic matter content, as expected if litter inputs were higher due to greater precipitation (Lawrence, 2002).

Soil $\mathrm{pH}$ was generally quite high across the region (7.4-7.7) as a result of parent material rich in calcium carbonate.

Overall fertility may be lower in young secondary forest given lower levels of soluble sulphur. This lower fertility could reflect the longer history of agriculture there.

Unlike the other indices of fertility noted above, K levels were significantly higher in young forest which may indicate translocation functions of plants when $\mathrm{K}$ becomes limiting factor. This result is consistent with more rapid turnover of organic matter or greater amounts of material cycling through the forest floor litter layer.

In this case, $\mathrm{K}$ could accumulate in the mineral soil due to greater leaching from litter on the forest floor. This is not incongruent with limitations on productivity due to soil fertility. Rapid nutrient cycling through the litter can be an important mechanism for conserving and efficiently using essential nutrients that have been depleted in the mineral soil (Lawrence, 2002, Chapin, 1980, Jordan and Herrera, 1981). 


\section{Effects of forest age on biomass and nutrient cycling}

Forest floor biomass increased with age. Higher age should enhance decomposition, leading to lower forest-floor biomass if litter production were to remain constant.

Differences in total annual precipitation and soil characteristics may contribute to variation in structure and function of forest. To isolate the regional influence on forest processes from the effects of forest age and cultivation history all plots were located in the same ecosystem.

Forest age had a great impact on ecosystem properties and function. Live aboveground biomass increased significantly as a function of forest age (Figure 2-6). There was a pronounced difference between mature forests and the oldest secondary forests sampled (12-25 yr). Total annual nitrogen inputs deposited via fine litter in every succession stage of forests.

Both litter production and forest floor biomass increased consistently with age. The difference between young secondary and mature forests was not as dramatic as it was for live biomass. With only $15 \%$ of the aboveground biomass, the youngest forests produced almost $70 \%$ as much fine litter as mature forests. Similar results were reported by Lawrence (2002), and Ewel (1976) in Mexico and Guatemala.

The pattern of high productivity in young forests matches that observed in succession forests of the temperate zone as well (Odum, 1969). The increase in forest floor biomass was more rapid than that expected due to the increase in litter production, suggesting that decomposition slows with forest age. Experimental studies confirmed that decomposition is slower in older forests. Lower decomposition rates seemed to occur in response to lower litter quality rather than to changes in microclimate (Xuluc-Tolosa et al., in press).

Older forests produced greater amounts of litter (Figure 2-20), while cycling the same amount of $\mathrm{N}$ as younger forests (Figures 2-21 and 2-22), resulting in a decline in litter $\mathrm{K}$ concentration with age. In contrast, the pool of $\mathrm{N}$ cycled through litter increased in step with increasing litter production in older forests. Litter $\mathrm{N}$ concentration did not 
increase significantly, although there was a tendency for slightly higher concentrations in older forests.

Likewise, we attributed the increase in forest floor mass with age to added inputs and slowed decomposition. Data on $\mathrm{K}$ concentrations support this interpretation: $\mathrm{K}$ concentration was lowest in mature forest soils, where turnover rates of organic matter are expected to be slowest due to a decline in litter quality.

Tree pruning is a common management practice in agroforestry for mulching and reducing competition between the annual and perennial crop. The below-ground effects of pruning, however, are poorly understood (Peter and Lehma, 2000).

Taken together, these data suggest that $\mathrm{N}$ use efficiency declined, if it changed at all, as a function of forest age. When water is broadly limiting (as in the above analysis of nutrient dynamics as a function of forest age, regardless of regional precipitation gradients), productivity seems to be limited by $\mathrm{N}$ availability. More $\mathrm{N}$ cycling through the system was correlated with higher litter production. All forests cycled similar amounts of $\mathrm{P}$ regardless of age. This level may represent the maximum $\mathrm{P}$ accessible given the soil-climate regime. 


\subsection{CONCLUSIONS}

The long history of use of these ecosystems together with the environmental conditions (karst, peninsularity, lack of tophography and recent geology) has influenced the actual vegetation of the area (Iturbe-Gonzalez et al., 2002, Challenger, 1998). However, as our results indicate, pressures such as Sisal cultivation have had a strong effect on the diversity and composition of the succession forest. Our results strongly suggest that the SS3 plots sampled are the last representative of the low stature deciduous forest (Dzibilchaltun and the Sacahba Reserve sites), although also reduced in species richness, in comparison with other dry forests in other regions, indicates that the younger succession stages would probably not obtain a similar composition to that of the older vegetation. The recovery of the low deciduous forest of northern Yucatan will be difficult if the remnants of old forest, which could function as seed sources, are not preserved.

Accompanying the changes in vegetation are some major changes in soil conditions over the 30 years of succession. In the early stages the soils are merely disorganized accumulations of debris. Following invasion there is a progressive modification of many of the soil's properties. In northern Yucatan, the rate of organic accumulation increases as the forest stage develops.

Accumulation of organic carbon in the mineral soil layer increased during the chronosequence. Concentrations of $\mathrm{C}$ and $\mathrm{N}$ in red and black mineral soils were significant different with respect to age. Without exception, mineral soil $\mathrm{C}$ and $\mathrm{N}$ concentrations increased with increasing age class.

Our results showed that $\mathrm{Mg}$ was affected by land use. $\mathrm{K}$ content was very low and was highly influenced by forest age. The highest $\mathrm{K}$ content was found in SS2. This results in $\mathrm{K}$ trends shows that internal nutrient cycling might be an important conservation mechanism exhibited by late secondary vegetation. Not enough is known yet about the variation of internal cycling during different stages of succession. However, results indicate that nutrient accumulation within the ecosystem as succession proceeds, there is a trend toward a greater degree of internal cycling. 
Probably because by removing a greater proportion of the nutrients from its old foliage prior to abscission, a plant can store nutrients more efficiently, thereby rendering them less available to competitors. One might expect, therefore, that internal cycling will become more efficient as succession proceeds. Further studies are necessary to test the validity of this hypothesis.

There are some indications that soil properties and limiting factors are influenced by soil type, land use and forest age. However, an experiment controlling for moisture within plots, soil type, stand age, and site history would be appropriate to confirm which factors influence which soil properties and how.

Forest ages do appear to influence mineralization of nitrogen, and carbon through differing inputs of leaf litter. While there may be other factors in the species' influences on soil processes, differences in leaf litter correlates well with changes in soil processes under increasing forest age.

The low levels of exchangeable $\mathrm{K}$ may be a limiting factor in these calcareous soils (Aguila, 2007). K could still be limiting for productivity, but we cannot determine the limitation by simply comparing $\mathrm{K}$ return with litter production, as a function of forest age.

Time alone (as a forest ages) will not allow more $\mathrm{K}$ to enter the system, unless fixed biogeochemical constraints are lifted. Although the potential exists for $\mathrm{N}$ uptake through biological fixation, there are no additional pools to tap to alleviate $\mathrm{K}$ limitation.

Increasing production depends, then, on increasing $\mathrm{N}$ availability as the forest and its soils recover from sisal cultivation in Northern Yucatan. When water limitation is alleviated in these secondary forests and soil biological activity is enhanced, certain biogeochemical constraints on $\mathrm{K}$ cycling do seem to be lifted.

Changes in soil $\mathrm{N}$ in regarding to forest age suggest that $\mathrm{N}$ availability may increase during forest regeneration. Although data on the $\mathrm{N}$ and $\mathrm{K}$ content of soils are lacking, 
soil organic matter did increase significantly with age. In the top $15 \mathrm{~cm}$ of soil, organic matter increased from $10-11 \%$ in young secondary forests to $15 \%$ in mature forests. An increase in $\mathrm{N}$ availability associated with an increase in organic matter would allow litter concentrations to remain stable while productivity increases. This increase in soil organic matter probably represents a slowing of mineralization rates in the soil along with a demonstrated increase in litter inputs.

Summarizing, we can affirm that forest age influenced biomass and nutrient content in soils and therefore affect positively ecosystem quality. Forest recovery has important soil nutrient availability implications given the central role in the overall functioning of ecosystems. Secondary forest has the potential to assimilate and restore the carbon and soil nutrients that are lost during Sisal cultivation in Northern Yucatan. 


\subsection{REFERENCES}

Agbenin, J.O. and Tiessen, H. 1994. Phosphorus transformations in a toposequence of Lithosols and Cambisols from semi-arid northeastern Brazil. Geoderma, 62: 342-362.

Abubakar, S. M. 1997. Monitoring land degradation in the semiarid tropics using an inferential approach: the Kabomo basin case study, Nigeria. Land degradation \& development, Vol. 8: 311-323.

Alvarez, R., de Jong, B.H.J., Olmsted, I., 2000. Tropical Mexico's recent land-use change: a region's contribution to the global carbon cycle. Ecol. Appl. 10, 14261441.Composition, structure and management potential of secondary dry tropical vegetation in two abandoned Sisal plantations of Yucatan, Mexico. For. Ecol. Manage. 96, 273-282.

Andrist, I. 2003. Investigation of soils, vegetation and management of homegardens in the Sisal region, Yucatan, Mexico. Minor Field Studies $N^{\circ} 25$. Swedish University of Agricultural Sciences. ISSN: 1402-3237.

Baligar, V. C. and Bennett, O. L. 1986. NPK-fertilizer efficiency - a situation for the tropics. Fertilizer Research 10: 147-164.

Bauhus, J. 2003. Forest Dynamics. Disturbance as the basis for ecosystem management. Lecture notes.

Benjamín, T.J., P.I. Montanez, J.J.M. Jiménez and A.R. Gillespie. 2001. Carbon, water and nutrient flux in Maya homegardens in the Yucatán peninsula of Mexico. Agroforestry Systems 53:103-111.

Brown, S., Lugo, A.E., 1982. The storage and production of organic matter in tropical forests and their role in the global carbon cycle. Biotropica 14, 161-187.

Brown, S., Lugo, A.E., 1984. Biomass of tropical forests: a new estimate based on forest volumes. Science 223, 1290-1293. 
Bautista Zúñiga, F., Jiménez Osornio, J., Navarro Alberto, J., Manu, A., and Lozano, R. 2003. Micro-Relief and soil color as diagnostic properties in carstic leptosols. Terra, Vol. 21, $\mathrm{N}^{\circ}$ 1: 1-11.

Beach, T. 1998. Soil constraints on Northwest Yucatan, Mexico: Pedoarchaeology and Maya subsistence at Chunchucmil. Geoarchaeology: An International Journal, Vol. 13, No 8:759-791.

Beck, M. A. and Sanchez, P. A. 1996. Soil phosphorus movement and budget after 13 years of fertilized cultivation in the Amazon basin. Plant and Soil 184: 23-31.

Benjamin, Tamara. 2000. Maya cultural practices in Yucatecan homegardens: an ecophysiological perspective. Thesis submitted to the Faculty of Purdue University in partial fulfillment of the requirements for the degree of Doctor of Philosophy.

Bissuti, I. Hilke, I., and Raessler, M. 2004. Determination of total organic carbon - an overview of current methods. Trends in Analytical Chemistry, Vol. 23, $N^{\circ} 10-11$ : 716-726.

Breuer, L., Huisman, J.A., Keller, T., and Frede, H. G. 2006. Impact of a conversion from cropland to grassland on $\mathrm{C}$ and $\mathrm{N}$ storage and related soil properties: Analysis of a 60-year chronosequence. Geoderma 133: 6-18.

Buehler, S. Oberson, A., Rao, I.M., Friesen, D.K., and Frossard, E. 2002. Sequential extraction of a 33P-labeled Oxisol under contrasting agricultural systems. Soil Sci.Soc. Am. J. 66: 868-877.

Bünemann, E.K., Steinebrunner, F., Smithson, P.C., Frossard, E., and Oberson, A. 2004. Phosphorus dynamics in a highly weathered soil as revealed by isotopic labeling techniques. Soil Sci. Soc. Am. J. 68: 1645-1655.

Caballero, R., Gandarilla, J., Pérez, K., Pacheco, O., and Sánchez, M. 2001. Efecto del humus de lombriz combinado con la fertilización mineral en el cultivo del ají Chay. Centro Agrícola, N 4, oct.- dec.: 15-17. 
Cairo, P. and Fundora, O.1994. Clasificación de los suelos (Chapter 15). In: Edafología. Editorial Pueblo y Educación. Segunda edición ampliada y corregida. La Habana. ISBN: 959-13-0209-6. p: 348-420.

Campo, J., Maass, J. M., Jaramillo, V. J., and Martínez Yrízar, A. 2000. Calcium, potassium, and magnesium cycling in a Mexican tropical dry forest ecosystem. Biogeochemistry 49: 21-36.

Caravaca, F., Lax, A., and Albaladejo, J. 1999. Organic matter, nutrient contents and cation Exchange capacity in fine fractions from semiarid calcareous soils. Geoderma 93: 161-176.

Cardoso, I. M. 2002. Phosphorus in agroforestry systems: a contribution to sustainable agriculture in the Zona do Mata of Minas Gerais, Brazil. PhD thesis, Wageningen University. ISBN: 90-5808-746-8.

Carreira, J. A., Vinegla, B., and Lajtha, B. 2006. Secondary CaCO3 and precipitation of P-Ca compounds control the retention of soil P in arid ecosystems. Journal of Arid Environments 64: 460-473.

Ceccon, E., I. Olmsted, C. Vazques-Yanes, and J. Campo. 2002. Vegetation and soil properties in two tropical dry forests of differing regeneration status in Yucatán. Agrociencia 36:245-254.

Chiapy, C. and Gama, L. 2004. Modificaciones y fragmentación de los geocomplejos tropicales de Península de Yucatán. Universidad y Ciencia, Número Especial I: 17-25. At: www.ujat.mx/publicaciones/uciencia

Cross, A.F. And Schlesinger, W. H. 2001. Biological and geochemical controls on phosphorus fractions in semiarid soils. Biogeochemistry 52: 155-172.

Damodar Reddy, D., Subba Rao, A., and Takkar, P. N. 1999. Effects of repeated manure and fertilizer phosphorus additions on soil phosphorus dynamics under soybean-wheat rotation. Biol. Fertil. Soils 28:150-155. 
de Vries, A.J. 2000. The semiarid environment of Curaçao: a geochemical soil survey.Netherlands Journal of Geosciences 79 (4): 479-494.

Drury, C. F., Zhang, T. Q., and Kay, B. D. 2003. The non-limiting and least limiting water ranges for soil nitrogen mineralization. Soil. Sci. Soc. Am. J. 67: 1388-1404.

Duch, J. 1988. Los regimenes climáticos (Chapter IV). In: La conformación territorial del Estado de Yucatán. Los componentes del medio físico. p: 107-230.

Echenique, J. J. 2005. Natural $\delta$ 13C signals and soil organic carbon turnover in calcareous soil of Yucatan, Mexico. MSc. Thesis. University of Goettingen. 53p.

FAO. 1989. FAO-Unesco soil map of the world, revised legend. World resources. Report 60.

FAO, Rome. FAO. 2000. Problem soils database. Available online at: http://www.fao.org/ag/agl/agll/prosoil/calc.htm.

Fierer, N. and Schimel, J. P. 2002. Effects of drying-rewetting frequency on soil carbon and nitrogen transformations. Soil Biology \& Biochemistry 34: 777-787.

Fisher, F. M. and Whitford, W. G. 1995. Field simulation of wet and dry years in the Chihuahuan desert: soil moisture, $\mathrm{N}$ mineralization and ion-exchange resin bags. Biol. Fertil. Soils 20: 137-146.

Fundora Herrera, C.O. 1979. Untersuchungen ünter des Kalium-Haushalt wichtiger Böden Kubas. Dissertation for the degree of Doctor in Agricultural Sciences. Leipzig University. $132 \mathrm{pp}$.

Gonzalez-Iturbe, J.A., I. Olmsted, and F. Tun-Dzul. 2002. Tropical dry forest recovery after long term Sisal (Sisal, Agave fourcroydes Lem.) plantation in northern Yucatán, Mexico. Forest Ecology and Management. 167:67-82.Changes in the landscapes of Latin America 
Giardina, C. P., Sanford, R. L. Jr., Dǿckersmith, I. C. 2000. Changes in soil phosphorus and nitrogen during slash-and-burn clearing of a dry tropical forest. Soil Sci. Soc. Am. J. 64: 399-405.

Glaser, B., Lehmann, J., Führböter, M., Solomon, D., Zech, W. 2001. Carbon and nitrogen mineralization in cultivated and natural savanna soils of Northern Tanzania. Biol. Fertil. Soils 33: 301-309.

Greer, K. J., Sulewski, C., and Hangs, R. 2003. Applying PRSTM technology for nutrient management. Western Nutrient Management Conference. Vol. 5:170-175.

Günther, D. and Lehmann, J. 2000. Soil phosphorus properties and management for perennial crops in the central Amazon. German-Brazilian Workshop on Neotropical Ecosystems-Achievements and prospects of cooperative research (Proceedings) CDROM (Code 0339991) References 137.

Guo, F., Yost, R.S., Hue, N.V., Evensen, C.I., and Silva, J.A. 2000. Changes in phosphorus fractions in soils under intensive plant growth. Soil Sci. Am. J. 64: 16811689.

Gonzalez-Iturbe, J., Olmsted, I, \& Fernando Tun-Dzul, 2002. Tropical Dry Forest recovery alter long Sisal (sisal, Agave Fourcroydes Lem.) plantation in Northern Yucatan, Mexico.

Helfrich, M., Ludwig, B., Buurman, P., and Flessa, H. 2006. Effect of land use on the composition of soil organic matter in density and aggregate fractions as revealed by solid-state 13C NMR spectroscopy. Geoderma: In press. 11p. Available online at: http://www.sciencedirect.com

Hinsinger, P. 2001. Bioavailability of soil inorganic P in the rhizosphere as affected by root induced chemical changes: a review. Plant and Soil, 237: 173-195. 
Houghton, R.A., Lelkowitz, D.S. and Skole, D.L. 1991. Changes in the landscape of Latin America between 1850 and 1985. Progressive loss of forest. For. Ecol. Manage., 38: $143-172$.

Imas, P. 2000. Integrated nutrient management for sustaining crop yields in calcareous soils. Presented at GAU-PRII-IPI National Symposium on: Balanced nutrition of groundnut and other field crops grown in calcareous soils of India. Available online at: http://www.ipichina.org/presentn/inmfscy.html

Iyamuremye, F., Dick, R. P., and Baham, J. 1996. Organic amendments and phosphorus dynamics: II. Distribution of soil phosphorus fractions. Soil Sci. 161 (7): 436-443.

Jahns, T. 2005. Animal Manure as fertlizers. Small farm series. Available online at: http://www.uaf.edu/ces/publications/freepubs/LPM-00340.pdf

Jobbágy, E. G. and Jackson, R. B. 2001. The distribution of soil nutrients with depth: Global patterns and the imprint of plants. Biogeochemistry 53: 51-77.

John, B. M. 2003. Carbon turnover in aggregated soils determined by natural 13C abundance. $\mathrm{PhD}$ Thesis. University of Goettingen. 157p. Available online at: http://webdoc.sub.gwdg.de/diss/2003/john/john.pdf

Johnson, J. and Eckert, D. 1995. Best management practices: land application of animal manure. AGF-208-95. Available online at: http://ohioline.osu.edu/agffact/0208.html

Juo, A. S. R. and Manu, A. 1996. Chemical dynamics in slash-and-burn agriculture. Agriculture, Ecosystems and Environment 58: 49-60.

Kay, B.D., Tollenaar, M., Drury, C. F., Ying, J., Chromiak, C., and Zhang, T. 1999. Increasing nitrogen use efficiency in corn production systems: quantifying effects of References 138. 
Kishchuk, B., Mynard, D., and Curran, D. 1999. Calcareous soils. Technology transfer note. Forestry Research Applications. $\mathrm{N}^{\circ}$ 15. Available online at: http://www.dsppsd.pwgsc.gc.ca/Collection/Fo29-47-15-1999E.pdf

Kleinhenz, V., Schnitzler, W. H., and Midmore, D. J. 1997. Seasonal effects of soils moisture on soil $\mathrm{N}$ availability, crop $\mathrm{N}$ status, and yield of vegetables in a tropical, ricebased lowland. In: Der Tropenlandwirt, Beiträge zur tropischen Landwirtschaft und veterinärmedizin, 98. jahrgang, April 97, S. 25-42. Online available at: http://trophort.com/pdf/Pub/Seasonal_effects_of_soil_moisture.pdf

Knopp, K. L. and Guillard, K. 2002. Relationship of turfgrass growth and quality to soil nitrate desorbed from anion exchange membranes. Crop Sci. 42: 1232-1240.

Koide, R.T. and Mooney, H.A.1987. Revegetation of serpentine substrates: response to phosphate application. Environmental Management, Vol. 11, № 4, pp: 563-567.

Kovar, J. L. and Claassen, N. 2005. Soil-root interactions and phosphorus nutrition of plants. Phosphorus: Agriculture and the environment, Agronomy monograph $\mathrm{N}^{\circ} 46$ : 379-414.

Lawrence, D., D. R. Peart, and M. Leighton. 1998. The impact of shifting cultivation on a rainforest landscape in West Kalimantan: spatial and temporal dynamics. Landscape Ecology13: 135-148.

Lajtha, K. and Bloomer, S.H. 1988. Factors affecting phosphate sorption and phosphate retention in a desert ecosystem. Soil Sci. 146: 160-167.

Lajtha, K. and Schlesinger, W.H. 1988. The biochemistry of phosphorus cycling and phosphorus availability along a desert chronosequence. Ecology 69, $\mathrm{N}^{\circ}$ 1: 24-39.

Lawrence, D. and Schlesinger, W. H. 2001. Changes in soil phosphorus during 200 years shifting cultivation. Ecology 82 (10): 2769-2780. 
Lehmann, J., da Silva Cravo, M., Vasconselos de Macedo, J.L., Moreira, A., and Schroth, G. 2001. Phosphorus management for perennial crops in central Amazonian upland soils. Plant and Soil, 237: 309-319.

Levy, E.T. and Schlesinger, W. 1999. A comparison of fractionation methods for forms of phosphorus in soils. Biogeochemistry 47: 25-38.

Leytem A. B. and Mikkelsen, R. L. 2005. The nature of phosphorus in calcareous soils. Better Crops, Vol. 89, $\mathrm{N}^{\circ}$ 2: 11-13.

Mallarino, A. P. and Atia, A.M. 2005. Correlation of a resin membrane soil phosphorus test with corn yield and routine soil tests. Soil Sci. Soc. Am. J. 69: 266272.

Markewitz, D., Davidson, E., Moutinho, P., and Nepstad, D. 2004. Nutrient loss and redistribution after forest clearing on highly weathered soil in Amazonia. Ecological Applications, 14 (4) Supplement. pp: 177-199.

McLaughlin, M. J., Lancaster, P.A., Sale, P. G., Uren, N. C., Peverill, K.I. 1994. Comparison of cation/anion exchange resin methods for multi-element testing of acidic soils. Australian Journal of Soil Research, 32: 229-240.

Misra, A. and Tyler, G. 1999. Influence of soil moisture and soil solution chemistry and concentrations of minerals in the calcicoles Phleum phleoides and Veronica spicata grown on a limestone soils. Annals of Botany 84: 401-410.

Mizrahi, A. P., Ramos, P. J. y Jiménez-Osornio, J. J. 1997. Composition, Structure and Management Potential of Secondary Vegetation in a Dry Tropical Forest. Forest Ecology and Management, 94: 79-88.

Montañez, E. 1998. Producción de hojarasca y aporte de nutrimentos en los huertos familiars de Hocabá, Yucatán - Mexico. Tesis de grado para obtener el grado de maestro en Ciencias en Manejo y Conservación de Recursos Naturales Tropicales, Universidad Autónoma de Yucatán. 
Motavalli, P. P. and Miles, R. J. 2002. Inorganic and organic soil phosphorus fractions after long-term animal manure and fertilization. Better Crops Vol. 86:20-23.

Moya García, X., Caamal, A., Ku Ku, B., Chan Xool, E., Armendáriz, I., Flores, J., Moguel, J., Noh Poot, M., Rosales, M., and Xool Domínguez, J. 2003. La agricultura campesina de los mayas en Yucatán. LEISA. Edición especial: 7-17.

Murphey, J. and Riley, J.P. 1962. A modified single solution method for the determination of phosphate minerals in natural waters. Anal. Chim. Acta 27:31-36.

Neil, C., Piccolo, M.C., Cerri, C. C., Steudler, P. A., Melillo, J. M., and Brito, M. 1997. Net nitrogen mineralization and net nitrification rates in soils following deforestation for pasture across the southwestern Brazilian Amazon Basin landscape. Oecologia: 110: 243-252.

Olmsted, I., Duran, R., 1990. Vegetacio'n de Sian Ka'an. In: Navarro, D., Robinson, J. (Eds.), Diversidad Biolo'gica en Sian Ka'an, Quintana Roo, Mexico. Program for Studies in Tropical Conservation, University of Florida, Gainesville, FL, USA.

Olmsted, I., Gonzalez-Iturbe, J.-A., Duran, G.R., Granados, C.J., Tun, D.F., 1999. Vegetacio'n de la Pen 'nsula de Yucata'n. Chapter 3 in Procesos territoriales de Yucata'n. Universidad Autonoma de Yucatan, Merida, Mexico.

Pampolino, M. F. and Hatano, R. 2000. Comparison between conventional soil tests and the use of resin capsules for measuring $\mathrm{P}, \mathrm{K}$, and $\mathrm{N}$ in two soils under two moisture conditions. Soil. Sci. Plant Nutr. 46 (2): 461-471.

Peña-Claros, M. 2003. Changes in Forest Structure and Species Composition during Secondary Forest Succession in the Bolivian Amazon Biotropica 35 (4), 450-461.

Pierzynski, G.M. 2000. Methods of Phosphorus Analysis. Southern Cooperative Service Bulletin No. 396 June. ISBN: 1-58161-396-2. URL: http://www.soil.nscu.edu/sera17/publications/sera17-2/pm_cover.htm 
Qian, P. and Schoenau, J. J. 2000. Practical applications of ion exchange resins in agricultural and environmental soil research. Can. J. Soil Sci. 82: 9-21.

P. M. Millar. 1999. Effects of Deforestation on Seed Banks in a Tropical Deciduous Forest of Western Mexico. Journal of Tropical Ecology, Vol. 15, No. 2 (Mar., 1999), pp. $179-188$

Read, L. and D. Lawrence. 2003a. Recovery of biomass following shifting cultivation in dry tropical forests of the Yucatan. Ecological Applications 13:85-97.

Read, L. and D. Lawrence. 2003b. Litter nutrient dynamics during succession in dry tropical forests of the Yucatan: Regional and seasonal effects. Ecosystems 6(8):747761.

Rico Gray, V., Chemás, A. and Mandujano, S. 1991. Uses of tropical deciduous forest species by the Yucatecan Maya. Agroforestry systems 14: 149-161.

Rudrappa, L., Purakayastha, T.J., Singh, D., and Bhadraray, S. 2006. Long-term manuring and fertilization effects on soil organic carbon pools in a Tepic Haplustept of semi-arid sub-tropical India. Soil \& Tillage Research 88: 180-192.

Ruttenberg, K. C. 1992. Development of a sequential extraction method for different forms of phosphorus in marine sediments. Limnol. Oceanogr. 37: 1460-1482.

Saggar, S., Hedley, M. J., and White, R. E. 1990. A simplified resin membrane technique for extracting phosphorus from soils. Fertilizer Research 24: 173-180.

Saleque, M.A., Naher, U.A., Islam, A., Pathan, A.B.M.B.U., Hossain, A.T.M.S., and Meisner, C.A. 2004. Inorganic and organic phosphorus fertilizer effects on the phosphorus fractionation in wetland rice soils. Soil Sci. Soc. Am. J. 68: 1635-1644.

Salisbury, S. E. and Christensen, N. W. 2000. Exchange resins measure rotation effect on nutrient availability. Better Crops, Vol. 84, № 3: 14-16. 
Samadi, A. and Gilkes, R.J. 1999. Phosphorus transformations and their relationships with calcareous soil properties of Southern Western Australia. Soil Sci. Soc. AM. J. Vol.63 N4 pp: 809-814.

Saunders, W. M. H. and Williams, E.G. 1955. Obaservations of the determination of total organic phosphorus in soils. Journal of Soil Science, 6: 254-267.

Schlesinger, W. H., Bruijnzeel, L.A., Bush, M. B., Klein, E. M., Mace, K.A., Raikes, J. A., and Whittaker, R. J. 1998. The biochemistry of phosphorus after the first century of soil development on Rakata Island, Krakatau, Indonesia. Biochemistry 40: $37-55$.

Schwinning, S., Sala, O. E., Loik, M. E., Ehleringer, J. R. 2004. Thresholds, memory, and seasonality: understanding pulse dynamics in arid/semiarid ecosystems. Oecologia 141:191-193.

Shang, C., and Tiessen, H. Carbon turnover and Carbon-13 natural abundance in organomineral fractions of a tropical dry forest soil under cultivation. Soil Sci. Soc. Am. J. 64: 2149-2155.

Shang, C., and H. Tiessen. 2003. Soil organic C sequestration and stabilization in karstic soils of Yucatán. Biogeochemistry. 62:177-196.

Sherrod, S. K., Belnap, J., and Miller, M. E. 2003. Comparison of ion-exchange resin counterions in the nutrient measurement of calcareous soils: implications for correlative studies of plant-soil relationships. Communications in Soil Science and Plant Analysis. Vol. 34, N 13 \& 14: 1981-2001.

Sivakumar, M. V. K. and Valentine, C. 1997. Agroecological zones and the assessment of crop production potential. Phil. Trans. R. Soc. Lond. B. 352: 907-916.

Six, J., Elliot, E. T., and Paustian, K. 1999. Aggregate and soil organic matter dynamics under conventional and no-tillage systems. Soil Sci. Soc. Am. J. 63: 13501358. 
Solomon, D. and Lehmann, J. 2000. Loss of phosphorus from soil in semi-arid northern Tanzania as a result of cropping: evidence from sequential extraction and 31P-NMR spectroscopy. European Journal of Soil Science. 51: 699-708.

Soza-Meizoso, C., López, J.G., Pascual, O., and Teruel, E. 2004. Carmita formation as an important consideration for the new Palinspastic reconstruction. AAPG: International Conference, Cancun, Mexico.

Stevenson, F.J. and Cole, M.A. 1999. Cycles of soil. Carbon, nitrogen, phosphorus, sulfur and micronutrients. Second edition. John Wiley \& Sons, Inc. ISBN: 0-47132071-4.

Stewart, J.W.B. and Tiessen, H. 1987. Dynamics of soil organic phosphorus. Biogeochemistry 4: 41-60.

Sui Y.; Thompson, M. L.; Shang, C. 1999. Fractionation of phosphorus in a mollisol amended with biosolids. Soil Sci. Am. J. Vol.63 N4. p: 1174-1180.

Syers, K. J., Sheldrick, W., and Lingard, J. 2002. Nutrient balance changes as an indicator of sustainable agriculture. 17th WCSS, 14-21 August 2002, Thailand. Available online at: http://www.ldd.go.th/Wcss2002/papers/1641.pdf

Tiessen, H., Chacon, P., and Cuevas, E. 1994. Phosphorus and nitrogen status in soils and vegetation along a toposequence of dystrophic rainforests on the upper Rio Negro. Oecologia 99: 145-150.

Tiessen, H. and Moir, J.O. 1993. Characterization of available P by sequential extraction. In: Carter MR (ed) Soil sampling and methods of analysis (special publication of the Canadian Society of Soil Science). Lewis, Boca Raton. Pp: 75-86.

Towsend, A.R, Asner, G.P., Cleveland, C.C., Lefer, M.E., and Bustamante, M.M.C. 2002. Unexpected changes in soils dynamics along pasture chronosequences in the humic tropics. Journal of Geophysical Research. Vol.107. $\mathrm{N}^{\circ}$ D20, 8067, doi: 10.1029/2001JD000650. 
USDA. Soil survey staff. 1992. Key to Soil Taxonomy. SMSS technical monograph $\mathrm{N}^{\circ} 19,5$ th edition, Blacksburg, Virginia, USA, $541 \mathrm{pp}$.

Vestin, J. L. K., Nambu, K., van Hees, P. A. W., Bylund, D., Lundström, U. S. 2006. The influence of alkaline and non-alkaline parent material on soil chemistry. Geoderma: In press. 10p. Available online at: http://www.sciendirect.com

Vitousek, P. M. 1984. Litterfall, nutrient cycling, and nutrient limitation in tropical forests. Ecology, Vol. 65, $\mathrm{N}^{\circ}$ 1: 285-298.

Vogt, R., L. Gay \& C. Bernhofer (1995): The energy balance of a Scots Pine Plantation. Annales Geophysicae, 13 (Suppl. II), 1995: C550.

Weisbach, C., Tiessen, H., and Jimenez-Osornio, J.J. 2002. Soil fertility during shifting cultivation in the tropical karts soils of Yucatan. Agronomie 22: 253-263.

Whalen, J.K. and Chang, C. 2001. Phosphorus accumulation in cultivated soils from longterm annual applications of cattle feedlot manure. J. Environ. Qual. 30: 229-237.

Xuluc-Tolosa, F.J., H.F.M. Vester, N. Ramirez-Marcial, J. Castellanos-Albores, and D. Lawrence. 2003. Leaf litter decomposition of tree species in three successional phases of tropical dry secondary forest. Forest Ecology and Management: 174: 401412.

Yang, J. E., Skogley, E. O. Schaff, B. E., and Kim, J.J. 1998. A simple spectrophotometric determination of nitrate in water, resin, and soil extracts. Soil Sci. Sm. J., Vol. 62, July- August: 1108-1115.

Zavarzin, G. A. 2002. Microbial geochemical calcium cycle. Microbiology, Vol. 71, $\mathrm{N}^{\circ} 1: 1-17$. 
Zech, W., Senesi, N., Guggenberger, G., Kaiser, K., Lehman, J., Miano, T. M., Miltner, A., Schrot, G. 1997. Factors controlling humification and mineralization of soil organic matter in the tropics. Geoderma, 79: 117-161.

Zeng, Q. and Brown, P.H. 2000. Soil potassium mobility and uptake by corn under differential soil moisture regimes. Plant and Soil 221: 121-134. 


\section{CHAPTER 3: GROWTH PATTERNS OF SELECTED TREE SPECIES IN SECONDARY FOREST IN NORTHERN YUCATAN}

\subsection{ABSTRACT}

Forest fallow in large areas of Semiarid Americas plays a vital role in the maintenance of land quality and are also important for the community. The total benefits of ecosystem services provided by forest fallows and the potential for forest production have not been evaluated, largely because forest productivity under secondary land cover has rarely been measured with an eye to marketable products. Sustainable management systems for tropical forests require information on tree growth.

We here explored options for improved landuse management in secondary forest in Northern Yucatan, Mexico. We use tree-ring analysis to predict tree productivity in fallow vegetation at different succession states. Cross dating techniques were used to identify correlation between tree growth and climatic patterns.

Tree species of young secondary forest showed a higher mean annual diameter increment than those from old secondary forest. Tree ring analysis for core-samples showed that the mean ring-widths vary between $0.8 \mathrm{~mm}$ per year in Piscidia and $0.6 \mathrm{~mm}$ per year in Cordia. Tree ring time series from both species were positively correlated with the annual rainfall and total precipitation in the rainy period. These two species showed constant cumulative growth over their entire life span,

Keywords: Tree ring analyses, tree growth, secondary dry forest.

\subsection{INTRODUCTION}

Detailed information on long-term growth rates and ages of tropical dry forest trees is important to obtain a better understanding of the functioning of forests ecosystems. 
Nevertheless, little is known about growth or ages of tropical-dry forest trees, due to a supposed lack of annual tree rings in most tropical tree species and in particular little information exists on the dendrochronology of Yucatec trees (Jimenez et al., 2003).

There are some exploratory works which aim to identify suitable species for dendrochronology and to determine the possibility to explore, as extensively as possible, the potentialities of trees in the dry deciduous forests of northern Yucatan to form distinct and reliably datable growth rings. The existence of clear growth rings in the trees is a key prerequisite for further studies based on interactions between tree growth and the variable environment. A convincing demonstration of the dendrochronogical potential of these species will allow the development of future research programs concerning the ecology of the species and inferences of past environmental changes detected from tree rings.

Annual tree rings in tropical trees have been reported already in 1927 in Indonesia (Brienen, R., 2005) and since that time in more than 20 different countries and in many different tree species throughout the tropics (Worbes, 2002). More than 35 studies reported the occurrence of tree rings and many of them have proven that rings were formed on an annual basis. Notwithstanding, many authors have claimed that tropical trees do not produce annual tree rings (Lieberman et al. 1985a; Whitmore 1998) or emphasize the problems regarding the use of tropical tree rings (Laurence et al. 2004).

Information on tree ages and growth rates is crucial to understand the dynamics of tree populations (Enright \& Hartshorn 1981) and to develop sustainable management systems for tropical timber species (Stahle et al. 1999; Worbes et al. 2003). Formation of annual tree rings in tropical tree species can be caused by annual floodings (Schongart et al. 2002; Dezzeo et al. 2003, Brienen, R., 2005), or seasonal variation in rainfall (Worbes 1999; Borchert 1999), and possibly by unidentified internal rhythms (Alvim et al. 1978). In most non-flooded forest areas the formation of tree rings is probably induced by the occurrence of an annual dry season of several months (Worbes 1999; Brienen, R., 2005). Due to a water deficit, tree species often show a reduced diameter growth or cambial dormancy during the dry season, resulting in the formation of a distinct growth boundary 
(Worbes 1999). Many ring forming species are deciduous or change all their leaves during the dry period (Worbes 1999; Borchert 1999). Within the tropics several studies already showed significant correlations between tree ring widths chronologies with precipitation in different time periods (Worbes, 1999). The connection between the formation of annual tree rings and seasonal precipitation was well illustrated by Brienen, R. (2005). He found that trees of one species might form clear and annual rings under (seasonal) monsoon climates, while forming less distinct or irregular rings under almost everwet conditions. Worbes (1999) suggested that a dry period of at least 2 months with less than $50 \mathrm{~mm}$ of rain would be required to expect annual rings in tropical tree species, but recently annual rings have been proven for tree species in everwet climate (all months $>100 \mathrm{~mm}$; Fichtler et al. 2003). Even small annual variation in rainfall occurring under everwet conditions may trigger ring formation.

Although many studies verified the strong relationship between the phenological development and the water status of the trees in tropical dry forests, strongly affected by seasonal drought, light also seems to be a limiting factor of tree growth in tropical and subtropical mature forests. Under closed canopy generally only $1-2 \%$ of the light penetrates to the forest floor (Brienen, R., 2005). Juvenile trees growing at the forest floor may be released by such canopy openings and expose higher growth rates (Canham 1985). These differences between species in light requirements have often been put forward to explain the high species diversity of tropical and subtropical forests (Brienen, R., 2005).

According to the use and tolerant to light, two species groups related to life strategies can be clearly distinguished: pioneer trees ('short-lived pioneers', Swaine \& Whitmore 1988) and non-pioneer trees(classified in various ways, cf. 'shade-tolerants', 'primary species', 'climax species'). Pioneer species have high light requirements for germination and growth, and are generally short-lived. Non-pioneer species do not need high light for germination and are able to survive prolonged periods in the dark forest understorey, growing at low rates. 
The differences between those two major groups are well known, but the majority of tropical rainforest tree species belong to the non-pioneer group (Swaine \& Whitmore 1988). No much research in semiarid forest has been carried out in this respect.

There is an ongoing debate to what extent the coexistence of the many non-pioneers can be explained by differences in light requirements. Many studies have tackled this problem, often proposing different sub-divisions of the non-pioneer group, based on degree of light requirement or shade tolerance. So far, these classifications have mainly been based on seedling performance (Poorter 1998) or sapling performance (Poorter \& Werger 1999), on the occurrence of saplings or larger trees under different natural light conditions (Clark \& Clark 1992; Poorter \& Arets 2003), or on maximum diameter growth of trees (Clark \& Clark 1999).

Classifications resulting from such studies are not consistent, and differences between species are less clear for large trees, which seem to share the same characteristics (Lieberman et al. 1995).

One of the most important criteria that has been put forward in these classifications is whether a species requires a gap for successful regeneration (Clark \& Clark 1992).

Commonly, it is suggested that all canopy species depend on gaps for successful regeneration (Hartshorn 1978), but that they may vary in the size and frequency of gaps needed for successful regeneration. Canopy accession of most non-pioneer trees is a process that may take more than 50 years (Clark \& Clark 2001). This is long compared to the periods covered by most studies on tree growth in permanent sample plots, which typically lasted for $<20$ y (Condit 1995). Clearly, these time periods are to short to follow individual trees all the way from seedling until they reach the canopy and empirical data describing the growth trajectory towards the canopy do no exist for tropical forest trees (Clark \& Clark 2001). Hence, a direct assessment of the degree of gapdependence of individual trees over their entire life has not been possible so far. Tree ring analysis may assist to fill this knowledge gap as it allows for the reconstruction of historical growth 
patterns over the entire life of trees. Such long-term growth data may reveal differences between species in temporal patterns of canopy accession, which are an indication of differences in life history. For instance, the length of periods of slow growth observed in tree ring series may indicate tolerance to shade (Landis, 1999) and the number of instances of sudden growth increases may indicate the number of disturbances that species require to reach the canopy (Lorimer et al. 1988). Tree ring analysis has greatly improved the understanding of tree ecology and forest dynamics in temperate trees, (Canham, 1985), and a similar contribution can also be expected for tropical forests.

Aim of this study was to study the occurrence of annual tree rings in Yucatec species in the Northern Yucatan Peninsula, and to use these rings to reconstruct historical growth patterns and determine ages. These data were also used to evaluate the potential of two timber species for obtaining a sustainable timber harvest.

Forest growth pattern is an important criterion for evaluating of site quality, growth performance of tree species and developing silvicultural systems.

\section{Objectives:}

1) To investigate diameter growth and long term growth trend of two selected tree species.

2) To estimate potential timber production of one selected tree species.

3) To investigate the relation between precipitation, temperature and growth variations.

\section{Research questions:}

1 What are the growth rates and potential for timber production in Northern Yucatan?

2 What is the effect of seasonality in the growth regime of selected tree species? 
3 What is the growth pattern of 2 selected tree species; Piscidia piscipula, Cordia dodecandra (Timber) in secondary forest?

\section{Hypotheses:}

H1: This secondary forest has the potential to produce medium amount of timber

( $>1 \mathrm{~m}^{3} / \mathrm{ha} / \mathrm{yr}$ ) or medium amount of firewood $\left(>2 \mathrm{~m}^{3} / \mathrm{ha} / \mathrm{yr}\right)$.

$\mathrm{H} 2$ : Tree rings in these secondary forests are of annual nature.

H3: Diameter and age of trees correlate significantly with each other.

H4: High temperature and precipitation increases radial growth in tree species.

\subsection{MATERIAL AND METHODS}

\section{Study Area}

This study was carried out in six localities in a semiarid ecosystem of Northern Yucatan. The vegetation of the area has been study by Gonzalez-Iturbe et al. (2001) as in transition between dry subtropical forest and arid tropical forest according to Holdrige (1967), classified as a low deciduous forest.

The average annual precipitation is about $760 \mathrm{~mm}$ and the average temperature is $26{ }^{\circ} \mathrm{C}$. The climate in the region is seasonal; the rainy season contributes $75 \%$ of the total precipitation (Gonzalez-Iturbe et al. 2001).

Fieldwork activities were concentrated at the northern sector of the Mexican state of Yucatán. Yucatan State is a wedge-shaped area in the northern sector of the Yucatan Peninsula, limited to the east and SE by Quintana Roo State and to the SW by Campeche State. Most of this territory is a karst plain developed on Pleistocene limestones. No permanent rivers cross this region and surface water accumulates in the "cenotes". These are circular holes formed by cave collapse which reveals the underground drainage 
system. Thus, during the rainy season, water infiltrates into the karst which has a well developed underground drainage system connecting the cenotes.

The closeness of Yucatan to the sea and the lack of mountains are determining factors for the climate. The climate can be classified as semi-humid warm tropical with summer rains in most of the peninsula (Koppen modified by García, 1973). Rains are concentrated in summer and a marked drought prevails from November to April. At the beginning of the rainy season (May - June) rains are of low intensity and of long duration. They are modulated by the trade winds and by the northwards displacement of the Intertropical Convergence Zone.

During the second phase, September-October, the rains occur as strong showers with sporadic electric storms of short duration. In the dry season (November - April), the "nortes" appear, contributing approximately $30 \%$ of the annual/rain. The arrival of these cold air masses in the winter results in frontal rainfall which is light and intermittent. Cyclones occur every 8 or 9 years and the return period of the cyclones characterized as dangerous is $8-15$ years.

\section{Description of Cordia dodecandra}

The native multi-purpose tree C. dodecandra A.DC. (Siricote) from the family Boraginaceae was reported to establish and grow well during the first years (Reuter, 2005). C. dodecandra produces timber with higher export market value than mahogany (S. macrophylla). Fruits of C. dodecandra are sold for the traditional dessert. Leaves serve as substitute for sandpaper, and the bark of trees is used for medicinal purposes. Due to the roughness of its leaves, goats do not harm the seedlings, and soon benefit from shade and shelter provided by the tree (Vlek et al., 2004). Synonyms are Cordia angiocarpa A.Rich., Cordia heccaidecandra Loesener, Cordia dodecandria S. and M. and Plethostephia angiocarpa (A.Rich.) Miers.. Common names for C. dodecandra include Ciricote or Siricote (on the Yucatan Peninsula), Trompillo (Veracruz), Cupapé 
(Chiapas), Palo de Asta (Guatemala) and the Mayan name K'opté. The name K'opté contains the Mayan word tea meaning very hard wood (Reuter, 2005).

In Northern Yuacatan, C. dodecandra is found in Mayan homegardens, where it is part of the upper canopy stratum. C. dodecandra is listed as one of the species in danger of extinction (Flores and Gerez,1994). It was registered in Mexico in the Southern States of Veracruz, Chiapas, Campeche, Quintana Roo and Yucatan, as well as in Belize and Eastern Guatemala. C. dodecandra grows up to a height of $30 \mathrm{~m}$, with diameters of up to $70 \mathrm{~cm}$ and a straight bole. The ascending branches form a dense crown with a rounded or pyramidal shape (Pennington and Sarukhan, 1998). The tree has a strong taproot (Jankiewicz et al., 1986). The bark is ash-gray, 10 to $20 \mathrm{~mm}$ thick. It is used as a dying agent for sisal fibers, and for the preparation of a remedy against coughs. The softwood is light yellow, while the heartwood is greenish brown to dark brown with large vessels, short and conspicuous rays, vasicentric parenchyma, aliforme, and some paratracheal bands. The decorative pattern of the heartwood, with blackish brown streaks on olivebrown background, and its high durability made it a highly appreciated timber for highquality veneer, as well as decorative furniture and ornamental pillars. It has been widely used for construction, for doors, windows, beams and railroad ties.

Small parts of heartwood were used for handicraft and small wooden sculptures. The high price of the timber resulted in over-exploitation for the national and international market during the past decades, and led to regulations restricting the harvesting of this species. At present, special permits are required before harvesting Siricote, in order to prevent extinction of this valuable timber species (Reuter, 2005).

C. dodecandra flowers and bears fruits in the dry season. Flowers have a green-yellow calyx of 1.5 to $2 \mathrm{~cm}$ length and a 4 to $6 \mathrm{~cm}$ long corolla of intense orange color, with 12 to 13 stamens of varying length, the longest as long as the corolla (Pennington and Sarukhan, 1998; Reuter 2005). Potential pollinators probably include insects similar to those pollinating Cordia alliodora: in humid as well a in dry areas of Costa Rica, bees, wasps, butterflies, beetles and flies (of the orders of Coleoptera, Diptera, Hymenoptera 
and Lepidoptera) visit its flowers (Boshier and Lamb, 1997). C. dodecandra is used for apiculture (Villanueva, 1989). Fruits of $C$. dodecandra are conic drupes of up to $5 \mathrm{~cm}$ diameter. They are yellowish-green, have a thick skin and a highly lignified stone with one to two seeds. Leaves are dark green on the upper side and light green on the reverse, oval to elliptic, with a surface of 5.5 by 4 to 12 by $9 \mathrm{~cm}$, and petioles of 10.8 to $3 \mathrm{~cm}$. Their surface is hairy and rough (Pennington and Sarukhan, 1998). Therefore, Mayan carpenters use them to soften timber, and by Mayan farmers they are traditionally used to clean dishes, especially bowls made out of the fruits of Crescentia cujete. In some villages this is still a common practice (Rojas Lara, 2004). Leaves may be stored dry and wetted again before use (Reuter, 2005). The tree bears fruits from the age of 3 to 4 years on, and produces timber after 25 to 30 years (Montañez, 2002). The fruit yield from 5- to 8 -year-old trees is 10 to $15 \mathrm{~kg} /$ tree (Jankiewicz et al., 1986).

\section{Description of Piscidia piscipula}

Piscidia piscipula also known as the Florida Fish-poison tree is a member of the pea family (family Fabaceae) which includes trees, shrubs, herbs, and vines with compound leaves and flowers in clusters. The species flowers, leaves and fruits have been described by eNature (C) (2001) as follows: Flowers: 3 distinct kinds. The most common, the "pealike flower," has a broad upper petal (banner or standard), 2 lateral petals (wings), and 2 bottom petals (keel) joined and shaped like the prow of a boat; usually has 9 stamens joined and 1 free, surrounding the ovary and hidden inside the keel. The two other kinds of flowers are those of Acacias, radially symmetrical and with conspicuous stamens, and those of Sennas, bilaterally symmetrical, but without a distinct banner and keel. Leaves: pinnately or palmately compound; or sometimes simple by evolutionary loss of leaflets. Fruit: 1-chambered pod that usually opens along one or two seams. This enormous family includes such products as peas, beans, soybeans, peanuts, and lentils. Alfalfa and Clover provide forage for domestic livestock, but many other species are poisonous range weeds. Exotic hardwoods and gum arabic are provided by tropical trees belonging to this family, and numerous members are cultivated as handsome ornamentals. 


\subsection{METHODOLOGY}

We extracted dendro samples from trees within the 18 sites which were previously described in chapter 2 . These secondary forest sites range in age from 3 to $50 \mathrm{yr}$ since abandonment. We tried to collect as much cores as possible from trees with $\mathrm{dbh}>10 \mathrm{~cm}$ located in different sucessional stages. En each selected tree, two wood samples were taken at breast height with an increment corer (Ø $5 \mathrm{~mm}$ ) (see Figure 3-1).

We selected two timber species that all produce clear and annual rings in our study area. For tree ring analysis following tree species were selected

\section{Cordia dodecandra (Timber) \\ Piscidia piscipula (Timber, firewood)}

The selection species criteria were:

- shows annual ring differentiation

- is suitable for sustained timber production

- is suitable for sustained fuel wood production

- is abundant and well distributed along selected sites

- is a native from this region and understanding of its ecology may contribute with biodiversity conservation initiatives

- is well accepted by local people toward continuous production

The selected two species are exploited for the timber, but vary in market value and available volume. 
Table 3-1. Dendro-cores collected at different succession stage

\begin{tabular}{lcccc}
\hline \multirow{2}{*}{ Species } & \multicolumn{3}{c}{ Succession stage* } & Total \\
& SS1 & SS2 & SS3 & \\
\hline Cordia dodecandra & 1 & 1 & 6 & 8 \\
Piscidia piscipula & 8 & 8 & 30 & 46 \\
\hline Total & $\mathbf{9}$ & $\mathbf{9}$ & $\mathbf{3 6}$ & $\mathbf{5 4}$ \\
\hline${ }^{*} \operatorname{SS1}(<10 \mathrm{yr}), \mathrm{SS} 2(10-20 \mathrm{yr}), \operatorname{SS} 3(>20 \mathrm{yr})$ & & & &
\end{tabular}

* SS1 $(<10$ yr), SS2 (10 - $20 \mathrm{yr}), \mathrm{SS} 3(>20 \mathrm{yr})$

Approximately 54 suitable sample trees were cored at the height of $1.3 \mathrm{~m}$ with increment borers. Two cores from each specie were collected, when possible, in one plot at each study site. Samples were chose randomly from a set of existing trees within each plot. The holes caused by the increment corer in the tree were refilled with a plug.

If less than two sample-trees (of particular specie) are found in a site (e.g. non presence of pioneer species in a mature secondary forest) smaller sample size were consider. Total height, commercial height, crown height, dhb, and dominance (1-5) ${ }^{1}$, diameter of branches and their length was recorded in each of these 86 trees.

In order to calculate timber volumes, we first determined for each species the relation between diameter at breast height $(\mathrm{DBH}, \mathrm{cm})$ and commercial heights $(\mathrm{H}$, height to the lowest branch, in $\mathrm{m}$ ) using a logarithmic function.

We used a set of stem discs for estimating dating accuracy and to learn anatomical differences between annual and nonannual growth zones. These stem discs were collected from fallen trees.

\footnotetext{
${ }^{1}$ 1: Tolerant and died trees, 2: Suppressed tree, 3: Intermediate dominance 4:Co-dominant, 5: Dominant
} 


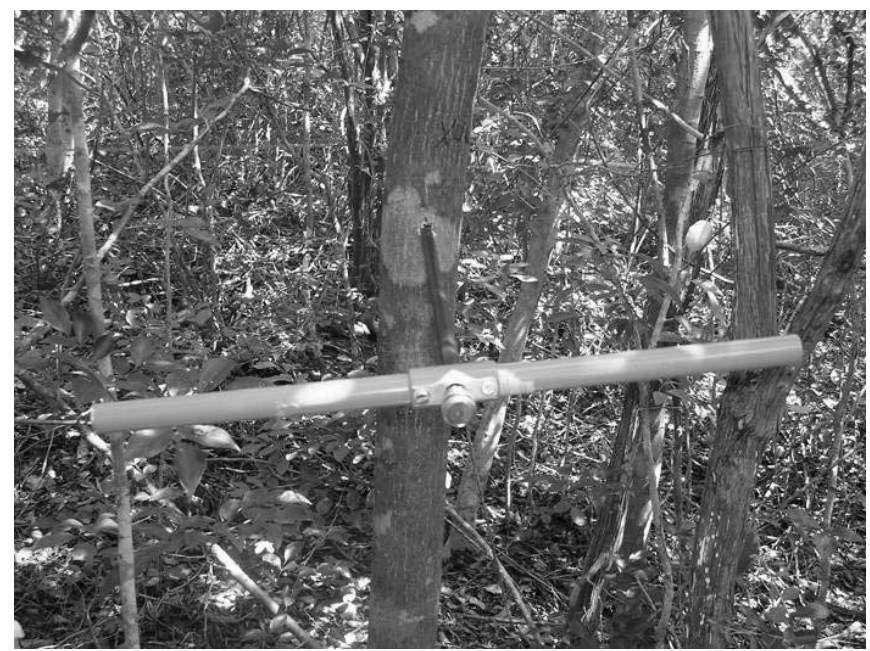

Figure 3-1. $30 \mathrm{~cm}$-increment borer

utilized to collect core sample from selected trees.

Selected species were identified in each plot and samples for tree ring analysis were taken with an increment borer in direction to the central part of the plot to avoid statistical bias related to the eccentricity of the shape of trees.

Following Worbes et al. (2003), core samples were dried and glued on wooden support post. In order to increase visibility of growth zones, cores were polished with fine sand paper of grit size from 80 to 600 .
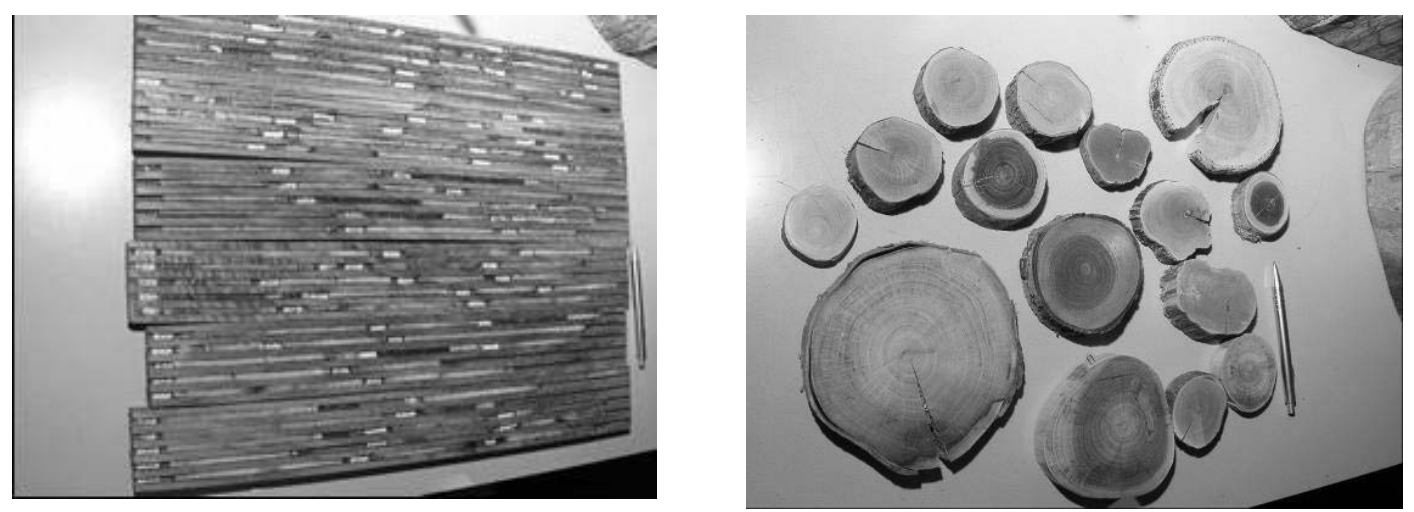

Figure 3-2. Wooden supports and stem discs used for tree ring analysis. 
The ring widths were measured to the nearest $0.01 \mathrm{~mm}$ using a tree ring measurement device following Rinn (Rinn, 1996). Ring measurements were performed along the predetermined radii in a straight line, and generally perpendicular to ring boundaries. Data were processed using the program TSAP (Rinn 1996).

The measured ring-width series of every tree species were cross-dated in order to match variations on the ring widths and find out possible false or absent rings (Fritts, 1976). Cross-dated ring width curves were summarized to mean curves for every selected tree species and recorded for further analysis.

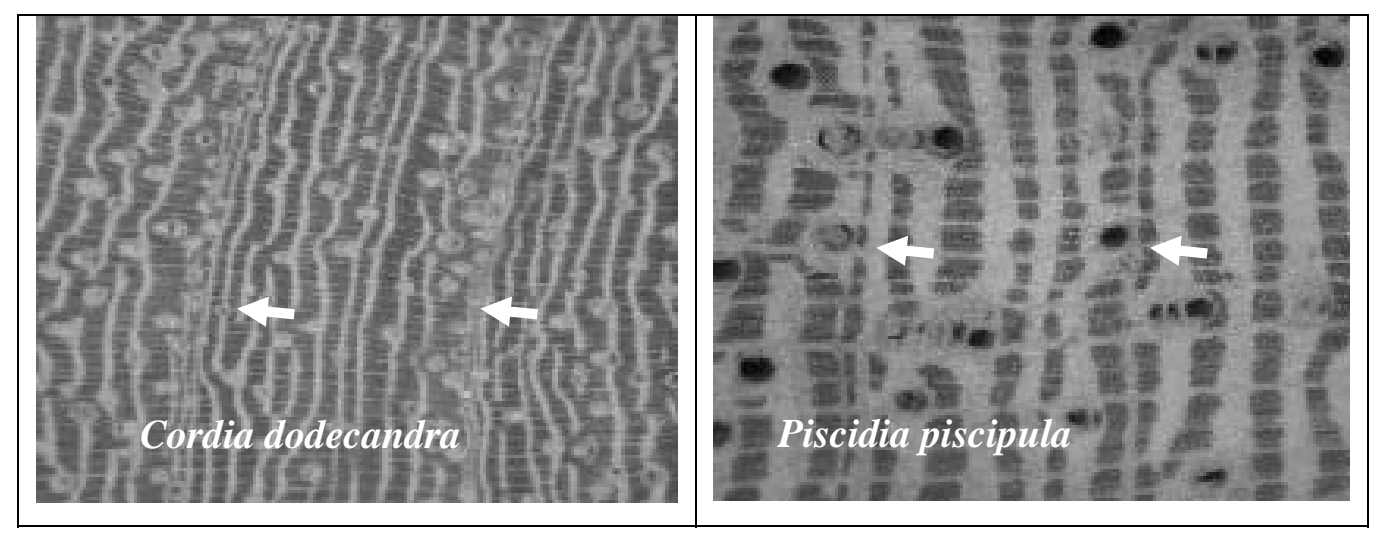

Figure 3-3. Wood anatomy a of selected tree species: Cordia dodecandra and Piscidia piscipula.

In order to present the tree long-term growth data for each study site the cumulative annual diameter growth curves of all measured individuals were calculated for every species separately.

In order to analyze climatic influence on tree growth, three different time series of precipitation from the nearest weather station were calculated:

- Annual precipitation

- Precipitation in the rainy season

- Precipitation in the dry season 


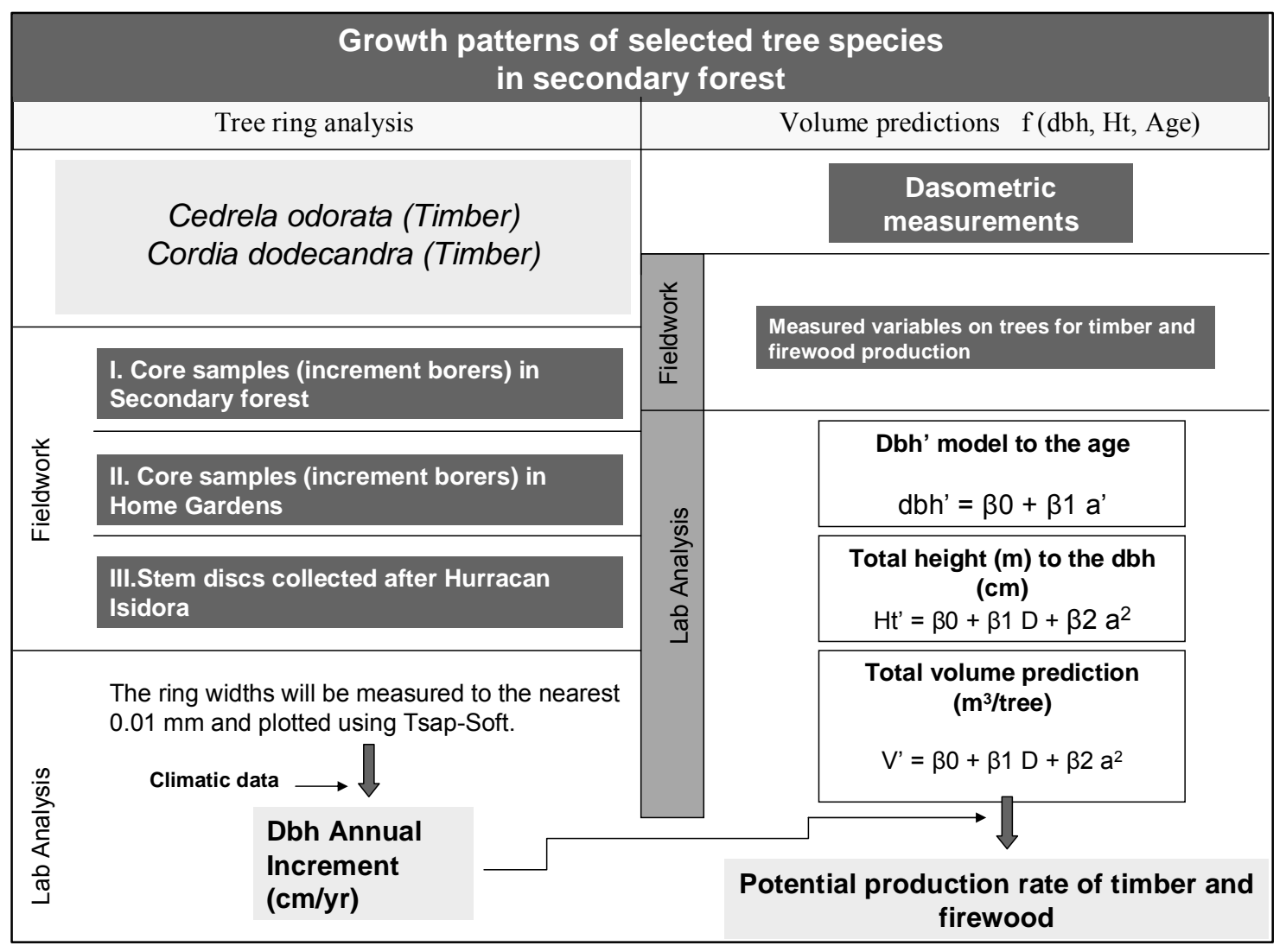

Figure 3-4. Applied methodology to estimate growth patterns of two selected tree species in Northern Yucatan.

Relations of commercial height and dbh were calculated and with this information timber-volume functions were adjusted for each selected species in order to estimate potential rates of timber production. Firewood-volume functions were calculated in a similar way but including volume of branches. In all cases, volume functions were adjusted to the Chapman-Richard's model, and to local models obtained from literature if available.

For this, dbh analysis were used to estimate relative dbh and total height rates. Relative dbh rates were estimated from a set of data collected in the fields which were used to describe the relationship between $\mathrm{dbh}$ and age obtained from the dendrochronological analysis. Trees from 50 plots were fit to the Chapman-Richard's function: 


$$
D^{\prime}=\beta 0\left(1-e^{(-\beta 1(A))) \beta 2}\right)
$$

where $\beta 0, \beta 1$, and $\beta 2$ are parameters to be estimated from the data, $D^{\prime}$ is the estimated $\mathrm{dbh}$ in centimeters and $\mathrm{A}$ is the age in years. The unknown coefficients were estimated via Simplex and quasi-Newton as implemented in StatSoft Inc. (1995).

A lineal equation was adjusted to estimate Total height $(\mathrm{m})$ to $\mathrm{dbh}(\mathrm{cm})$.

$$
\mathrm{Ht}^{\prime}=\beta 0+\beta 1 \mathrm{D}
$$

Where:

$\beta 0$ and $\beta 1$ are parameters

$\mathrm{Ht}$ ' is the estimated total height in meters

And $\mathrm{D}$ is the dbh in centimeter

Estimates of volume of individual trees are based on regression functions from multiple diameter and height measurement of sample trees. Traditionally, volume equation was based on the Schumacher and Hall model transformed to a linear form:

$$
V=\pi \frac{D^{\prime 2}}{40.000} * H_{t} * F f * N
$$

Where:

$\mathrm{V}$ is the stumpage individual volume outside bark ( $\mathrm{m} 3 / \mathrm{ha})$,

D' is the estimated DBH $(\mathrm{cm})$

$\mathrm{H}$ is the estimated Total height $(\mathrm{m})$

$\mathrm{Ff}$ is the form factor $=0.65$

$\mathrm{N}$ is the stand density and

$\Pi$ is the PI value $(3,1416)$ 
The following equation to the age was considered for predicting the total volume per ha at age A:

$$
V=\beta 0(A)+\beta 1\left(A^{2}\right)
$$

Where:

$\mathrm{V}$ is the is the stumpage individual volume outside bark (m3/ha),

A is the age of the tree (yr)

$\mathrm{B} 0$ and $\beta 1$ are parameters

The first derivate of the equeation is:

$$
C A I=\frac{d v}{d a}=\beta 1+2 \beta 1 A
$$

This is known as the instantaneous growth-rate function or the current annual increment (CAI) function. The mean annual increment at the time $t$ in years is equal to:

$$
M A I=\frac{V_{t}}{A_{t}}
$$

and the age of MAI culmination occurs when the first derivate of MAE equals 0 .

\subsection{RESULTS AND DISCUSSION}

\section{Wood Anatomy}

On the highly polished stem discs and the prepared cores, growth zones appear with specific differences in distinctiveness. Piscidia piscipula and Cordia dodecandra show very clear rings, although we encountered several problems with intra-annual growth zones, especially in Cordia. 
Distinctiveness of rings varied between the two study species, but was always sufficiently clear to mark individual rings. The distinctiveness depended on ring width: wide rings were generally distinct, but distinctiveness decreased with a decrease in ring width, e.g. towards the centre of the tree or at very large diameters.

We classified the wood structure of rings according to the classification of Coster (1927) cited by Brienen (2005) and adapted by Worbes (1995). Four types of rings were distinguished in this classification:

- Type 1: Density variations

- Type 2: Marginal parenchyma bands

- Type 3: Repeated pattern of alternating fibre and parenchyma bands and

- Type 4: Variations in vessel distribution and/or vessel size.

Cordia showed differences in vessel distribution (type 4) in combination with (slight) differences in wood coloration and (paratracheal) parenchyma structure (Fig. 3-3). At the beginning of each growth ring a band of fibres without vessels or parenchyma is formed. Towards the end of the growth ring the shape of the paratracheal parenchyma changes from round to flat. Growth rings of Piscidia are marked by a marginal parenchyma band (type 2). In Piscidia this band is always clearly visible (Fig. 3-3).

The form of terminal parenchyma bands in Cordia were the most clear marks to distinguish tree rings, while other types of rings (repeated patterns of parenchyma and fibre bands and variations in wood density) were more difficult to distinguish. This difference was especially apparent at lower growth rates. Generally, the determination of growth rings became less accurate at lower growth rates, i.e. in smaller tree rings.

\section{Tree diameter growth and growth trends of Cordia dodecandra and Piscidia piscipula}

The diameter growth data are important criteria for evaluating site quality, growth performance of the tree species and developing silvicultural systems. In order to present 
the tree long-term growth data for each study site the cumulative annual diameter growth curves of all measured individuals were calculated for every species separately.

As can be seen from figures 3-5 and 3-6 obtained through tree ring analysis for coresamples of Cordia dodecandra and Piscidia piscipula the mean annual growth rates differ from species to species and in all sites. In Piscidia piscipula the mean ring-widths vary between $0.8 \mathrm{~mm}$ per year and $0.6 \mathrm{~mm}$ per year in Cordia alliodora. Tree species of young secondary forest show with $1.2 \mathrm{~mm}$ per year higher annual increment than old secondary forest. This may be the result of prevailing light and soil condition. The old secondary forests have higher stand densities that may be a disadvantage for the initial growth of trees, while the young stand has more openings from previous Sisal and agriculture fields. The latter is expected to improve the growth condition of the remaining trees.

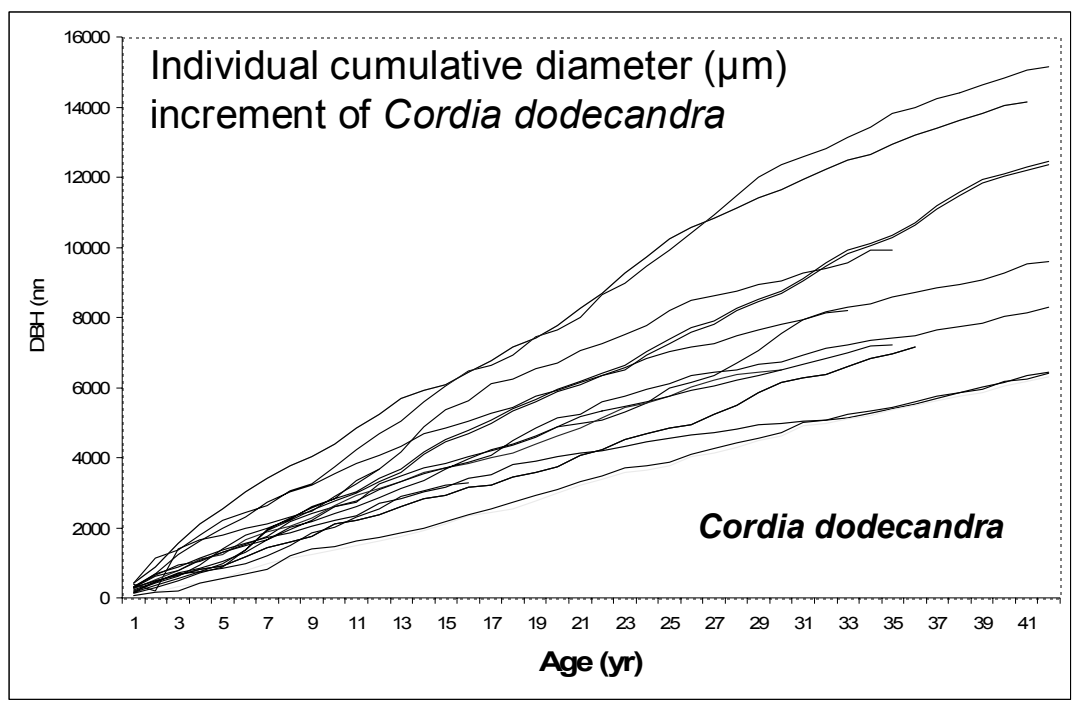

Figure 3-5. Dbh growth rate $(\mathrm{cm})$ obtained through tree ring analysis for core-samples of Cordia dodecandra. 


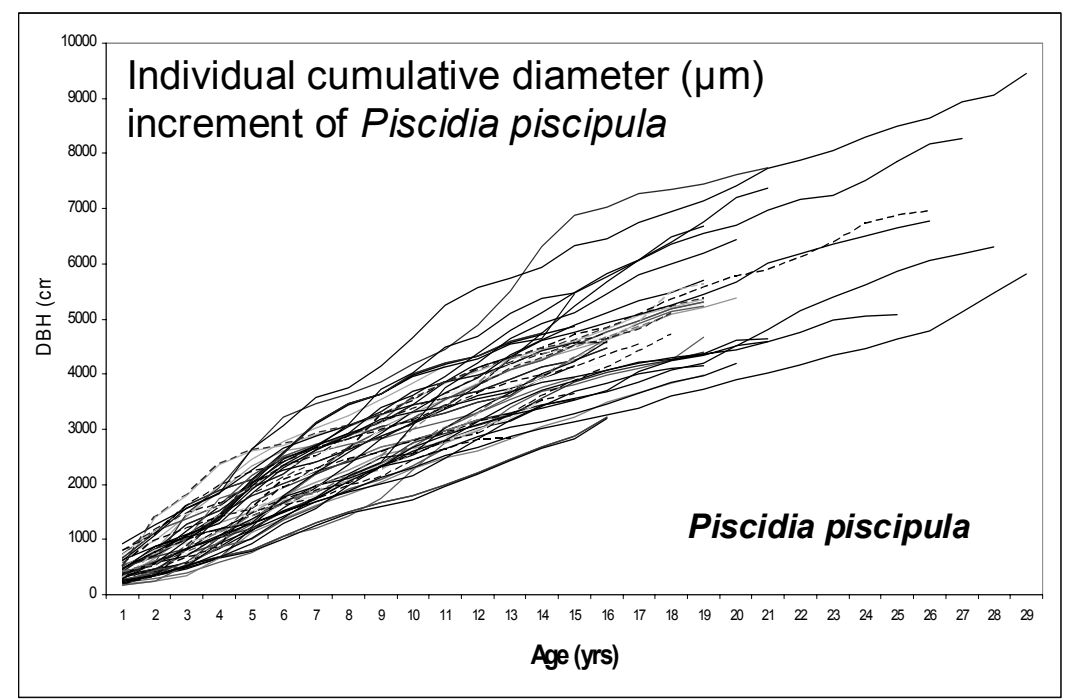

Figure 3-6. Dbh growth rate $(\mathrm{cm})$ obtained through tree ring analysis for core-samples of Piscidia piscipula

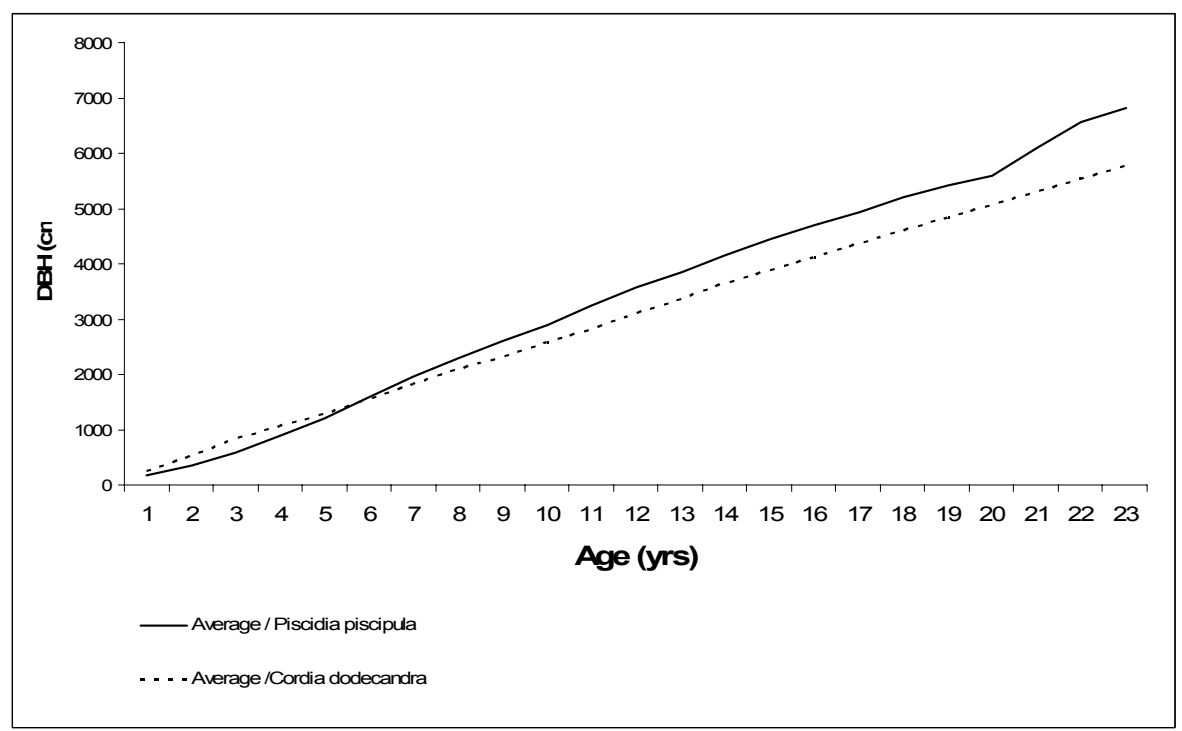

Figure 3-7. Comparison ofmean growth rates $(\mathrm{cm})$ at DBH obtained through tree ring analysis for core-samples of Piscidia piscipula and Cordia dodecandra 


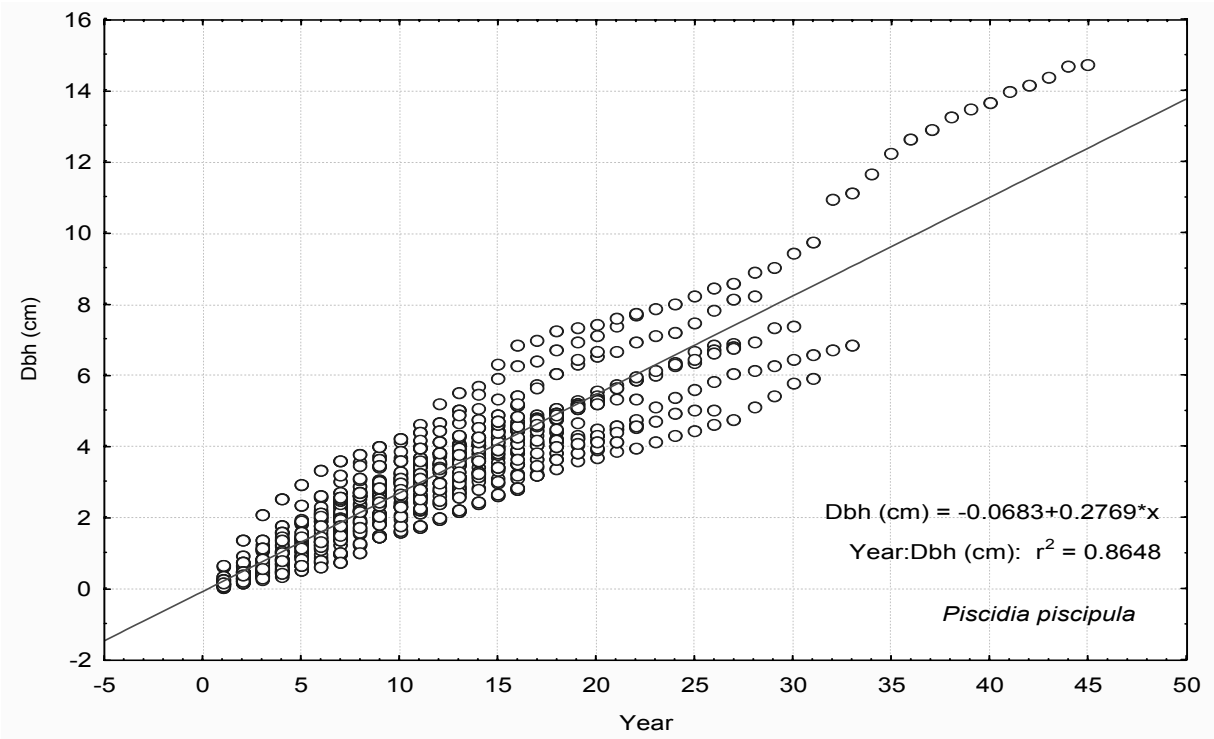

Figure 3-8. Fitted diameter curves of Piscidia piscipula

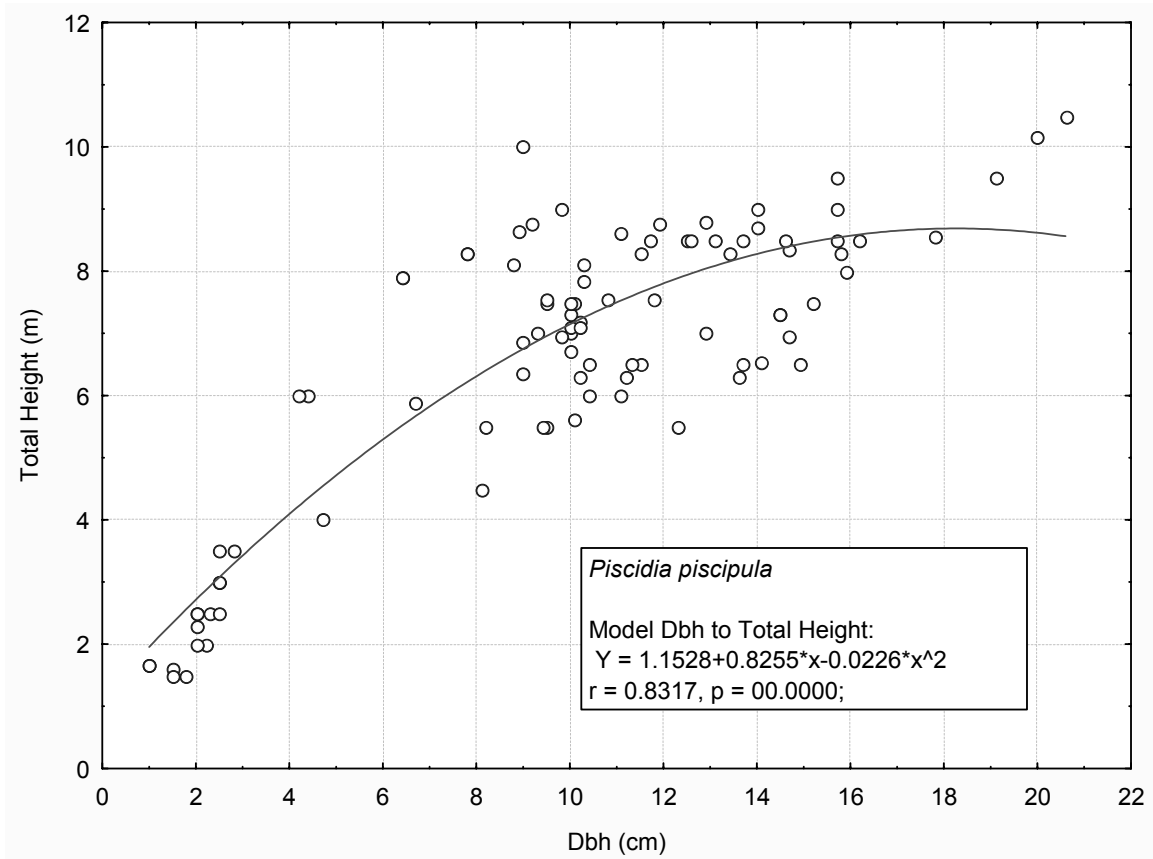

Figure 3-9 Total Height (m) curve to the dbh $(\mathrm{cm})$ 


\section{Relation between precipitation, temperature and growth dynamics}

The possibility to cross-date measured ring with time series is one indication of seasonal growth in tropical trees (Worbes, 1995; Stahle et al., 1999).

The annual tree growth is generally affected by climatic factors, such as: variation of temperature and precipitation. The existence of a dry season with a length from 4 to 5 months and a monthly precipitation less than $50 \mathrm{~mm}$ per month is one factor that may induce annual tree rings in the tropics due to seasonal alternating favorable and unfavorable growth conditions (Fritts, 1976; Worbes, 2001). Within the tropics several studies already showed significant correlations between tree ring widths chronologies with precipitation in different time periods (Worbes, 19993).

In the present study, the precipitation of different time series were correlated with tree ring curves which were summarized for selected species (Cordia and Piscidia) after cross- dating. The results show that in both species, the annual ring indices of tree species showed a significant positive correlation with the total amount of precipitation in the year as well as with the total precipitation in the rainy season (March to October). The parallel variation value (Glk.-value), as a measure for the similarity of two tree ring series, is in all cases comparably high, over $60 \%$. For Piscidia piscipula we found significant correlations between total annual precipitation and annual tree growth. The parallel variation value (Glk.-value, Rinn, F (1996): Worbes et al. (1999)) as a measure for the similarity of a tree ring series was high over $67 \%$. However the correlation between treering width series and total precipitation in the dry season was not significant.

Between the chronologies of Cordia and Piscidia we found significant correlations ( $\mathrm{r}=$ $0.48, \mathrm{p}<0.05)$, which means that these species show a similar growth pattern. For Piscidia the synchrony between the chronology and the highest correlating precipitation period is shown in Figure 3-10. 


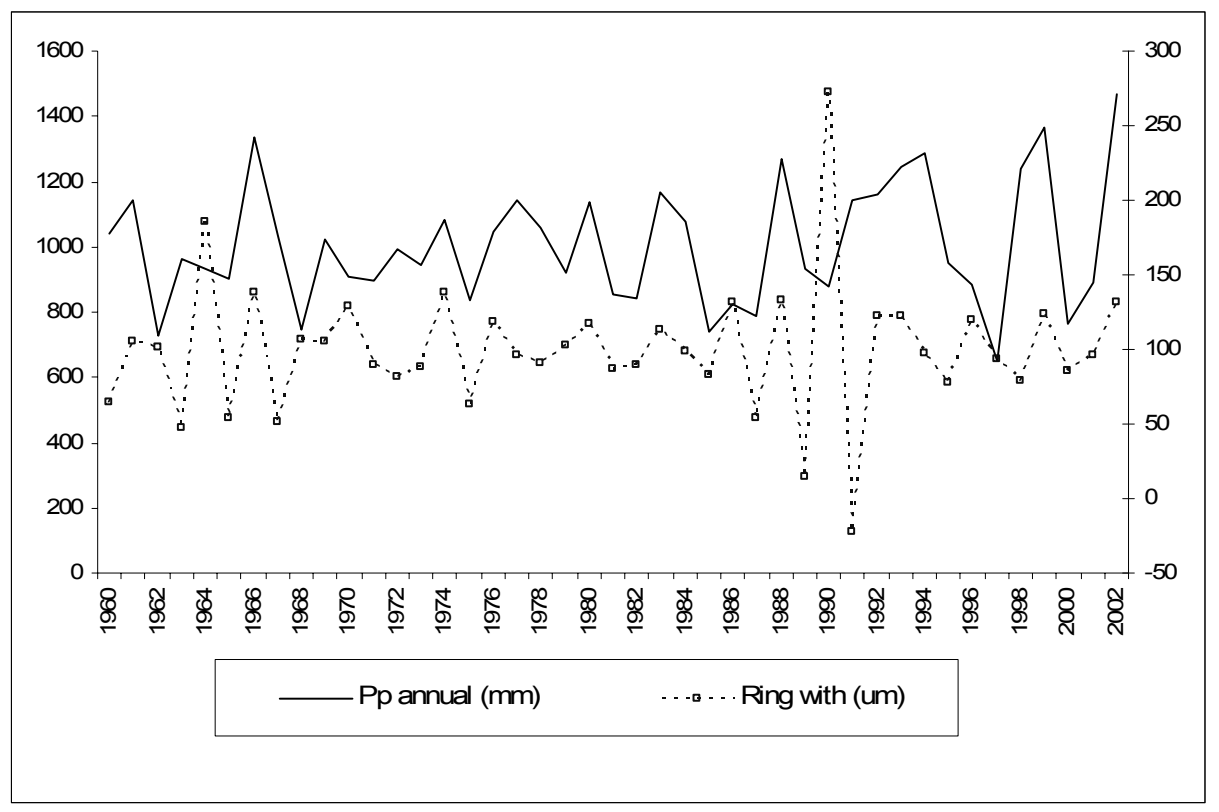

Figure 3-10. Correlation between tree-ring width indices of Piscidia piscipula and precipitation. The parallel variation value (Glk.-value, Rinn, F (1996): Worbes et al. (1999)) as a measure for the similarity of a tree ring series was high over $67 \%$.

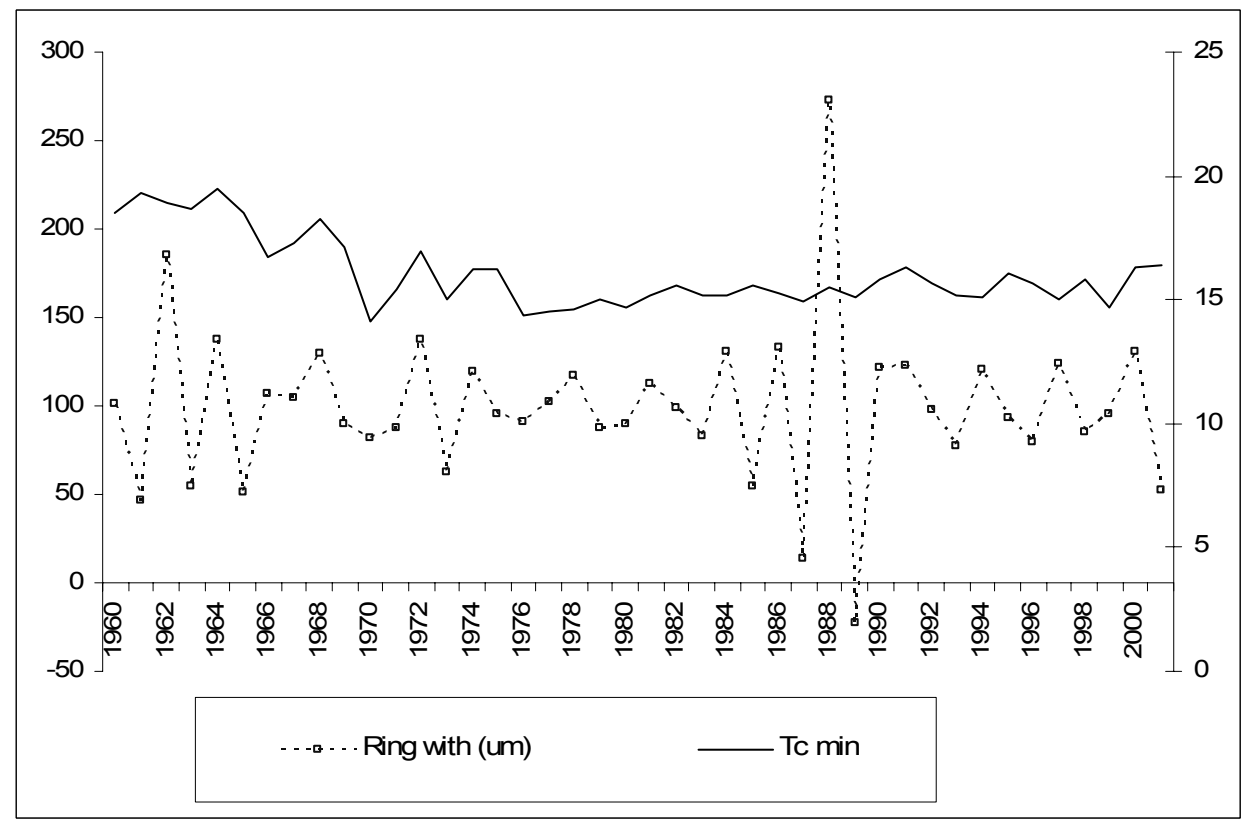

Figure 3-11. Correlation between tree-ring width indices of Piscidia piscipula and temperature. The parallel variation value (Glk.-value, Rinn, F (1996): Worbes et al. (1999)) as a measure for the similarity of two tree ring series, was lower than $60 \%$. 


\subsection{CONCLUSIONS}

In this study, Piscidia showed a positive relation with the annual rainfall and total precipitation in the rainy period at different succession states. Tree species of young secondary forest showed a higher mean annual diameter increment than those from old secondary forest.

Relations between growth and rainfall were generally positive for Cordia and Piscidia, indicating that growth is limited by the amount of rainfall. This demonstrates a positive effect of seasonality in the growth regime of selected tree species. Therefore, we can infer that tree ring in these secondary forests is of annual nature. However, future research should extend the investigation to additional tree species and varying site conditions on further semiarid forests in Northern Yucatan forest to achieve information on growth behaviour of these important ecosystems on sustainable management and future silvicultural approaches. This could be one basis to develop sustainable management operations in order to reserve these endangered ecosystems.

The climatic and vegetation characteristics of Yucatán provide interesting potential for the development of dendrochronological studies. The long dry season occurring between November and April (rainfall amounts to only $30 \%$ of the annual precipitation) results in seasonality of plant growth. Therefore, over almost all of the Peninsula and particularly in the northern side (with extreme arid conditions) the vegetation totally or partially sheds its leaves during the summer months (Flores \& Espejel, 1994). This leaf loss must necessarily influence the activity of the growth tissue (cambium).

The ring distinctiveness and the growth rates we found in this study are comparable to other dendrochronological studies on Yucatec trees (Roig 2004). However, some authors have reported problems in distinctiveness of Piscidia piscipula for dendrocronological analysis (Guadalupe, 2006). 
The tree ring analysis for core-samples of Cordia dodecandra and Piscidia piscipula show that annual growth rates vary between $0.8 \mathrm{~mm}$ per year and $0.6 \mathrm{~mm}$ per year. Tree species of young secondary forest show higher annual increment with $1.2 \mathrm{~mm}$ per year than old secondary forest. This may be the result of prevailing light and soil condition.

According to our predictions (Chapter 2), this secondary forest have the potential to produce an average amount of timber of $0,087 \mathrm{~m}^{3} /$ tree over 50 years old which implies for timber or medium amount of firewood $\left(2,65 \mathrm{~m}^{3} / \mathrm{ha} / \mathrm{yr}\right)$. These values are very low in comparison to other semiarid regions. Mitloehner (2003) reported an annual increment in the Chaco region of Paraguay, under very similar climatic conditions of $2 \mathrm{~m}^{3} / \mathrm{ha} / \mathrm{yr}$.

The old secondary forests have higher stand densities that may be a disadvantage for the initial growth of trees, while the young stand has more openings from previous Sisal and agriculture fields. The latter is expected to improve the growth condition of the remaining trees.

Our study shows that there are several advantages of using tree ring analysis for forest management studies over the standard method that applies growth data from permanent sample plots. Tree ring analysis yields direct values for ages and lifetime growth rates and is therefore more accurate than extrapolations based on short-term growth data. Furthermore, ring analysis over short-term growth measurements is the opportunity to quantify variation in growth among individuals over long periods of time.

The data presented above suggest two major strategies for future work. One would be to focus on those species with distinct and annual growth rings, which could be used for dendrochronological studies. Such species could be used to provide data on tree ages and dating of stands and/or field plots with additional possibilities for reconstructing of climate records in some cases. 


\subsection{REFERENCES}

Alvim, R. 1978. Relation of climate to growth periodicity in tropical trees. In: Tomlinson PB, Zimmermann MH (eds) Tropical trees as living systems. Cambridge University Press, London, pp 445-464.

Brienen R. y P. Zuidema. 2005. Relating tree growth to rainfall in Bolivian rain forests: a test for six species using ring análisis. Oecologia. 146: 1-12.

Borchert R., 1999. Climatic periodicity, phenology, and cambium activity in tropical dry forest trees.IAWA Journal 20:239-247.

Canham C., 1985. Suppression and release during canopy recruitment in Acer saccharum. Bull. Torrey Bot. Club 112:145.

Caballero G., P. 1990. Contribución al conocimiento dendroenergético y forrajero de dos especies del bosque tropical caducifolio. Tesis de licenciatura. UACH. Chapingo, México.

Campo, J. and C. Vázquez-Yanes. 2004. Effects off nutrient limitation on aboveground Carbon dynamics during Tropical Dry Forest Regeneration in Yucatán, México. ESOSYSTEMS 7: 311-319.

Campo, J. y Dirzo, R. In press. Leaf quality and hervibory respons to soil nutrient addition in secondary tropical dry forests of Yucatán, México. J. Trop. Ecology.

Campo, J., Maas, J., Jaramillo, V.J., Martínez-Yrízar, A., Sarukhán, J. 2001. Phosphorus cycling in a Mexican tropical dry forest ecosystem. Biogeochemistry 53, 161-179.

Chazdon RL, Pearcy RW, Lee DW, Fetcher N, 1996. Photosynthetic responses of tropical forest plants to contrasting light environments. In: Mulkey SS, Chazdon RL, 
Smith AP (eds) Tropical plant forest ecophysiology. Chapman \& Hall, New York, pp 555.

Clark DA, Clark DB, 1992. Life-history diversity of canopy and emergent trees in a neotropical rainforest. Ecological Monographs 62:315-344.

Clark DA, Clark DB, 1999. Assessing the growth of tropical rain forest trees: Issues for forest modeling and management. Ecological Applications 9:981-997.

Condit R, Hubbel SP, Foster RB. 1995b. Mortality-rates of 205 neotropical tree and shrub species and the impact of a severe drought. Ecological Monographs 65:419-439.

Dezzeo N, Worbes M, Ishii I \& Herrera R., 2003. Annual tree rings revealed by radiocarbon dating in seasonally flooded forest of the Mapire River, a tributary of the lower Orinoco River, Venezuela. Plant Ecology 168:165-175.

eNature, 2001. Information about the wild animals and plants. Available in 09.2007. at http://www.enature.com.

Flores O and P Gerez, 1994. Biodiversidad y conservación en México: vertebrados, vegetación y uso del suelo. Comisión Nacional para el Conocimiento y Uso de la Biodiversidad and Universidad Autonoma de México, Mexico

Gómez-Pompa, Arturo, Michael F. Allen, Scott L. Fedick, Juan J. Jiménez-Osornio, J. 2003. Lowland Maya Area: Three Millennia at the Human-Wildland Interface. New York: Haworth Press.

Jankiewicz LS, Colinas León MT and VM Martinez Albores, 1986. Cupapé (Cordia dodecandra DC, Boraginaceae) a fruit tree in the process of domestication in Mexico. Acta Societatis Botanicorum Poloniae 55 (1): 115-127. 
Jimenez Osornio,J, B. Luckman, A. Medina, E. Noellemeyer, F. Roig, H. Tiessen and J. Villanueva. 2003. Exploratory dendrochronological work on trees in the land use system of Yucatan. Progress report from a cooperative initiative between IAI-CRN 001 and 003.

Enright, N.J. \& Hartshorn, G.S. 1981. The demography of tree species in undisturbed tropical rainforest. Journal of Vegetation Science, Vol. 10, No. 6 (Dec., 1999), pp. 793804.

González-Iturbe, J. A. Olmsted y Tun-Dzul, F. 2002. Tropical dry forest recovery alter long term Sisal (Agave fourcroydes Len.) plantation in northern Yucatán, México. Forest Ecology and Management. 167: 67-82.

Hartshorn GS., 1978. Tree falls and tropical dynamics. In: Tomlinson PB, Zimmermann MH (eds) Tropical Trees as Living Systems. Cambridge University Press, Cambridge, pp $617-638$

Landis RM., 1999. Juvenile tree response to canopy-structure: population and community-level implications in a subalpine forest of the northeastern U.S. PhD thesis, Dartmouth College, Hanover, New Hampshire, U.S.A. 111 pp.

Lawrence, D. \& David Foster, 2002. Changes in forest biomass, litter dynamics and soils following shifting cultivation in Southern Mexico: an overview. Intercience Journal. VOL. $27 \mathrm{~N}^{\circ} 8$.

Lieberman D, Lieberman M, Hartshorn GS, Peralta R, 1985a. Growth rates and age-size relationships of tropical wet forest trees in Costa Rica. Journal of Tropical Ecology 1:97109.

Lorimer CG, Frelich LE, Nordheim EV., 1988. Estimating gap probabilities for canopy trees. Ecology 69:778-785. 
Mizrahi, P.A; P.J.M Ramos y O.J.J. Jiménez. 1996. Composición, estructura y manejo potencial de la vegetación secundaria de selva seca en dos plantaciones abandonadas de henequén.

Montañez P, Jiménez-Osornio JJ, Durán R and E Cuevas, 2001. Litter and nutrient production in homegardens in two Maya communities from Yucatan, Mexico. Poster presentation, Facultad de Medicina Veterinaria, Universidad Autónoma de Yucatán, Mexico

Murphy P.G. y A.E. Lugo. 1986. Ecology of dry tropic forest. Ann. Rev. Ecol. Syst. 17: $67-88$.

Pennington TD and J Sarukhan., 1998. Arboles tropicales de México. 2nd ed., Universidad Nacional Autonoma de Mexico, Mexico City, Mexico Poorter L (1998) Seedling growth of Bolivian rain forest tree species in relation to light and wáter availability. Utrecht University, PROMAB scientific series 1. 195 pp.

Poorter L., 1999. Growth responses of 15 rain-forest tree species to a light gradient: the relative importance of morphological and physiological traits. Functional Ecology 13:396-410.

Poorter L, Werger MJA, 1999. Light environment, sapling architecture, and leaf display in six rain forest tree species. American Journal of Botany 86:1464-1473.

Poorter L, Boot RGA, Hayashida-Oliver Y, Leigue J, Peña-Claros M, Zuidema PA 2001. Estructura y dinámica de un bosque húmedo tropical en el norte de la amazonía Boliviana. PROMAB, Informe técnico No. 2. pp 54.

Poorter L, Arets EJMM, 2003. Light environment and tree strategies in a Bolivian tropical moist forest: an evaluation of the light partitioning hypothesis. Plant Ecology 166:295-306. 
Poorter L, Bongers F, Sterck F, Woll H. 2005. Beyond the regeneration phase: differentiation of height-light growth trajectories among tropical tree species. Journal of Ecology 93:256-267.

Read L, Lawrence D (in press) Recovery of biomass following shifting cultivation in dry tropical forests of the Yucatan. Ecological Applications.

Read L, Lawrence D (Submitted). Litter nutrientdynamics in secondary dry tropical forests.

Roig, F. A. 2000. Dendrocronología en los bosques del Neotrópico: revisión y prospección futura.In: Roig FA, editor. Dendrochronology in Latin America. Mendoza: EDIUNC. Pp 307-355.

Roig, F. A. (2005). Anatomy of growth rings at the Yucatán Península. Dendrochronologia 22. pp 187-193.

Schongart J, Piedade MTF, Ludwigshausen S \& Worbes M. 2002. Phenology and stemgrowth periodicity of tree species in Amazonian floodplain forests. Journal of Tropical Ecology 18:1-17.

Stahle DW. 1999. Useful strategies for the development of tropical tree-ring chronologies. IAWA Journal 20:249-253

Swaine MD, Whitmore TC, 1988. On the definition of ecological species groups in tropical rain forests. Vegetatio 75:81-86.

Scheweingruber F. H. 1986. Abrupt growth changes in conifers. - IAWA Bulletin n. s. 7(4): 277-283. 
Villalba, R. 2000. Dendroclimatology: a Southern Hemisphere Perspective. Paleo- and Neoclimates of the Southern Hemisphere: the state of the arts. P. Smolka and W. Volkheimer (eds.). Springer, Germany.

Vlek, P.L.G., G. Rodríguez-Kuhl and R. Sommer. 2004. Energy use and CO2 production in tropical agriculture amd means and strategies for reduction or mitigation. Environment, Development and Sustainability, 6 (1-2): 213-233.

Whitmore TC, 1998. An introduction to tropical rain forests. Oxford University Press, New York.

Worbes M, 2002. One hundred years of tree-ring research in the tropics- a brief history and an outlook to future challenges. Dendrochronologia 20:217-231.

Worbes M, 1995. How to measure growth dynamics in tropical trees - A review. IAWA Journal 16:337-351.

Worbes M, 1999. Annual growth rings, rainfall-dependent growth and long-term growth patterns of tropical trees from the Caparo Forest Reserve in Venezuela. Journal of Ecology 87:391-403.

Worbes M, Junk WJ, 1989. Dating tropical trees by means of C-14 from bomb tests. Ecology 70:503- 507.

Worbes M, Junk WJ, 1999. How old are tropical trees? The persistence of a myth. IAWA Journal 20:255-260.

Worbes M, Staschel R, Roloff A, Junk WJ, 2003. Tree ring analysis reveals age structure, dynamics and wood production of a natural forest stand in Cameroon. Forest Ecology and Management 173:105-123. 


\section{CHAPTER 4: LIMITING FACTORS ON FINE ROOT PRODUCTION SYSTEMS IN SECONDARY FOREST AND INITIAL GROWTH PERFORMANCE OF SEEDLINGS IN THE NURSERY}

\subsection{ABSTRACT}

In this study we used the root-ingrowth technique proposed by Cuevas and Medina (1988) and tested by Raich et al., (1994) to determine fine root biomass production with $N, P$ and $K$ fertilization treatments on black and red soils in a $35 \mathrm{yr}$ old secondary forest in Northern Yucatan. To validate these results, we conducted a second experiment with Cordia dodecandra to identify limiting $P$ and $N$ on black and red soils at a nursery stage. The results from the first experiment (root-ingrowths) show that additions of $K$ and $P$ caused a substantial increase in fine root production. In an overall ANOVA on biomass root increments, we observed a significant effect of K addition, a moderate effect of $P$, especially in red soils, with no effect of $N$. The results from the second experiment (using Cordia dodecandra seedlings in a nursery) show the fertilizer application enhanced the seedling height after 6 months. The mean height of seedlings in $P$ additions were about 6,1 and 3,1 cm more than the control in black and red soils. These experiments imply that plant production generally should be limited by $P$ on red and black soils; $N$ supply should near adequate on intermediate-aged forest.

Keywords: Root-ingrowth, root biomass production Cordia dodecandra

\subsection{INTRODUCTION}

Forest growth is often limited by low levels of nutrient availability, as evidenced by numerous experimental studies and field trials (Binkley, 1996; Raich et al., 1994). Most such studies have been carried out to guide or evaluate forest fertilization programs, but knowing which nutrients limit forest growth also contributes to the basic understanding of forest ecosystems. A knowledge of which nutrients limits growth in different forest types and on different soils is important at the global scale. The potential effects of global environmental changes on forest productivity depend, in part, on the extent of $\mathrm{N}$ limitation in different forest (Pastor and Post, 1988, McGuire, 1992, Raich et al., 1994). 
The knowledge on nutrient requirements of tropical dry forest in Northern Yucatan is still scarce. The only way to determine unambiguously which nutrients limit forest growth is with fertilization experiments. However, forest fertilization is expensive, labor intensive, slow to yield results, difficult to interpret in mixed-species stands and may alter the vegetation being studied. A number of methods have been used to infer nutrient limitation from simpler measurements. These include foliar analysis, plant-growth bioassays analysis in litter fall, and determinations of soil nutrient-supplying capacity (Raich et al., 1994). These approaches have proved useful in specific situations, but without calibrations against fertilizer experiments they can only suggest the existence of limitation by a particular nutrient.

Fine roots $(<2 \mathrm{~mm}$ diameter) play important roles in water and nutrient absorption and are the important structural and functional components of forested ecosystems (Persson 1983, Cheng and Bledsoe 2002, Jaehong and Son, 1993). In order to understand belowground nutrients flux mechanism, it is important to determine temporal and spatial distributions of fine roots. However, due to difficulties in measuring fine root growth, current information about fine root dynamics is limited (Majdi, 1996). A large proportion of forest production is allocated to fine roots, resulting in a large flux of carbon and nutrients into belowground system (Marshall 1986, Kurz et al. 1996, Cairns et al. 1997). Also, fine root turnover represents a major pathway for carbon and nutrient fluxes from plants to soils, but it is not easily or commonly measured (Dilustro et al. 2002). Although tree root systems store large amounts of organic matter and nutrients in forest ecosystems, information on the rates and controls of fine root decomposition is scant, especially compared with the aboveground litter decomposition (Fogel and Cromack 1977, Chen et al. 2002).

Fertilization is a routine operation in forest management in many regions, and nitrogen $(\mathrm{N})$ and phosphorus (P) are the primary elements used. The impacts of fertilization on fine root dynamics depend on a wide range of factors, including stand composition and structure, and the rate and form of fertilizer (Jaehong and Son, 1993).

There are numerous studies on the effects of fertilization on fine root biomass and production in forests, however, the results are still conflicting in the literature (Hendricks et al. 1993). For 
example, some studies reported increased fine root biomass and production following fertilization (Braekke 1992, Helmisaari and Hallbacken 1999, Majdi 2001). In contrast, the other studies showed that the fine roots responded to fertilization with lower biomass and production (Alexander and Fairley 1983, Gower et al . 1992, Majdi and Nylund 1996).

Fine roots often respond to nutrient-rich microsites by proliferating in the nutrient-rich path (Raich et al., 1994). Cuevas and Medina (1988) suggested that this growth response may be specific to particular limiting nutrient and hence, could be used as an assay for nutrient limitation. Using this approach, Cuevas and Medina (1988) demonstrate that roots in an Amazonian forest responded to added $\mathrm{P}$ and $\mathrm{Ca}$, roots in a Mountain forest responded to $\mathrm{N}$ and P. These results were consistent with patterns of nutrient concentrations and circulation in these contrasting forest (Cuevas and Medina, 1988), but no fertilization trials were conducted to validate their results.

The root-ingrowths bioassay proposed by Cuevas and Medina (1988) is relatively rapid and straightforward to apply: if it proves reliable it will be a useful technique for identifying nutrient limitation in forest. We tested this method in a deciduous dry forest in Northern Yucatan.

The purpose of this study was to determine fine root biomass production with $\mathrm{N}, \mathrm{P}$ and $\mathrm{K}$ fertilization treatments on black and red soils in a 35-yr secondary forest in Xmatkuil, Merida. To validate these results, we conducted a trial with Cordia sp. to identify limiting factors on black and red soils at a nursery stage. In both cases, we used a factorial design with two soil types and two fertilizers. Here, we present results for the intermediate-aged site, and compare results with the second experiment to explain patterns of $\mathrm{N}, \mathrm{K}$ and $\mathrm{P}$ limitation during ecosystem development.

\section{Objective}

To evaluate nutrient limitation in secondary forest and the effect of nutrient enrichment on its root growth. 


\section{Research questions}

1) What are the accumulation rates of fine root biomass in secondary forest?

2) What are the nutrients that limit growth and development of fine root systems?

\section{Hypotheses}

$\mathrm{H} 1$ : N, K or P are limiting factors in Red and Black soils for fine root production

$\mathrm{H} 2$ : $\mathrm{N}, \mathrm{K}$ or $\mathrm{P}$ are limiting factors in Red and Black soils for establishment of Cordia dodecandra plantations.

\subsection{MATERIALS AND METHODS}

\section{Study area}

The Yucatan Peninsula is located in southern Mexico, comprising the States of Yucatan, Quintana Roo and Campeche. The area of abandoned Agave fourcroydes plantations for sisal production is situated in the northern part of the Peninsula, in the State of Yucatan (Nickel, 1995). The high percentage of stones and rock fragments of Yucatan soils combined with the absence of aboveground rivers and creeks present a challenge for agricultural land use.

The experimental plots were situated in the center of the Henequen area in X'matkuil, located $15.5 \mathrm{~km}$ South from Mérida at the Faculty of Veterinary Sciences of the Autonomous University of Yucatan located approximately $5 \mathrm{~km}$ in the neighborhood of the village X'matkuil $\left(20^{\circ} 45^{\prime} \mathrm{N}\right.$, $89^{\circ} 45^{\prime} \mathrm{W}$ ) where the Veterinary Faculty is situated.

The area where the root ingrowth cylinders were established consists of a natural 35 year succession of secondary vegetation that reaches a height of 10-15 meters. It comes from a former sisal plantation that was abandoned.

The topography of the area is characterized by a typical karstic landscape where solid calcareous bedrock conforming an undulating relief. In the microrelief, a mosaic of two soil types exists within few meters, lithosols, black, shallow, stony soils and rendzinas red and deep. They are called in Maya Tzequel and Kankab respectively. Black soils are found near rock outcrops 
whereas red soils are found in the slight depressions between the outcrops (Weisbach et al. 2002).

The forests grow on a flat terrain $(<40 \mathrm{~m}$ above sea level), composed of limestone of coraline origin. Soils are generally young and of calcareous origin; and drainage is extensive, thus the soils hardly ever flood (CICY, 1993). Dominant vegetative species are: tsalam (Lysiloma bahamensis) and jabín (Piscidia piscipula), Acacia gaumeri, Bursera simaruba and Lonchocarpus xuul in other areas. The accompanying species are Vitex gaumeri, Brosimum alicastrum, Caesalpinia gaumeri, Ceiba pentandra and Sideroxylon fuetidissimum. Common cactus species include: Cephalocereus gaumeri, Pterocereus gaumeri and Lemaireocereus griseus. Herbaceous plants, epiphytes and fungi are rather scarce, but bromeliads like Tillandsia do grow on some trees.

\section{Experiment 1: limiting factors in Red and Black soils for fine root production}

Based on the approach of Cuevas and Medina (1988) and Raich et al. (1994), ingrowth cores were installed $12 \mathrm{~cm}$ tall and $10 \mathrm{~cm}$ diameter in soil. The $32 \mathrm{In}$-growth cylinders were installed in a $35 \mathrm{yr}$ old forest in order to quantify rates of fine root accumulation after one rainy season using different fertilizers.

All cores were located at least $1 \mathrm{~m}$ away from the stem to avoid possible variation in coarse root biomass (Fredericksen and Zedaker 1995). Live and dead fine roots $(<2 \mathrm{~mm})$ washed free of soil and total oven dry weights measured.

The cylinders were filled with sieved and root-free soil. The filled cores were installed in locations that had never been fertilized. The filled cores were then dosed with: Triple Superphosphate (00-46-00, 0.5 g/core), Potassium Chloride (KCL 2 g/L) and Urea (46-00-000, 0.5 $\mathrm{g} /$ core) and a control core (same procedure without fertilizer). These dosis are equivalent fertilization rates of $50 \mathrm{~g} / \mathrm{m}^{2}$ of $\mathrm{N}, \mathrm{P}$ or $\mathrm{K}$. Cores were put in place by removing 7,5 cm diameter, $10 \mathrm{~cm}$ deep plug of the surface horizon of soil, inserting the core, and placing the top $1 \mathrm{~cm}$ of soil back to top (Raich et al., 1994). 
We utilized a stratified block design with blocks of four cores, one from each treatment, all four cores being within $0.5 \mathrm{~m}$ of each other. There were, therefore, 8 cores per treatment and soil type with 2 repetitions which account in total 32 cores. Following Raich et al. (1994), blocks of cores were placed at each of two randomly selected distances every $10 \mathrm{~m}$ along each of five randomly located, $30 \mathrm{~m}$ transects in the forest. Blocks were removed from transects, at approximately 6 months interval, woody debris was removed by hand. Sorting and washing of roots required an average of one hour per core. After removal, all live and dead roots were washed free of soil and oven dry weights were measured.

This technique differs from Cuevas and Medina (1988) and from Raich et al. (1994) in that they used vermiculite or calcined clay to fill their cores. We used the soils that were located where the cores were placed, maintaining its original soil type but free of roots.

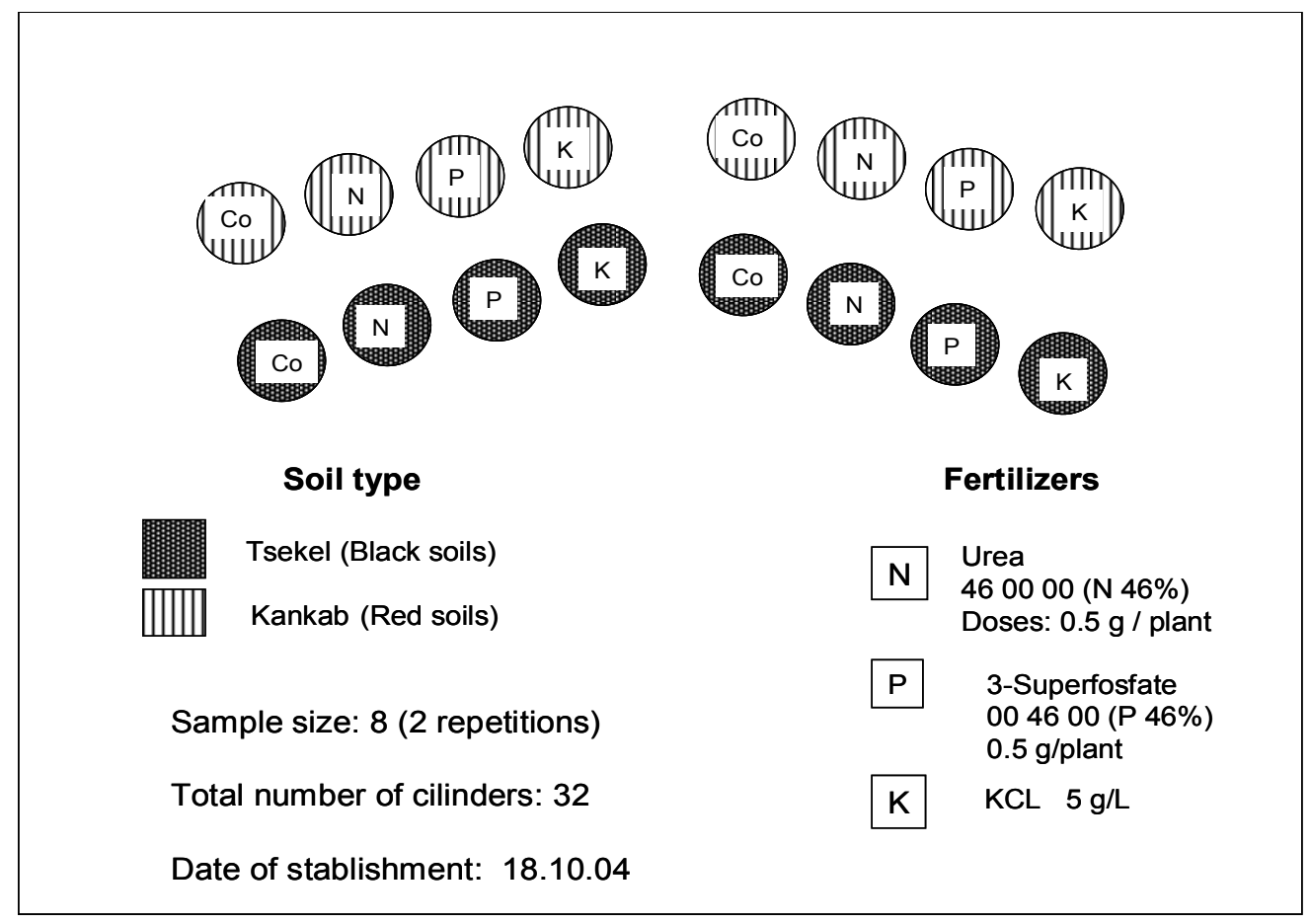

Figure 4-1. Experiment design applied in the ingrowth cylinder experiment. 


\section{Experiment 2: limiting factors in Red and Black soils for establishment of Cordia dodecandra}

plantations

A trial with Cordia sp. was conducted to determine the limiting factors on black and red soils at a nursery stage. The experiment was carried out at the nursery of the Faculty of Veterinary Sciences of the Autonomous University of Yucatan from October 2004 to June 2005. A completely randomized block design was followed with two soil types and two fertilizers including no fertilizer as control. Urea $(46 \% \mathrm{~N}, 150 \mathrm{ppm})$ and Super Phosphate $\left(14 \% \mathrm{P}_{2} \mathrm{O}_{5}, 40\right.$ ppm) were used. Black and red soils, were collected from a $35 \mathrm{yr}$ forest. Soils were sieved free of roots and stones and then plugged into plastic bags. Seeds were collected from same mother tree in order to avoid genetic interference. High quality seedlings were selected for successful cultivation. Young healthy seedlings of $40-50 \mathrm{~cm}$ height, with the first foliage leaf unexpanded and good root system were selected. All seedlings were placed under $80 \%$ light intensity. Seedlings were periodically irrigated, every 3 days, homogeneously in all treatments and control.

Dbh and total height were measured at the beginning of the experiment and after six months in order to estimate increment growth.

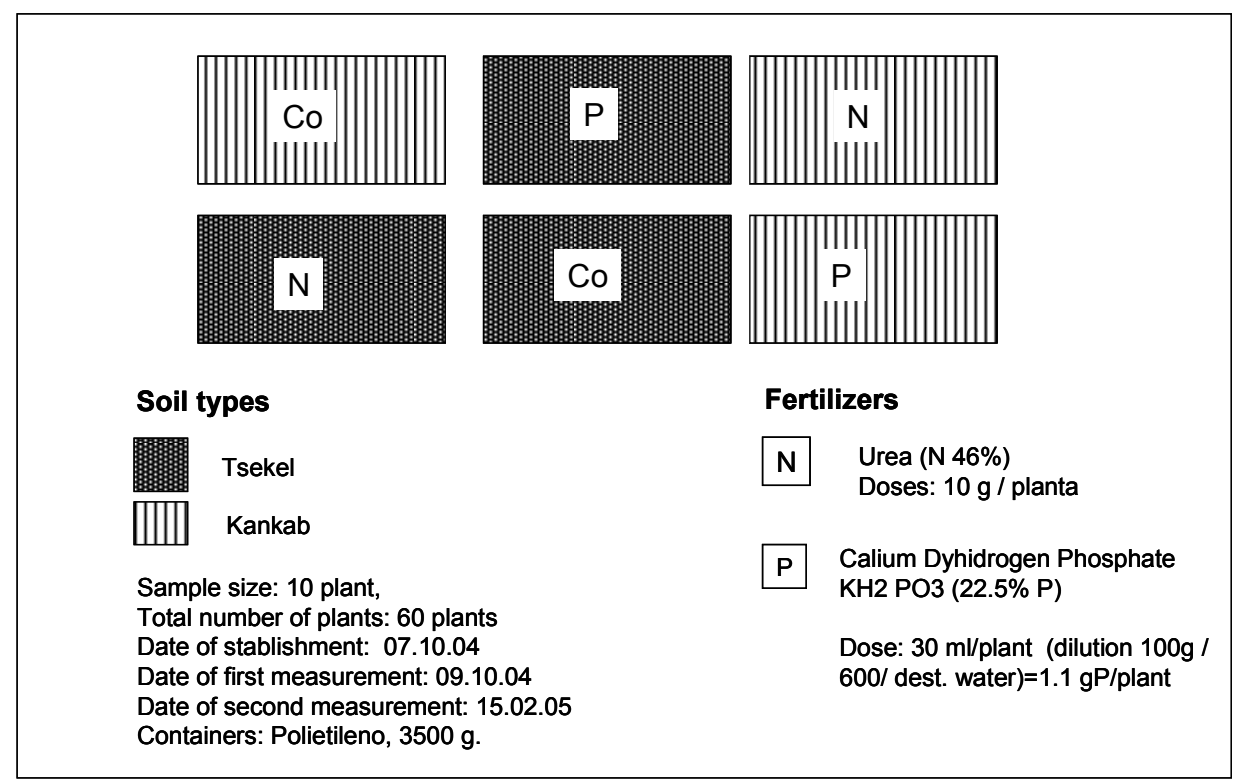

Figure 4-2. Experiment design applied in the Cordia sp. experiment. 


\section{Statistical analysis}

All yield and nutrient data were compared by analyses of variance using a randomized complete block design (ANOVA of STATISTICA Version 5). The nutrient leaching values were compared using a completely randomized design of the logarithmic values due to missing data and homogeneity of variances.

The effect of position was computed as a split plot design (Little and Hills, 1978). In case of significant effects, individual means were compared with a multiple comparison of means using the Tukey test, unless indicated otherwise.

\subsection{RESULTS}

In experiment 1 , cores dosed with $\mathrm{N}, \mathrm{K}$ or $\mathrm{P}$ show clear differences in terms of fine root biomass production and shown clear differences in the two soil types.

Root-growth comparisons among nutrient treatments were based on the dry weight of fine roots that accumulated in each cylinder. All roots were $<2 \mathrm{~mm}$ in diameter. There were very few dead roots in any cores similar to what Raich et al. (1994) reported in their experiment. Results of the experiment are summarized in Table 4-1.

The dry mass of roots that accumulated in the cores was not normally distributed (KolmogorovSmirnov one-sample test) and the treatments did not have homogeneous variances (Bartlett's test). Result was therefore compared using Fisher method for randomized blocks.

Rates of fine root accumulation in the cores varied significantly among treatments $(p<0.005)$ after 6 months. Soil types were not statistically significant different $(\mathrm{p}<0.10)$. K fertilizer differences were statistically significant to $\mathrm{N}$ and control $(\mathrm{Co})$. $\mathrm{P}$ fertilizer differences were statistically significantly different from the control. Additions of $\mathrm{K}$ and $\mathrm{P}$ caused a substantial increase in fine root production. In an overall ANOVA on biomass root increments, we observed 
a significant effect of $\mathrm{K}$ addition, a moderate effect of $\mathrm{P}$, especially in red soils, with no effect of $\mathrm{N}$ or Co interaction.

Table 4-1. Fertilization effects on fine root production.

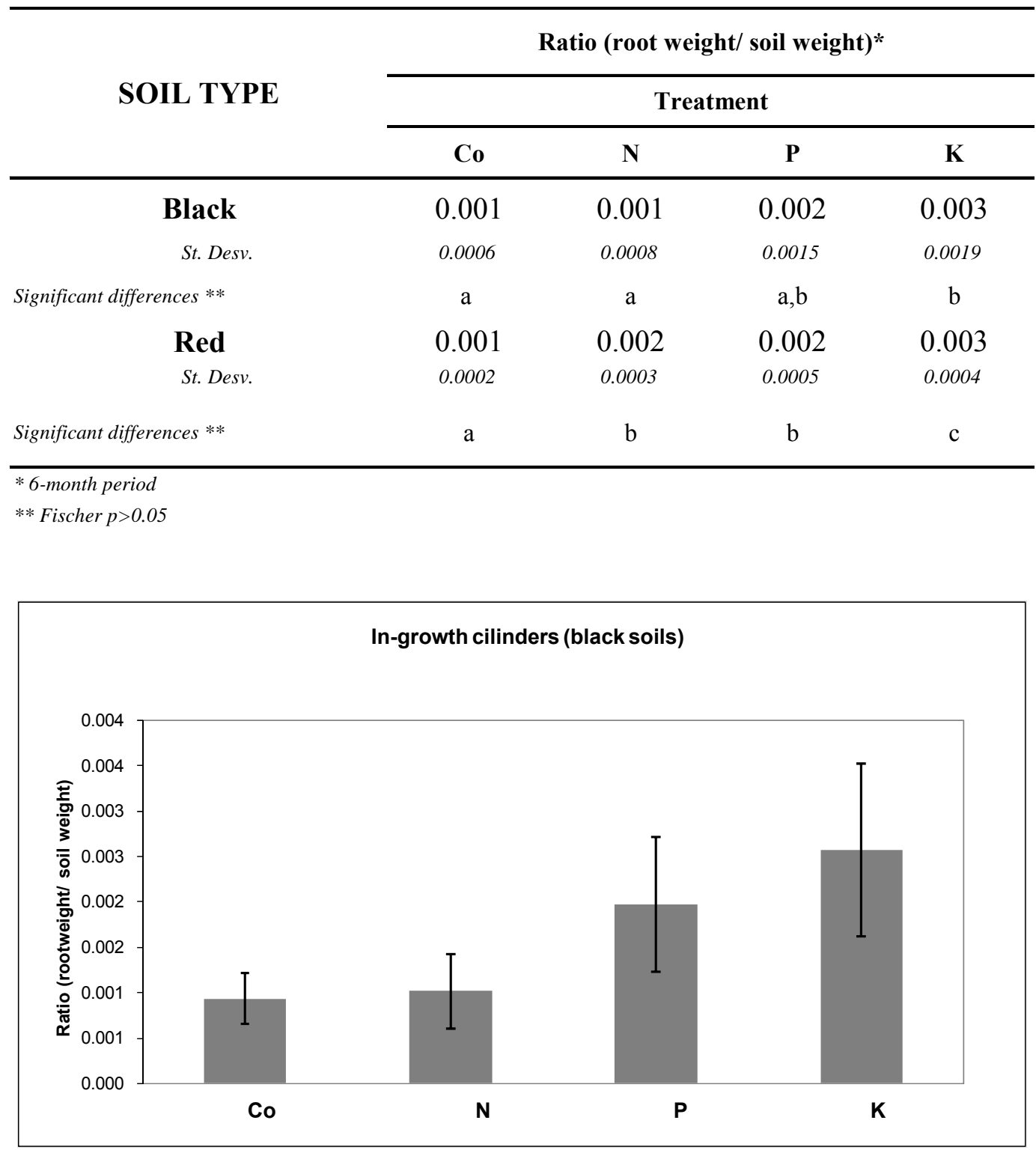

Figure 4-3. Accumulation rates of fine root biomass, in black soils of the dry forest in Northern Yucatan. 


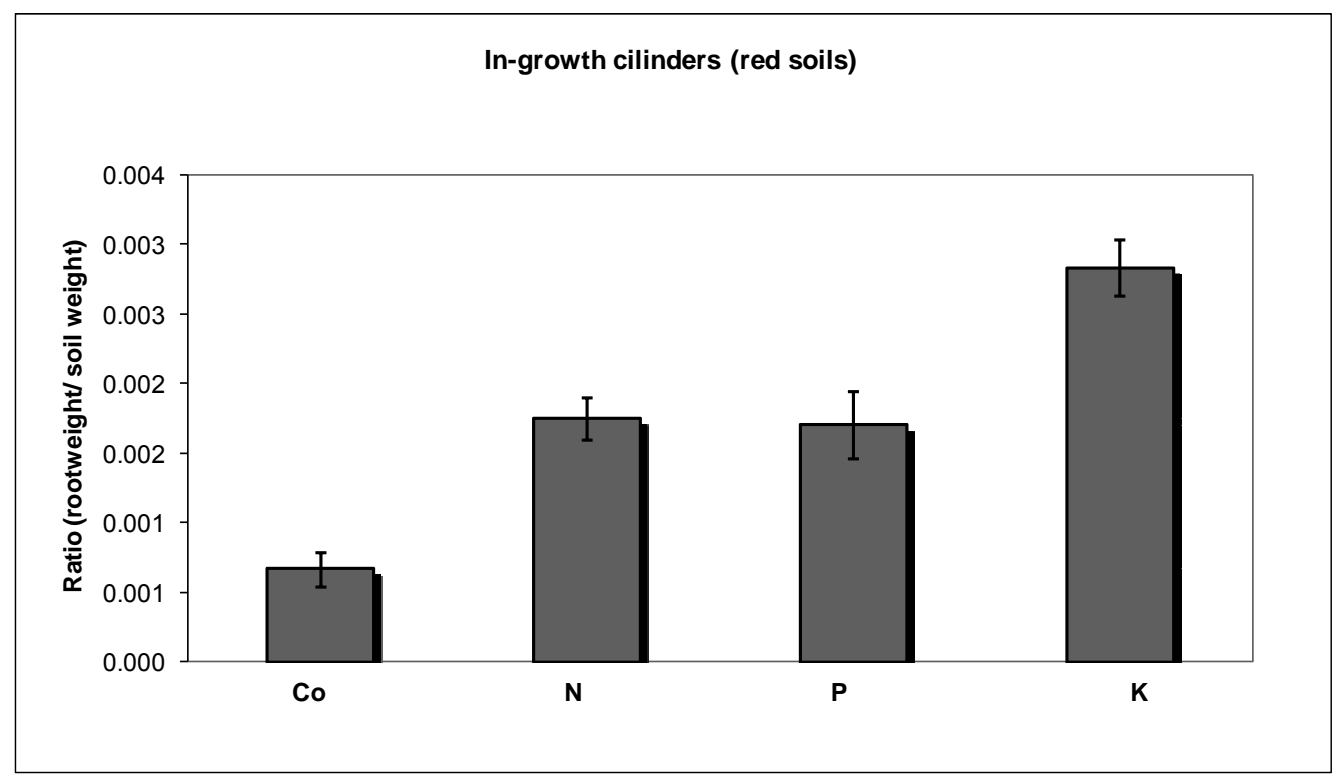

Figure 4-4. Accumulation rates of fine root biomass, in red soils of the dry forest in Northern Yucatan.

The results from the second experiment (establishment of Cordia sp.) show the fertilizer application enhanced the seedling height. Although there were not statistically significant differences, after 6 months, the mean height of seedlings in $\mathrm{P}$ additions were about 6,1 and 3,1 $\mathrm{cm}$ more than the control in black and red soils respectively and $2,8 \mathrm{~cm}$ and $3,5 \mathrm{~cm}$ in $\mathrm{N}$ additions (Table 4-2).

Table 4-2. Multiple range analysis of seedling growth at the end of six months.

\begin{tabular}{cccc}
\hline & \multicolumn{3}{c}{ Average Height Increment (cm)* } \\
\cline { 2 - 4 } SOIL TYPE & Co & Treatment \\
\cline { 2 - 4 } Black & 9.11 & 12.69 & $\mathbf{P}$ \\
\hline St. Desv. & 4.23 & 10.53 & 15.17 \\
Red & n.s & n.s & 10.94 \\
St. Desv. & 7.11 & 9.89 & n.s \\
Significant differences $* *$ & 4.54 & 8.19 & 10.22 \\
Significant differences $* *$ & n.s & n.s & n.s \\
\hline *6-month period & & & \\
$* *$ Fischer $p>0.05$ & & &
\end{tabular}




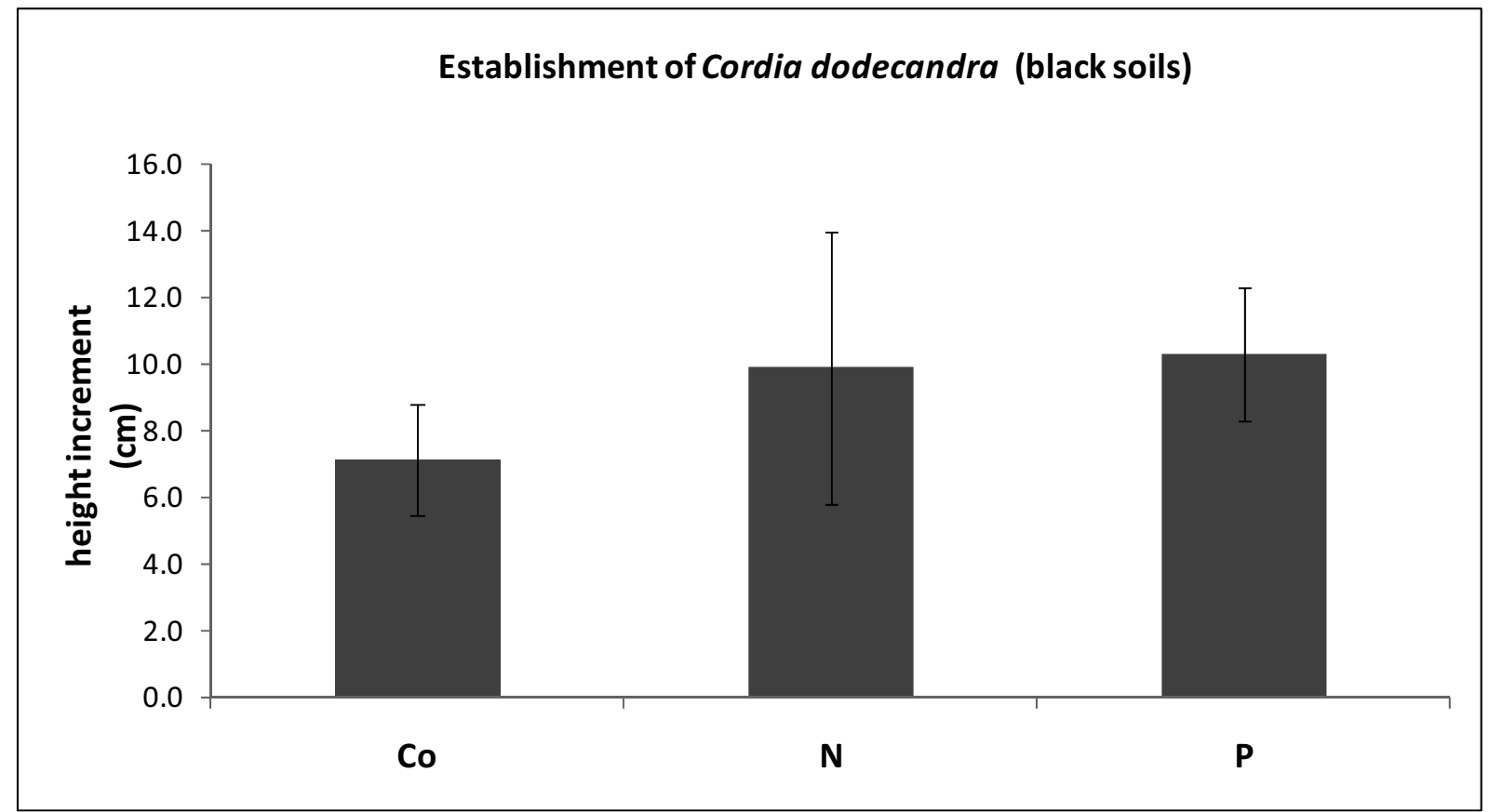

Figure 4-3. Accumulation rates of height increment, in black soils, in Cordia dodecandra plantations, of the dry forest in Northern Yucatan.

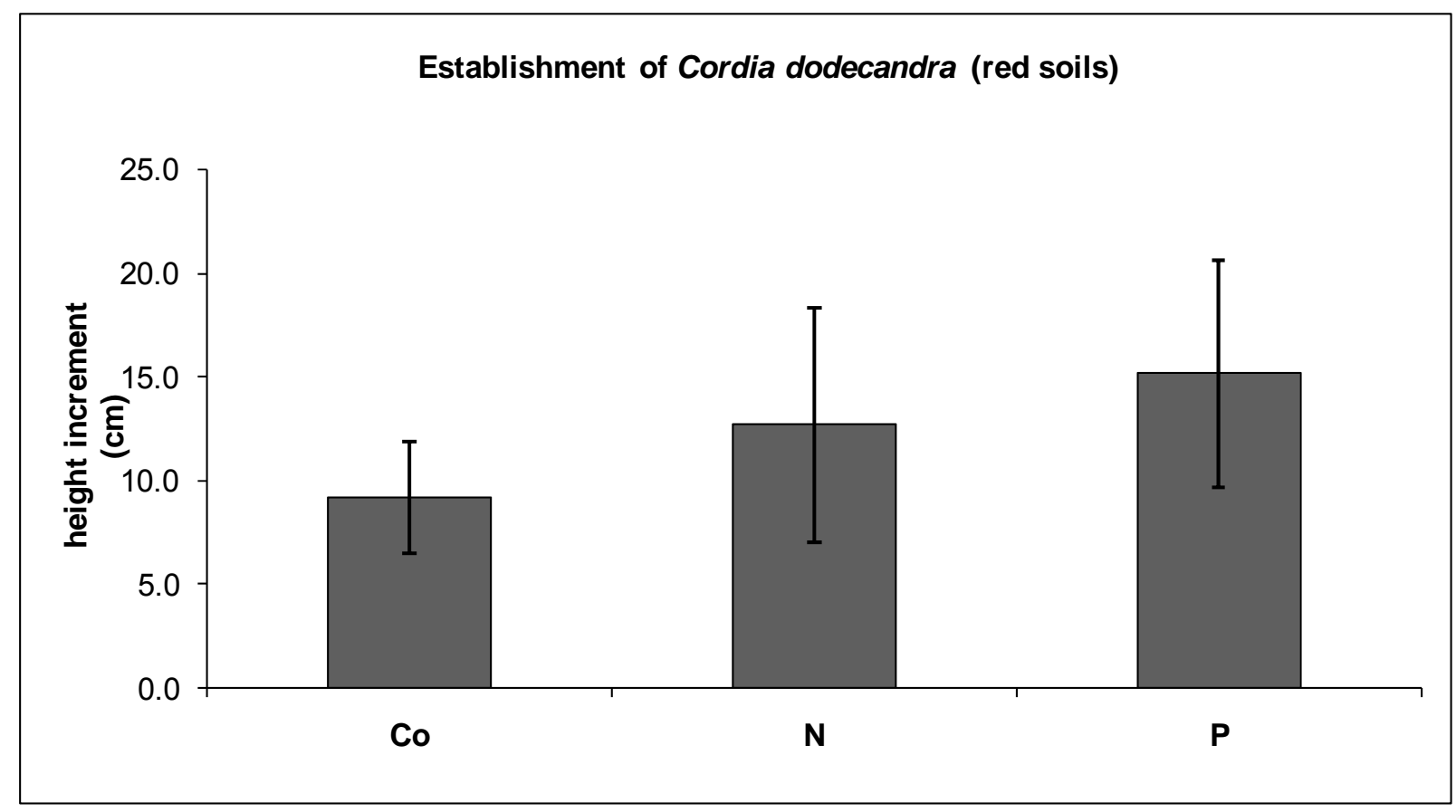

Figure 4-4. Accumulation rates of height increment, in red soils, in Cordia dodecandra plantations, of the dry forest in Northern Yucatan. 


\subsection{CONCLUSIONS}

The fertilizer application demonstrates that roots in a $35 \mathrm{yr}$ forest and seedling in a nursery respond positively to $\mathrm{P}$ and $\mathrm{K}$ additions. Rates of fine root accumulation in the cores varied significantly among treatments $(\mathrm{p}>0.05)$ after 5 months. There was a significant response to $\mathrm{P}$ in both experiments. The effect of the urea fertilizers on the root-ingrowth experiment was not significantly different irrespective of the soil type. Nevertheless, there were considerable differences in $\mathrm{K}$ additions in accumulation rates of fine root biomass, in red and black soils.

These results are consistent with a study which shows that deficiency in available phosphorus had a negative impact on growth of seedlings of $C$. dodecandra (Flachsenberg, 2002). Retarded growth is a typical symptom for $\mathrm{N}$ and $\mathrm{P}$ deficiency (Bergmann, 1993). Limitations in mineral supply of forest trees in central Yucatan, Zech et al. (1991) stated that deficiencies in N, P, Zn and $\mathrm{Mn}$ were responsible for reduced vitality and growth of trees. Though the analysis of available P and organic matter content of the dominant soil groups of Northern Yucatan, red and black soils, did not explain the relative productivity attributed to these soils, it indicated that nutrient availability and soil moisture were closely interrelated (Weisbach et al., 2002). Foliar nutrient contents of $\mathrm{N}, \mathrm{P}$, and base cations can show the availability of these nutrients. Reuter (2005), in an agroforestry set up, found confirmed the extraordinarily high importance of adequate $\mathrm{K}$ supply and water for seedling growth. 


\subsection{REFERENCES}

Arellano Rodriguez, J A; Flores Guido, J S; Tun Garrido, J and Cruz Bojorquez, M M (2003).Etnoflora Yucatense. Nomenclatura, forma de vida, uso, manejo y distribucion de las especies vegetales de la Peninsula de Yucatan. Merida, Mexico, Ed. Universidad Autonoma de Yucatan, Fac. Med. Vet. y Zoot.

Balesdent, J (1991). Estimation du renouvellement du carbone des sols par mesure isotopique 13C. Precision, risque de biais / Quantitative Estimate of Soil C Turnoverby 13C Measurements. Precision, Possible Biases. Cah. Orstom, serie Pedologie 26(4): 315-326.

Balesdent, J; Besnard, E; Arrouays, D and Chenu, C (1998). The Dynamics of Carbon in Particle-Size Fractions of Soil in a Forest-Cultivation Sequence. Plant and Soil 201:49-57.

Balesdent, J and Mariotti, A (1987). Natural 13C Abundance as a Tracer for Studies of Soil Organic Matter Dynamics. Soil Biol. Biochem. 19(1): 25-30.

Balesdent, J; Wagner, G H and Mariotti, A (1988). Soil Organic Matter Turnover in Longterm Field Experiments as Revealed by Carbon-13 Natural Abundance. Soil Sci. Soc. Am. J. 52: 118124.

Benjamin, T J; Montanez, J J; Jimenez-Osornio, J J and Gillespie, A R (2001). Carbon, Water and Nutrient Flux in Maya Homegardens in the Yucatan Peninsula of Mexico. Agroforestry Systems 53: 103-111.

Bird, M; Kracht, O; Derrien, D and Zhou, Y (2003). The Effect of Soil Texture and Roots on the Stable Carbon Isotope Composition of Soil Organic Carbon. Aust. J. Soil. Sci. 41:77-94.

Bonde, T; Christensen, B T and Cerri, C C (1992). Dynamics of Soil Organic Matter as Reflected by Natural 13C Abundance in Particle Size Fractions of Forested and Cultivated Oxisols. Soil Biol. Biochem. 24(3): 275-277. 
C. Ruiz, C. Kleinn and R. Olschewski. 2003. Land cover analysis and afforestation options for mitigation of climate change in Lowlands of Bolivia. IUFRO conference on Applied Forest Ecological Experiments.Davos, Switzerland.

Cambardella, C A and Elliott, E T (1992). Particulate Soil Organic-Matter Changes across a Grassland Cultivaton Sequence. Soil Sci. Soc. Am. J. 56: 777-783.

Cambardella, C A and Elliott, E T (1993). Carbon and Nitrogen Distribution in Aggregates from Cultivatedand Native Grassland Soils. Soil Sci. Soc. Am. J. 57: 1071-1076.

Cambardella, C A and Elliott, E T (1994). Carbon and Nitrogen Dynamics of Soil Organic Matter Fractions from Cultivated Grassland Soils. Soil Sci. Soc. Am. J. 58: 123-130.

Clough, A and Skjemstad, J O (2000). Physical and Chemical Protection of Soil Organic Carbon in Three Agricultural Soils with Different Contents of Calcium Carbonate. Aust. J. Soil. Sci. 38: 1005-1016.

Duch Gary, J (1988). La Conformacion Territorial del Estado de Yucatan. Mexico, Universidad Autonoma Chapingo. 427 pp.

Duchaufour, P (1976). Dynamics of Organic Matter in Soils of Temperate Regions: Its Action on Pedogenesis. Geoderma 15: 31-40.

Echenique, J. (2005). Natural_ 13C Signals and Soil Organic Carbon Turnover in Calcareous Soils of Yucatan, Mexico. M.Sc. Thesis in Tropical and International Agriculture at the GeorgAugust-University.

Ehleringer, J R; Buchmann, N and Flanagan, L B (2000). Carbon Isotope Ratios in Belowground Carbon Cycle Processes. Ecological Applications 10(2): 412-422. 
Garcia-Montiel, D C and Neill, C (2000). Soil Phosphorus Transformations Following Clearing for Pasture in the Brazilian Amazon. Soil Sci. Soc. Am. J. 64: 1792-1804.

Girardin, C and Mariotti, A (1991). Analyse Isotopique du 13C en Abondance Naturelle dans le Carbone Organique: un Susteme Automatique Avec Robot Preparateur / Automated Analysis System for 13C Natural Abundance Measurement in Organic Carbon. Cah. Orstom, serie Pedologie XXVI(4): 371-380.

González-Iturbe Ahumada, J A; Olmsted, I and Tun-Dzul, F (2001). Tropical Dry Forest After Long Term Henequen (Sisal, Agave fourcroydes Lem.) Plantation in Northern Yucatan, Mexico. Forest Ecology and Management 5736: 1-16.

Graefe, S (2003). Crop and Soil Variability in Traditional and Modern Mayan Maize Cultivation of Yucatan, Mexico. Journal of Agriculture and Rural Development in the Tropics and Subtropics, kassel university press GmbH Beiheft Nr. 75.

J.A. Gonzales-Iturbe Ahumada, I. Olmsted, F. Tun-Dzul. 2001. Tropical dry forest recovery after long term Henequen (sisal, Agave fourcroydes Lem.) plantation in northern Yucatan, Mexico. Forest Ecology and Management 5736 (2001) 1-16.

J.J. Jimenez Osornio, B. Luckman, A. Medina, E. Noellemeyer, F. Roig, H. Tiessen and J. Villanueva. 2003. Exploratory dendrochronological work on trees in the land use system of Yucatan. Progress report from a cooperative initiative between IAI-CRN 001 and 003.

Harris, D; Horwarth, W and van Kessel, C (2001). Acid Fumigation of Soils to Remove Carbonates Prior to Total Organic Carbon or Carbon-13 Isotopic Analysis. Soil Sci. Soc. Am. J. 65: $1853-1856$.

INEGI (2005). Sitio del INEGI en Internet. http://www.inegi.gob.mx. [22-02-05]. Jastrow, J D (1996). Soil Aggregate Formation and the Accrual of particulate and Mineral- Associated Organic Matter. Soil Biol. Biochem. 28: 665-676. 
I. Peter and J. Lehman (2000). Pruning effects on root distribution and nutrient dynamics in an acacia hedgerow planting in northern Kenya Institute of Soil Science and Soil Geography, University of Bayreuth, 95440 Bayreuth, Germany Agroforestry Systems 50: 59-75.

Jastrow, J D; Boutton, T W and Miller, R M (1996). Carbon Dynamics of Aggregate- Associated Organic Matter Estimated by Carbon-13 Natural Abundance. Soil Sci. Soc. Am. J. 60: 801-807.

Mariotti, A (1991). Le carbone 13 en abondance naturelle, traceur de la dynamique de la matiere organique des sols et de l'evolution des paleoenvironments continentaux / 13C Natural Abundance, Tracer of Soil Organic Matter Dynamics and of Continental Paleoecosystems Changes. Cah. Orstom, serie Pedologie 26(4): 299-313.

Martin, A; Mariotti, A; Balesdent, J; Lavalle, P and Vuattoux, R (1990). Estimate of Organic Matter Turnover Rate in a Savanna Soil by 13C Natural Abundance Measurements. Soil Biol. Biochem. 22(4): 517-523.

Nissenbaum, A and Schallinger, K M (1974). The Distribution of the Stable Isotope (13C/12C) in Fractions of Soil Organic Matter. Geoderma 11(2): 137-145.

Roscoe, R; Buurman, P; Velthorst, E J and Vasconcellos, C A (2001). Soil Organic Matter Dynamics in Density and Particle Size Fractions as Revealed by the $13 \mathrm{C} / 12 \mathrm{C}$ Isotopic Ratio in a Cerrado's Oxisol. Geoderma 104(3-4): 185-202.

Shang, C and Tiessen, H (1997). Organic Matter Lability in a Tropical Oxisol: Evidence from Shifthing Cultivation, Chemical Oxidation, Particle size, Density, and Magnetic Fractionations. Soil Science 162(11): 795-807.

Shang, C and Tiessen, H (1998). Organic Matter Stabilization in Two Semiarid Soils: Size, Density, and Magnetic Separations. Soil Sci. Soc. Am. J. 62: 1247-1257. 
Shang, C and Tiessen, H (2000). Carbon Turnover and Carbon-13 Natural Abundance in Organo-Mineral Fractions of a Tropical Dry Forest Soil under Cultivation. Soil Sci. Soc. Am. J. 64: 2149-2155.

Shang, C and Tiessen, H (2003). Soil Organic C Sequestration and Stabilization in Karstic Soils of Yucatan. Biogeochemistry 62: 177-196.

Six, J; Bossuyt, H; Degryze, S and Denef, K (2004). A History of Research on the Link Between (Micro)Aggregates, Soil Biota, and Soil Organic Matter Dynamincs. Soil and Tillage Research 79: 7-31.

Six, J; Conant, R T; Paul, E A and Paustian, K (2002). Stabilization Mechanisms of Soil Organic Matter: Implications for C-Saturation of Soils. Plant and Soil 241: 155-176.

Six, J; Elliott, E T and Paustian, K (1999). Aggregate and Soil Organic Matter Dynamics under Conventional and No-Tillage Systems. Soil Sci. Soc. Am. J. 63: 1350-1358.

Six, J and Jastrow, J D (2002). Organic Matter Turnover. Encyclopedia of Soil Science, Marcel Dekker, Inc.: 936-942.

Solomon, D; Fritzsche, F; Lehmann, J; Tekalign, M and Zech, W (2002). Soil Organic Matter Dynamics in the Subhumid Agroecosystems of the Ethiopian Highlands: Evidence From Natural 13C Abundance and Particle-Size Fractionation. Soil Sci. Soc. Am. J.66: 969-978.

Tiessen, H; Cuevas, E and Chacon, P (1994). The Role of Soil Organic Matter in Sustaining Soil Fertility. Nature 371: 783-785.

Tiessen, H; Cuevas, E and Salcedo, H I (1998a). Organic Matter Stability and Nutrient Availability under Temperate and Tropical Conditions. Advances in GeoEcology 31: 415-422. 
Tiessen, H; Feller, C; Sampaio, E V S B and Garin, P (1998b). Carbon Sequestration and Turnover in Semiarid Savannas and Dry Forest. Climatic Change 40: 105-117.

Tiessen, H and Stewart, J W B (1983). Particle-size Fractions and their Use in Studies of Soil Organic Matter: II. Cultivation Effects on Organic Matter Composition in Size Fractions. Soil Sci. Soc. Am. J. 47: 509-514.

Tisdall, J M and Oades, J M (1982). Organic Matter and Water-Stable Aggregates in Soils. J. Soil Sci. 33: 141-163.

Veldkamp, E (1994). Organic Carbon Turnover in Three Tropical Soils under Pasture after Deforestation. Soil Sci. Soc. Am. J. 58: 175-180.

Veldkamp, E and Weitz, A M (1994). Uncertainty Analysis of _ 13C Method in Soil Organic Matter Studies. Soil Biol. Biochem. 26(2): 153-160.

Vitorello, V A; Cerri, C C; Andreux, C; Feller, C and Victoria, R L (1989). Organic Matter and Natural Carbon-13 Distribution in Forested and Cultivated Oxisols. Soil Sci. Soc. Am. J. 53: 773-778.

Weisbach, C; Tiessen, H and Jimenez-Osornio, J J (2002). Soil Fertility During Shifting Cultivation in the Tropical Karst Soils of Yucatan. Agronomie 22: 253-263.

M. Worbes, R. Staschel, A. Roloff and W.J. Junk. 2003. Tree Ring Analysis Reveals Age Structure, Dynamics and Wood Production of a Natural Forest Stand in Cameroon: Forest Ecology and Management. 173 (2003): 105-123. 


\section{CHAPTER 5: CONCLUSIONS}

\section{General conclusions}

- The basal area, estimated volume, and TAGB, and species richness increased with increasing forest age while frequency of trees decreases.

- Forest floor biomass increased with age to reach a mean biomass of 20-24 ton/ha over 50 years. Higher age should enhance decomposition, leading to lower forestfloor biomass if litter production were to remain constant.

- Pools of total $\mathrm{C}$ and $\mathrm{N}$ in mineral soils increased with increasing forest age. Although there are not conclusive results, $\mathrm{K}$ could be a limiting factor for forest growth.

- Tree ring analysis can serve as a measure of forest production and climatic stress in Yucatan.

- The parallel variation value (Glk.-value), as a measure for the similarity a tree ring series, indicates a good relation between annual growth and annual precipitation.

- Stem-Volume in mature secondary forests $>45 \mathrm{yrs}$ ranged from 56 to $95 \mathrm{~m}^{3} / \mathrm{ha}$. A single tree of Piscidia piscipula provides a volume of approximately $0.8 \mathrm{~m}^{3}$ after $45 \mathrm{yr}$.

- Ingrowth- cilinders and nursery experiments show $\mathrm{K}$ and $\mathrm{P}$ fertilizers may have positive impacts in forest growth. 


\section{Implications}

Ecosystems are not static but change constantly. We learnt in Part 1, which in Northern Yucatan, huge areas of abandoned sisal plantations, now assigned to the communities, require management strategies that take into account the high spatial variability of soil, the lack of surface water, and the generation of income for farmers. However, the character of these secondary forest ecosystems is largely a result of the interplay between disturbance and succession forces.

We also learnt, from the vegetation analysis of Part 2, the structure and species composition of these forest successions. Succession processes, like occurred in Northern Yucatan after abandonment of sisal plantations, open up growing space that can be invaded or re-colonized by pioneer species. Our results showed that the total height and basal area increased with stand age, indicating that secondary forests rapidly attain a forest structure similar to mature forests after 35 years. However, ddisturbances factors can be powerful forces shaping forests and landscapes, and it's important that decision makers appreciate the historical forces that have formed the Yucatec secondary forest of today. Different stands were delineated where distinct differences in species composition, age or structure. Structure and function in secondary forests (biomass, litter production, forest floor mass and critical soil properties) are strongly influenced by the age of the stand. The structure of stands was described in qualitative and quantitative terms. Quantitative measures described in part 2, were the species mixture, the age distribution, and the size of living and dead plants or their parts (stem diameters, height, leaf area, coarse woody debris, etc.). In our results, the correspondence analysis indicated that species composition also varies with stand age. However, our results showed that these forests have low values of species richness and structure attributes in relation with other tropical dry forest of Mexico and the world.

In part 3, our forest inventory and tree ring analysis analyzed growth rates of secondary forests along a chronosequence. We determined that secondary forests in Northern Yucatan have the potential to produce an average amount of timber of $0,087 \mathrm{~m}^{3} /$ tree over 
50 years old for timber or medium amount of firewood $\left(2,65 \mathrm{~m}^{3} / \mathrm{ha} / \mathrm{yr}\right)$. Although these potential may be limited for industrial wood production, previous experiences in similar regions demonstrated important production of fuel wood is possible and that silvicultural strategies could be identified to stimulate the production of commercial timber species in this forest fallows, such as liberation thinning, enrichment plantings and refining. However, sustainable management systems, rates of natural regeneration, the role of enrichment planting or improved fallows, and the forestry potential of agroforestry practices need to be further investigated.

The study of nutrient dynamics in the region provides important clues about the regenerative capacity of the forests. The soil analyses at different stand age reveal that the overall fertility may be lower in young secondary forest. Unlike the other indices of fertility such as $\mathrm{C}$ and $\mathrm{N}, \mathrm{K}$ levels were significantly higher in young forest which may indicate translocation functions of plants when $\mathrm{K}$ becomes limiting factor. Litter production increased consistently with age. Interaction between the forest age and soil type was a determining factor for $\mathrm{OC}$ and total $\mathrm{N}$ contents in these ecosystems. Red soils had less OC and $\mathrm{N}$ compared to the black ones. These differences between both soils were strongly marked by their mineralogical properties. This assessment of the nutritional of these soils contributes to improve soil management and to understand the role of forest fallow in sustaining quality of the ecosystem. Suitable and sensitive techniques, which combine the influence of climatic factors and biochemical processes in the soil, permit a better understanding of these semiarid ecosystems.

The root-ingrowth experiment of part 4 , showed a positive effect of $K$ addition in root growth and a moderate effect of $\mathrm{P}$, especially in red soils, with no effect of $\mathrm{N}$ or Co interaction. The results from the second experiment, using Cordia dodecandra seedlings in a nursery, showed the fertilizer application enhanced the seedling height after 6 months.

Although forest age seems to influence nutrient cycling positively, especially in soil $\mathrm{N}$, its greatest effect was to alter litter production and aboveground biomass. Water 
limitation seems to be the predominant environmental factor limiting ecosystem processes in these dry forests. Sampling along this forest fallow has allowed the evaluation of broad stand-stages of ecosystem processes.

Landuse decision makers need to be aware of the ecosystem to recover following several years of sisal plantations. Ecosystem managers therefore need to have a thorough understanding of the succession, because it enables them to work natural processes where this is possible, it encourages the creation of stable ecosystems, and allows the realistic assessment of management objectives.

\section{Identification of key areas for future research}

How does what we know and may learn about natural forest dynamics and ecosystem processes affect management practices? An understanding of natural forest dynamics is a prerequisite for sustainable forest management.

The findings and topics exposed in this chapter illustrate the importance of studying secondary succession in tropical environments.

Different regeneration patterns occur depending on land management following deforestation. Although it is clear that secondary vegetation will not preserve the total biodiversity of mature forests, it is also clear that it plays an important role in the Northern Yucatan landscape structure and function.

The role of species composition within the different stages of regrowth is important to understand to estimate production potential and ecosystem quality. Studies have shown that disturbance from slash-and-burn agriculture affects species composition much more than stand structure and biomass (Uhl 1987). Vieira et al. (1996) have also pointed out that even after 40 years of recovery; richness is less than half of a primary forest. 
Although such an issue is of central relevance to the maintenance of local and regional biodiversity, we are far from being able to differentiate distinct tropical forest communities based on species composition when using satellite data. Current applications can only recognize different structural patterns and processes.

The ecological functions of secondary forests at local and regional scales have just recently been investigated. Besides maintaining one-third of the native species, their role in carbon sequestration seems to be even more important (Vieira et al. 1996). Furthermore, successional vegetation re-evaporates an important part of the rainfall input in spite of the marked seasonal distribution of rainfall (Holscher et al. 1997). Possible regional climatic changes due to deforestation may be less severe in areas where woody secondary vegetation plays an important role in land cover.

At the local scale, the stages of secondary succession are directly associated with cycles of production and abandonment. Slash and burn clearing, cropping, and fallowing correspond to different phases within these cycles and depend on decision-making processes among the landowners. In this sense, monitoring the outcomes in terms of vegetation structure and LULC may also provide information about actions being taken by farmers. The study of LULC dynamics, and its fundamental importance to the understanding of general patterns of landscape transformation. 


\section{SUMMARY}

Secondary forests in large areas of Semiarid Americas play a vital role in the maintenance of land quality and are also important for the community. The total benefits of ecosystem services provided by forest fallows and the potential for forest production have not been evaluated, largely because forest productivity under secondary land cover has rarely been measured with an eye to marketable products.

This study evaluates the productivity of forest fallows derived from agricultural activities (Henequen plantations; Agave fourcroydes Lem) in a climatically vulnerable semiarid region in Northern Yucatan. We explored options for improved landuse management in secondary forest and measured nutrient budgets in soils and vegetation and use tree-ring analysis to predict tree productivity in fallow vegetation of different succession states. Floristic composition, species richness, and diversity of the seasonally was described. We sampled eighteen $1,000 \mathrm{~m}^{2}$ sites and recorded species and $\mathrm{dbh}$ of trees and shrubs of trees $>1 \mathrm{~cm} \mathrm{dbh}$. Cross dating techniques were used to identify correlation between tree growth and climatic patterns. Furthermore, root-ingrowth trials were established to identify limiting factors in soils. To validate these results, we conducted a trial with Cordia dodecandra to identify limiting $\mathrm{P}$ and $\mathrm{N}$ on black and red soils at a nursery stage.

Our results showed that secondary forests rapidly attain a forest structure similar to mature forests after 35 years. The results of the correspondence analysis indicated that species composition varies with stand age. In the sampling sites, data from 715 individuals $(>8 \mathrm{~cm} \mathrm{dbh})$ and 708 individual $(<8 \mathrm{~cm}$ and $>1 \mathrm{~cm} \mathrm{dbh})$ were recorded, representing 63 woody species, 56 genera, and individuals Gymnopodium (Polygonaceae) and Bursera (Birseracea) were the most common species. Species richness among sites ranged from 43-63. These results indicate that these forests have low values of species richness and structure attributes in relation with other tropical dry forest of Mexico and the world. 
The soil analyses at different stand age reveal that the overall fertility may be lower in young secondary forest. Unlike the other indices of fertility, K levels were significantly higher in young forest which may indicate translocation functions of plants when $\mathrm{K}$ becomes limiting factor. Litter production increased consistently with age. Interaction between the forest age and soil type was a determining factor for $\mathrm{OC}$ and total $\mathrm{N}$ contents in these ecosystems. Red soils had less OC and $\mathrm{N}$ compared to the black ones. These differences between both soils were strongly marked by their mineralogical properties.

The root-ingrowth experiment showed a significant effect of $\mathrm{K}$ addition, a moderate effect of $\mathrm{P}$, especially in red soils, with no effect of $\mathrm{N}$ or $\mathrm{Co}$ interaction. The results from the second experiment (using Cordia dodecandra seedlings in a nursery) show the fertilizer application enhanced the seedling height after 6 months.

Forest inventory and tree ring analysis show that these secondary forests have the potential to produce an average amount of timber of about $0,087 \mathrm{~m}^{3} /$ tree over 50 years or an average amount of firewood $2,6 \mathrm{~m}^{3} / \mathrm{ha} / \mathrm{yr}$. Although these potential may be limited for industrial wood production, previous experiences in similar regions demonstrated that silvicultural strategies could be identified to stimulate the production of commercial timber species in this forest fallows, such as liberation thinning, enrichment plantings and refining. 


\section{ZUSAMMENFASSUNG}

Sekundärwälder spielen in großen Bereichen der halbtrockenen Gebiete Nord-, Mittel-, und Südamerikas eine wesentliche Rolle in der Erhaltung der Ökosystemqualität und sind ausserdem wichtig für die ansässige Bevölkerung.

Diese Studie bewertet die Produktivität von landwirtschaftlichen Aktivitäten (SisalPlantagen; Agave fourcroydes Lem) in Waldbrachen in einer klimatisch sensiblen halbtrockenen Region im Norden Yucatans, Mexiko. Wir untersuchten Optionen für ein verbessertes Landnutzungsmanagement in Sekundärwäldern. Nährstoffbudgets von Böden und Vegetation wurden gemessen und Jahresringe analysiert, um die Produktivität von Baumwachstum auf Brachen verschiedener Stadien vorhersagen zu können.

Vielfalt und Zusammensetzung der Flora wurden beschrieben, und Jahresringchronologien wurden genutzt, um Zusammenhänge zwischen Baumwachstum und Klimabedingungen $\mathrm{zu}$ identifizieren. Desweiteren wurde die "ingrowth core ${ }^{\star a}$ Methode zur Messung der Wurzelproduktion angewendet, um die limitierenden Faktoren der Böden zu identifizieren. Mit Cordia dodecandra wurden die Ergebnisse bezüglich Pund N-Mängeln validiert.

Unsere Ergbnisse zeigten, das die Strukturen der Sekundärwälder sehr rasch denen von 35-jährigen Wäldern ähnlich werden. Die Ergebnisse der Korrespondenzanalyse deuten darauf hin, daß die Artenvielfalt mit dem Alter der Bestände variiert. In den Probegebieten wurden Daten von 715 Bäumen mit über 8cm BHD und von 708 Bäumen zwischen 1 und 8 Zentimetern gesammelt. Diese representierten 63 Baumarten aus 56 Genera und einzelnen anderen Vertreter. Gymnopodium (Polygonaceae) und Bursera (Burseracea) waren die am häufigsten vorkommenden Arten.

Bodenanalysen aus unterschiedlich alten Beständen offenbarten, daß die Bodenfruchtbarkeit in jüngeren sekundären Wäldern niedriger ist. Lediglich die K- 
Gehalte sind in jungen Wäldern signifikant höher. Dies könnte auf translokationene in den Pflanzen in den Fällen hinweisen, in denen $\mathrm{K}$ zum limitierenden Faktor wird.

Die Laubdeckschicht nimmt mit dem Alter kontinuierlich zu. Mineralogische Messungen machten deutlich, daß rote Böden im Vergleich zu schwarzen über weniger organische Kohlenstoffe und $\mathrm{N}$ verfügen.

Das root-ingrowth Experiment reagierte signifikant auf K-Zufuhr, moderat auf PBeeinflussung (insbesondere in roten Böden), und zeigte keine Effekte auf $\mathrm{N}$ oder $\mathrm{C}$ Wechselwirkungen.

Waldinventur und Wachstumsringanalyse zeigen, daß die Sekundärwälder das Potential zur Produktion einer durchschnittlichen Nutzholzmenge von $0,087 \mathrm{~m}^{3} /$ Baum im Alter 50 haben, beziehungsweise eine durchschnittliche Menge Feuerholz von 2,6 $\mathrm{m}^{3} / \mathrm{ha} / \mathrm{Jahr}$ produzieren können.

Auch wenn das Potential für die industrielle Produktion auf diesen Bracheflächen jetzt begrenzt sein mag, können waldbauliche Strategien wie Läuterungshiebe, Durchforstungen und Anreicherungspflanzungen die Produktion kommerziell nutzbarer Arten und Volumen stimulieren 


\section{ACKNOWLEDGMENTS}

I would like to express my deep and sincere gratitude to my supervisor Prof. Dr. Holm Tiessen. His passion for science is contagious and motivating. I am very grateful to my co-supervisors Prof. Dr. M. Worbes (Head of the Institute in the Tropics and Subtropics, Uni-Goettingen) and to Prof. Dr. Juan Jimenez Osornio (Universidad Autonoma of Yucatan, Mexico), for their cooperation throughout the fieldwork, presentation and publication processes of this work.

I want to express my deep gratitude to the members of the IAT Institute in Goettingen: Ute Ronsöhr, Esther Fichtler, Dr. Ronald Kühne, Birgit Bode, Frau Friedrich and Thomas. Without their encouragement it would have been impossible for me to complete this work.

In Mexico, to all Staff members of PROTROPICO for their friendship, hospitality and collaboration. I am very grateful to Don Alfonso Castillo and his team, Rocio Ruenes (and her "cuclillos"), Erika Pérez, Gerardo Ceballos, Paty, Mr. Ku, Manja, Roxana, thanks a lot.

I wish to express my warm and sincere thanks to the staff members and colleagues of the IPAG Program and CeTSAF, Professor Dr. Luecke, Dr. Muuss, Prof. Kleinn, Prof. Dr. Wollny, Mrs. Thinngard, Mrs. Lunderstädt, Mrs. Voos, Dr. Heinzemann, Rolando Hernandez and to my "yucatec" colleagues Jero, Martina, Edith and Adriana for their valuable help. To Matias Fecht and Marion Karmann from FSC. Thank you all for your guidance and support.

The financial support of the Interamerican Institute for Global Change Research (IAI), IPAG at the University of Goettingen, and UNESCO is gratefully acknowledged.

My sincere thanks to my family: Paula, Francisco and Ignacio, for being with me unconditionally, for their love, patience, and enthusiasm along this journey. 


\section{CURRICULUM VITAE}

\section{PERSONAL DATA}

NAME

MAJOR

NATIONALITY

E-MAIL

MEMBERSHIPS: $\quad$ RECALL -Research Alumni Network Germany \& Latin America FSC: Voluntary member.

IUFRO: Voluntary member.

\section{ACADEMIC RECORDS}

UNIVERSITY DEGREE

POSGRADUATE DIPLOMA

POSTGRADUATE DEGREE
:Forest Engineer. University of Concepcion. Concepción - Chile, 92 - 97. Approved With Distinction. (Mario Puentes Espil Award 1997).

:Environmental Analysis \& Management. Europe-Latin America International Research Centre for Environmental Sciences (EULA), Concepción - Chile. February-December 1997.

Major in Project Management. ADEN Business School - Stetson University (2006). www.aden.org

:M.Sc. in Tropical and Subtropical Forestry. Georg-August University of Goettingen - Germany. IUFRO AWARD for Excellence in Forestry $\underline{\text { Sciences. }}$

\section{PROFESSIONAL CAREER}

$\underline{2000 / 01-2005 / 07}$.Environmental Specialist - HSE, ISO 14001. Empresa Petrolera Andina-REPSOL YPF E\&P Bolivia.

1999 -2001. Consultant “Project GCP/RLA/133/EC” European Union - FAO (Santiago, Chile) \& Forest Superintendence (Bolivia): ITTO - Siforbol Rev.1(Bolivia);

1998 - 1999. Responsible of the "Eucalyptus Growth Simulation Project "CHILE FOUNDATION: www.fundch.cl 